\title{
The pharciceratid ammonoids from the Roteisenstein Formation of Dillenburg (Cephalopoda, Ammonoidea)
}

\author{
Dieter KORN ${ }^{1, *} \&$ Jürgen BOCKWINKEL ${ }^{2}$ \\ ${ }^{1}$ Museum für Naturkunde, Leibniz-Institut für Evolutions- und Biodiversitätsforschung, \\ Invalidenstraße 43, 10115 Berlin, Germany. \\ ${ }^{2}$ Dechant-Fein-Straße 22, 51375 Leverkusen, Germany. \\ *Corresponding author: dieter.korn@mfn.berlin \\ 2Email: jbockwinkel@t-online.de \\ ${ }^{1}$ urn:lsid:zoobank.org:author:286CA4F3-7EBC-4AEF-A66A-B2508D001367 \\ ${ }^{2}$ urn:lsid:zoobank.org:author:F7FE7EEA-B678-4FEE-879C-8C429F66BF3A
}

\begin{abstract}
The ammonoids of the suborder Pharciceratina from the Red Ironstone Formation of the area around Dillenburg (eastern Rhenish Mountains) are revised, mainly based on historical collections stored in the Museum für Naturkunde, Berlin. The genus Evopharciceras gen. nov. and the following species are newly described: Maenioceras ornatum sp. nov., Pharciceras beyrichi sp. nov., Pharciceras kruegeri sp. nov., Pharciceras ferrum sp. nov., Evopharciceras formosum gen. et sp. nov., Extropharciceras metallicum sp. nov., Lunupharciceras kochi sp. nov., Stenopharciceras lotzi sp. nov., Pluripharciceras ahlburgi sp. nov. and Sandbergeroceras archiaci sp. nov. Neotypes are proposed for the species Extropharciceras becheri (von Buch, 1832) and Sandbergeroceras costatum (d'Archiac \& de Verneuil, 1842). The stratigraphic distribution of the genera is discussed; they are assigned to three assemblages: (1) Maenioceras terebratum Zone (early Givetian; two species), (2) Pseudoprobeloceras pernai Zone (latest Givetian; fifteen species) and (3) Sandbergeroceras costatum Zone (early Frasnian; three species).
\end{abstract}

Keywords. Ammonoidea, Middle Devonian, Late Devonian, Rhenish Mountains, taxonomy.

Korn D. \& Bockwinkel J. 2021. The pharciceratid ammonoids from the Roteisenstein Formation of Dillenburg (Cephalopoda, Ammonoidea). European Journal of Taxonomy 771: 1-79.

https://doi.org/10.5852/ejt.2021.771.1503

\section{Introduction}

The study of late Givetian ammonoid assemblages is closely linked to the Roteisenstein (Red Ironstone) Formation in the Dillenburg and Oberscheld district at the eastern margin of the Rhenish Mountains. Almost all Late Givetian ammonoid species newly described before 1960 originate from the Dillenburg area, and most of these specimens were collected in the course of intensive underground ironstone mining. While many specimens from this mining area were distributed to various museums at the end of the $19^{\text {th }}$ and beginning of the $20^{\text {th }}$ century, there is hardly any new material since the decline in mining activities that led to the demise of mining in the 1970s (Georg et al. 1985; Stoppel 1988). Therefore, 
the revision of the Central European Late Givetian ammonoid species is entirely based on historical collections.

From the second half of the $20^{\text {th }}$ century, diverse late Givetian ammonoid assemblages have been discovered in the Anti-Atlas of Morocco (Petter 1959; Bensaïd 1974; Bockwinkel et al. 2009, 2013a, $2015,2017)$. This material is much better preserved than the Rhenish material and allows a substantially better understanding of the morphological spectrum. Currently, about 40 ammonoid species are known from the Moroccan localities. The Moroccan material consists of both calcareous specimens and limonitic internal moulds.

In the following, we provide a re-description of the pharciceratid ammonoid material available in the collections of the Museum für Naturkunde, Berlin. The purpose of this description is to make the material of the classical sites from the Dillenburg area known in order to support a supra-regional comparison of time-equivalent assemblages.

\section{The Red Ironstone of the Dillenburg district}

The Red Ironstone of Dillenburg has been mined over a period of more than 2000 years; iron ores were already mined and smelted in the La Tène period in the vicinity of Oberscheld (Jockenhövel \& Willms 1993). The iron ore brought great economic importance to the region around Dillenburg for centuries (Frohwein 1885; Georg et al. 1985); as early as the beginning of the $17^{\text {th }}$ century, hammer mills worked in the area around Oberscheld (Becher 1789).

The Ironstone is an exhalative-synsedimentary formation of haematite ores (so-called Lahn-Dill Type), which originated from ascending hydrothermal fluids connected with basaltic volcanism. It overlies the so-called Schalstein and Mandelstein (= volcanic tuffites) and is in turn overlain by either Late Devonian shales or cephalopod limestones. The red ironstone ore deposit has been described as a succession of several layers up to 4 metres thick, which may be distributed over a sequence of layers up to 50 metres thick (e.g., Koch 1858; Frech 1888; Lotz 1902; Lotz in Kayser 1907a, 1907b; Kegel 1934a, 1934b, 1934c; Lippert \& Hentschel in Lippert et al. 1970; Lippert \& Nesbor in Bender et al. 1997). The siliceous iron ores occur in varying concentrations; they are often more or less intensively mineralised limestones that still show the carbonate microfacies and allow the extraction of the macrofossils.

An early geological explanation of the red ironstone ore was given by Lotz (in Kayser 1907a, 1907b), at that time on the basis of numerous accessible subsurface outcrops. He already pointed out the complicated bedding conditions including shallow overthrusts, that were an obstacle for creating a clear stratigraphic classification of the layers. He accepted the hypothesis expressed shortly before by Harbort (1903) that the iron ores were primary in nature and related to diabase volcanism and postulated a formation caused by hot springs rich in carbon dioxide and iron in the aftermath of volcanic activity.

Lotz has already clearly shown that there are several layers of red ironstone and that the lithology of the individual layers can be very different. He distinguished between siliceous haematite ores and the so-called "Flußeisenstein"; the latter is rather to be regarded as mineralised limestone and yielded the most and best-preserved fossils.

It has long been known that the red ironstone shows considerable lateral changes in thickness. The thickness depends on the topography of the seabed; on submarine sills it is thicker and more enriched in iron than in the basins. Later studies on the palaeogeography of the red ironstone occurrences, which were carried out simultaneously with investigations of the conodont succession, were able to confirm these results and supplement them in greater detail (Krebs 1959a, 1959b, 1960; Krebs \& Rabien 1964). 
Summaries of the geological conditions of the Roteisenstein of Dillenburg, its history of formation as well as its history of research were published in the explanations of the geological map sheets of Dillenburg and Oberscheld (Lippert \& Hentschel in Lippert et al. 1970; Lippert \& Nesbor in Bender et al. 1997).

\section{Ammonoid stratigraphy}

All the material studied herein is part of historical collections; therefore, little is known about the precise stratigraphic position of the various species. In some cases, assemblages from specific localities exist, but even these cannot be assumed with certainty to be from the same stratum. In several cases this is even excluded, for example when genera from both the Givetian (e.g., Pharciceras Hyatt, 1884) and the Frasnian (e.g., Manticoceras Hyatt, 1884) are named from the same locality (e.g., Königszug Mine). Even if the locality information is more precise (e.g., Königszug Mine, $60 \mathrm{~m}$ level), stratigraphically distinctly different genera (e.g., Pharciceras and Manticoceras) may have been collected together. Therefore, no precise stratigraphic classification is possible on the basis of the available material.

In their review of the Devonian ammonoid zones, Becker \& House (2000) divided the late Givetian into five ammonoid "standard" zones, which should be recognisable in both the Rhenish Slate Mountains and the Anti-Atlas. These are, in ascending order, (1) Pharciceras amplexum Zone (in Morocco and Germany replaced by Pharciceras tridens (Sandberger \& Sandberger, 1850) as index species); note that this zone was in the same article called Pharciceras lateseptatum Zone (Becker \& House 2000: table 1), (2) Stenopharciceras lateseptatum Zone (in Morocco and Germany defined by Stenopharciceras lunulicosta (Sandberger \& Sandberger, 1850) and Mzerrebites erraticus (Petter, 1959) as index species), (3) Synpharciceras clavilobum Zone, (4) Pseudoprobeloceras pernai Zone (in Morocco additionally with Taouzites taouzensis (Termier \& Termier, 1950) as index species) and (5) the Petteroceras errans Zone, which should be represented by the Ponticeras kayseri Wedekind, 1918 Zone in Germany.

However, this succession of ammonoid zones could not be demonstrated in any section; the zonation is rather based on the expectation that the progressive evolution towards more complex suture lines in pharciceratids is also reflected in the stratigraphic succession of species and genera. The study of the species-rich assemblages in the Anti-Atlas of Morocco (Bockwinkel et al. 2009, 2013a, 2015, 2017) has shown that at least in these, there is a co-occurrence of the genera Pharciceras, Synpharciceras Schindewolf, 1940, Pseudoprobeloceras Bensaïd, 1974, Taouzites Korn, 2001, and sometimes also with Petteroceras Bogoslovsky in Bogoslovsky et al., 1962. All these occurrences would therefore be placed in either the Pseudoprobeloceras pernai Zone or the Petteroceras errans Zone.

A similar biostratigraphic attribution might be true for the occurrences of Pharciceras and related genera in the Red Ironstone of Dillenburg. There is no evidence that the forms originate from widely separate horizons; on the contrary, the collections rather indicate a short interval in which most of the species described here lived together. However, only one rock can be used to support this hypothesis, which provided specimens of the species Pharciceras kayseri and Stenopharciceras lotzi $\mathrm{sp}$. nov. The frequent occurrence of Pseudoprobeloceras pernai (Wedekind, 1918) in the Red Ironstone would speak for a most likely attribution to the Pseudoprobeloceras pernai Zone.

In summary, based on the available data, the species described here originate from three main stratigraphic intervals (Fig. 1), (1) Maenioceras terebratum Zone (Maenioceras), (2) Pseudoprobeloceras pernai Zone (Pharciceras, Evopharciceras gen. nov., Extropharciceras Bockwinkel, Becker \& Ebbighausen, 2009, Stenopharciceras Montesinos \& Henn, 1986, Synpharciceras, Pluripharciceras Bockwinkel, Becker \& Ebbighausen, 2013), Lunupharciceras Korn in Korn \& Klug, 2002 and (3) Sandbergeroceras costatum Zone (Sandbergeroceras Hyatt, 1884). 


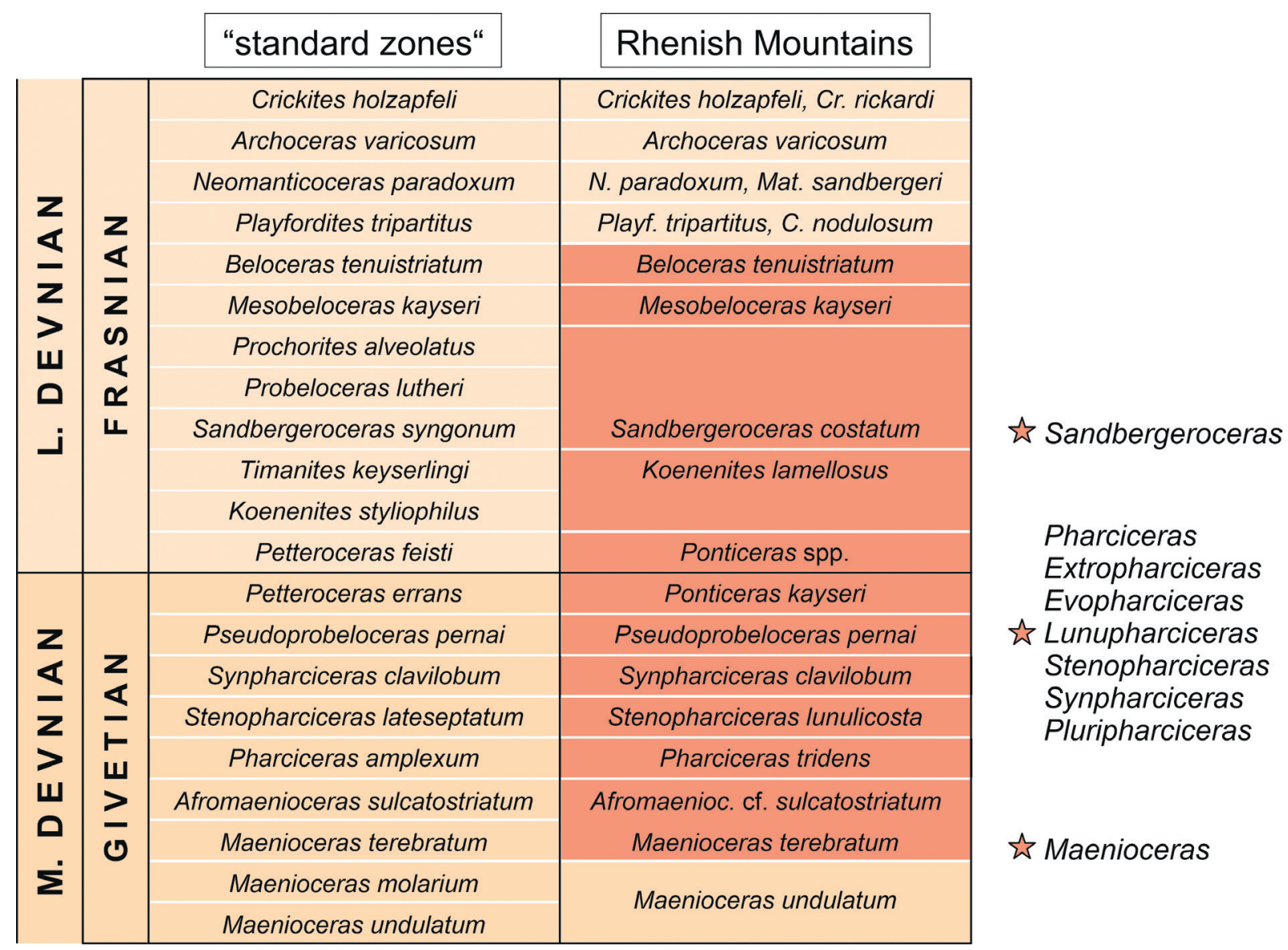

Fig. 1. Givetian and Frasnian ammonoid stratigraphy (after Becker \& House 2000), probable extent of the Red Ironstone of Dillenburg and probable position of the ammonoid assemblages described here.

\section{Material and methods}

There was a total of about 165 specimens available for our study, most from the area of Dillenburg and some from Wetzlar at the eastern margin of the Rhenish Mountains (Fig. 2). The specimens are preserved in iron-rich micritic or sparitic limestone or in haematitic ironstone, some of them in a pure haematite ore. Most specimens are tectonically deformed laterally, but often the shell ornamentation is well preserved. Inner whorls and septa are often destroyed and replaced by coarse calcite, so that the important features of conch ontogeny and suture line are sometimes destroyed.

The material from the Red Ironstone Formation comes from four principal stratigraphic intervals, in ascending order:

- middle Givetian (assemblage with Maenioceras Schindewolf, 1933)

- late Givetian (assemblage with Pharciceras, Pseudoprobeloceras)

- early Frasnian (assemblage with Koenenites Wedekind, 1913, Acanthoclymenia Hyatt, 1900)

- middle Frasnian (assemblage with Manticoceras, Mesobeloceras Glenister, 1958)

Almost all the material consists of isolated specimens without assignment to any stratigraphic scheme. Information on the co-occurrence of taxa could only rarely be obtained from the context of the collections.

Most of the material kept in the fossil cephalopod collection of the Museum für Naturkunde, Berlin, was collected in a period between 1830 and 1930: Beyrich collected some material in the course of 
research for his dissertation (Beyrich 1837b) and also used material collected by Erbreich and Kauth, as documented on the labels. Probably from the 1830 s to 1870 s, the private collectors Dannenberg, Koch and Krüger gathered material and donated it to the "Geologisches Landesmuseum Berlin" (today Museum für Naturkunde). The Dannenberg collection was already used for the monograph of Sandberger \& Sandberger (1850-1856) and contains several type specimens.

Much more material was added by mapping activities of geologists of the Prussian Geological Survey: Lotz and others (probably miners) assembled a large collection around 1900, Ahlburg around 1910 and Kegel in the late 1920s in the course of a survey for a revision of the geological maps.

We studied the following species (with the number of specimens from the Red Ironstone):

Maenioceras terebratum (Sandberger \& Sandberger, 1851) - 6 specimens

Maenioceras ornatum sp. nov. -15 specimens

Pharciceras beyrichi sp. nov. -2 specimens

Pharciceras oberscheldense Bockwinkel \& Korn in Bockwinkel et al. (2013) - 14 specimens

Pharciceras tridens (Sandberger \& Sandberger, 1850) - 7 specimens

Pharciceras kayseri Wedekind, $1918-7$ specimens

Pharciceras kruegeri sp. nov. -7 specimens

Pharciceras ferrum sp. nov. -10 specimens

Pharciceras galeatum Wedekind, 1918 - 3 specimens

Evopharciceras formosum gen. et sp. nov. -2 specimens

Extropharciceras metallicum sp. nov. -12 specimens

Extropharciceras becheri (von Buch, 1832) - 1 specimen

Lunupharciceras lunulicosta (Sandberger \& Sandberger, 1850) - 37 specimens

Lunupharciceras kochi sp. nov. - 12 specimens

Stenopharciceras lotzi sp. nov. -6 specimens

Synpharciceras clavilobum (Sandberger \& Sandberger, 1850) - 7 specimens

Pluripharciceras ahlburgi sp. nov. -22 specimens

Sandbergeroceras tuberculosocostatum (Sandberger \& Sandberger, 1850) - 2 specimens

Sandbergeroceras costatum (d'Archiac \& de Verneuil, 1842) - 1 specimen

Sandbergeroceras archiaci $\mathrm{sp}$. nov. - 1 specimen
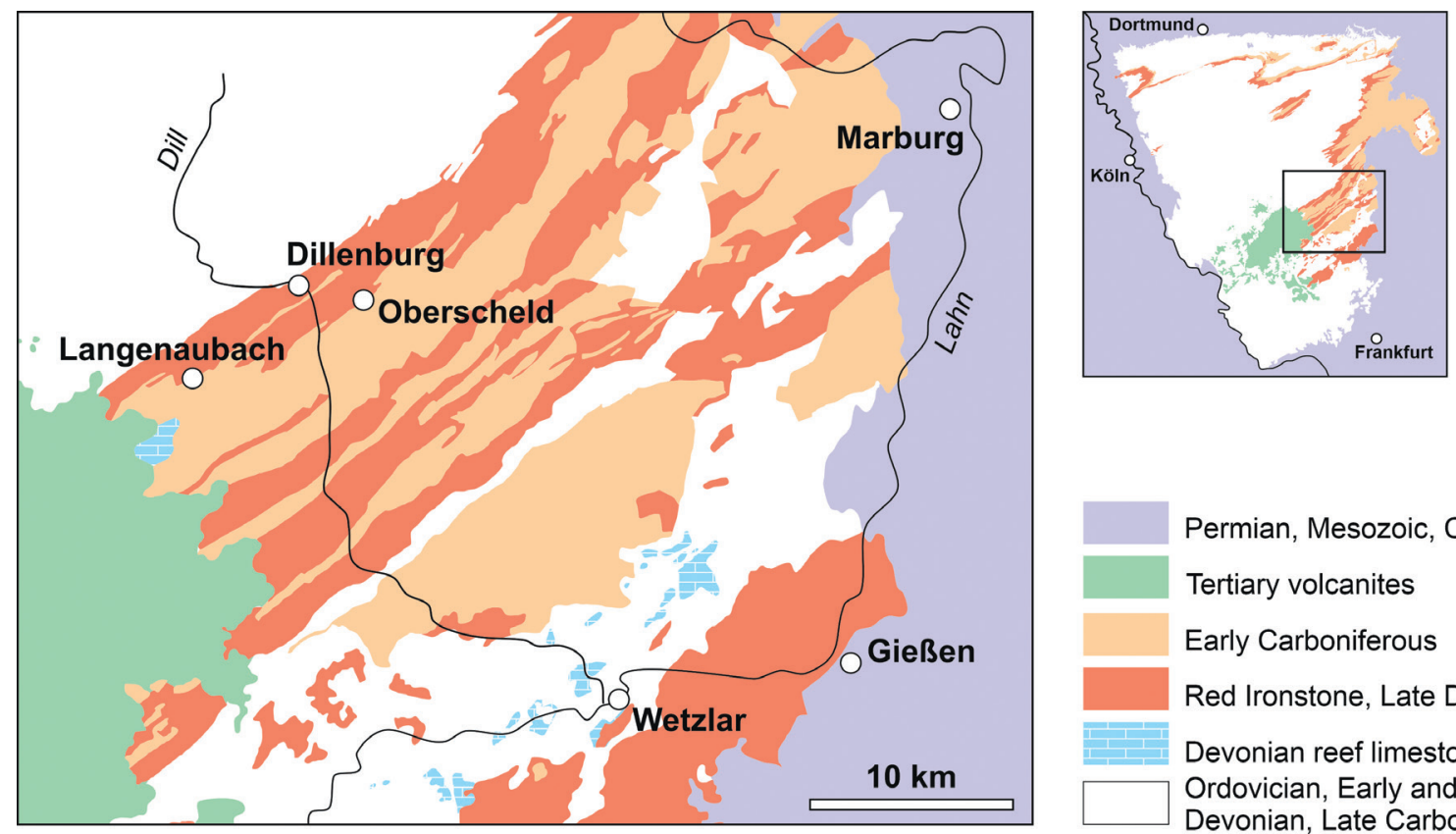

Fig. 2. The geographic position of the fossil localities in the Rhenish Mountains. 
The description of the material follows, as far as possible, the scheme for Palaeozoic ammonoids outlined by Korn (2010) and Klug et al. (2015) (Fig. 3). However, due to the limitation of ontogenetic data, the descriptions must remain incomplete. The embedding of most of the material in very hard ironstone precluded the complete preparation of most of the specimens. In addition, many of the specimens are tectonically distorted, so that photographing dorsal and ventral views was difficult. In the following, we therefore present reconstructed dorsal projections to give a better picture of the conch geometry.

\section{Abbreviations}
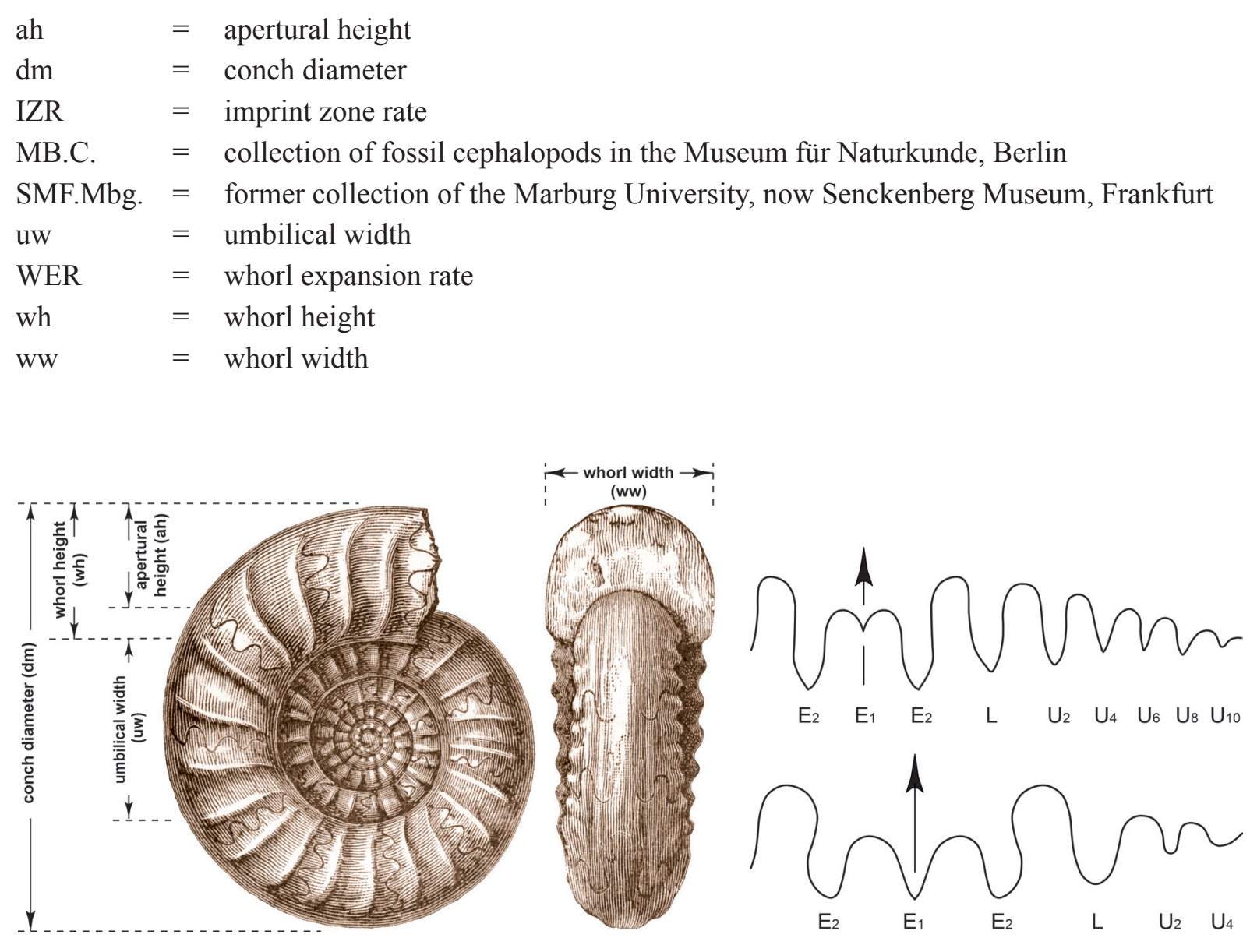

Fig. 3. The morphological terms used in the descriptions of the ammonoid conchs and suture lines. Illustration from Foord \& Crick (1897), after d'Archiac \& de Verneuil (1842).

\section{Results}

Order Agoniatitida Ruzhencev, 1957

Suborder Pharciceratina Korn, 1998

Superfamiliy Pharciceratoidea Hyatt, 1900

Family Maenioceratidae Bogoslovsky, 1958

For a definition of the family and the included genera, see Korn \& Klug (2002: 139). 


\section{Type species}

Genus Maenioceras Schindewolf, 1933

Goniatites terebratus Sandberger \& Sandberger, 1851, by original designation.

\section{Diagnosis}

Maenioceratidae with strong ventrolateral grooves; shell without constrictions or internal thickenings. Suture line formula (E2 E1 E2) L U2 U1 I. Lateral lobe V-shaped, moderately deep; ventrolateral saddle subacute.

\section{Included species}

Goniatites terebratus Sandberger \& Sandberger, 1851, Rhenish Mountains; Maeneceras decheni Holzapfel, 1895, Rhenish Mountains; Maenioceras heinorum Ebbighausen, Becker \& Bockwinkel in Ebbighausen et al., 2007, Rhenish Mountains; Maeneceras tenue Holzapfel, 1895, Rhenish Mountains; Maenioceras ornatum sp. nov., Rhenish Mountains.

\section{Remarks}

The genus Maenioceras needs revision, especially with regard to the North African records. Only then can it be determined how many and which species can be considered valid. The current knowledge about the possible concordance of Central European and North African species is poor and little is known about the diversity of the maenioceratids. A revision of the genus is not the subject of the investigations here. We limit ourselves to the description of the specimens found in the Red Ironstone.

Maenioceras terebratum (Sandberger \& Sandberger, 1851)

Figs 4-5; Table 1

Goniatites terebratus Sandberger \& Sandberger, 1851: 99, pl. 5 fig. 3a, c.

Maenioceras terebratum - Walliser 1970: 121, pl. 2 figs 1-2, text-fig. 5d. - House 1971: 28, pl. 2 fig. 5. — Walliser et al. 1995: 111, text-fig. 6d. — Korn \& Klug 2002: text-figs 132, 133a, e-g.

? Maenioceras terebratum - Termier \& Termier 1950: pl. 143 fig. 28 (non figs 25-27=Afromaenioceras sulcatostriatum (Bensaïd, 1974)). - Petter 1959: 122, pl. 6 figs 10, 18, 22?, text-figs 16, 31a (non fig. $17=$ Afromaenioceras sulcatostriatum). - Belka et al. 1999: pl. 4 figs 7-8. - Aboussalam \& Becker 2001: 89, pl. 1 figs 10-11. — Becker et al. 2004: 42, pl. 1 figs 17-18.

? Maenioceras terebratum terebratum - Bensaïd 1974: 103, pl. 1 figs 11-12, pl. 2 fig. 1, pl. 3 fig. 5, pl. 6 figs 2-3, text-fig. 12b. - Wissner \& Norris 1991: 66, pl. 3.1 figs 6-8, pl. 3.2 figs 1-5, 13, 14, text-fig. 3.16.

? Maenioceras terebratum tenue - Bensaïd 1974: 104, text-fig. 10a. — Wissner \& Norris 1991: 67, pl. 3.1 figs 9-11, text-fig. 3.14-3.17.

non Maeneceras terebratum - Holzapfel 1895: 107, pl. 4 figs 14, 18, pl. 6 figs 6-7, 9 (only). — Foord \& Crick 1897: 123, text-fig. 57. — Frech 1897: pl. 32a fig. 17a-b; 1902: 54, text-fig. 15. — Wedekind 1918: 114, pl. 16 fig. 7, text-fig. 23a.

\section{Diagnosis}

Maenioceras with extremely discoidal, involute conch at $40 \mathrm{~mm} \mathrm{dm}$ (ww/ $\mathrm{dm} \sim 0.25$; uw/ $\mathrm{dm} \sim 0.05$ ); whorl profile strongly compressed $(\mathrm{ww} / \mathrm{wh}=0.50)$. Flanks flattened and nearly parallel with subumbilical depression, venter narrowly rounded. Growth lines fine, strongly biconvex; ventrolateral shoulder with a 
distinct spiral groove. Suture line with very wide external lobe with acute ventrolateral saddle and a low median saddle, and a V-shaped lateral lobe and two U-lobes.

\section{Material examined}

\section{Lectotype}

GERMANY • Rhenish Mountains, Villmar; middle Givetian ("Stringocephalenkalk"); 33c (Wiesbaden Museum); figured by Sandberger \& Sandberger (1850-1856: pl. 5 fig. 3a), re-illustrated here in Fig. 4A; Wiesbaden Museum nr. 33c.

\section{Paratypes}

GERMANY - 2 specimens; Rhenish Mountains, Villmar; middle Givetian ("Stringocephalenkalk"); 33a-b (Wiesbaden Museum), illustrated here in Fig. 4C-D; Wiesbaden Museum nr. 33a-b.

\section{Additional material}

GERMANY - 4 specimens; Rhenish Mountains, Wetzlar (Philippswonne Mine); middle Givetian (Red Ironstone); von Buch Coll.; MB.C.4976, MB.C.4977.1 to MB.C.4977.3 • 2 specimens; Rhenish
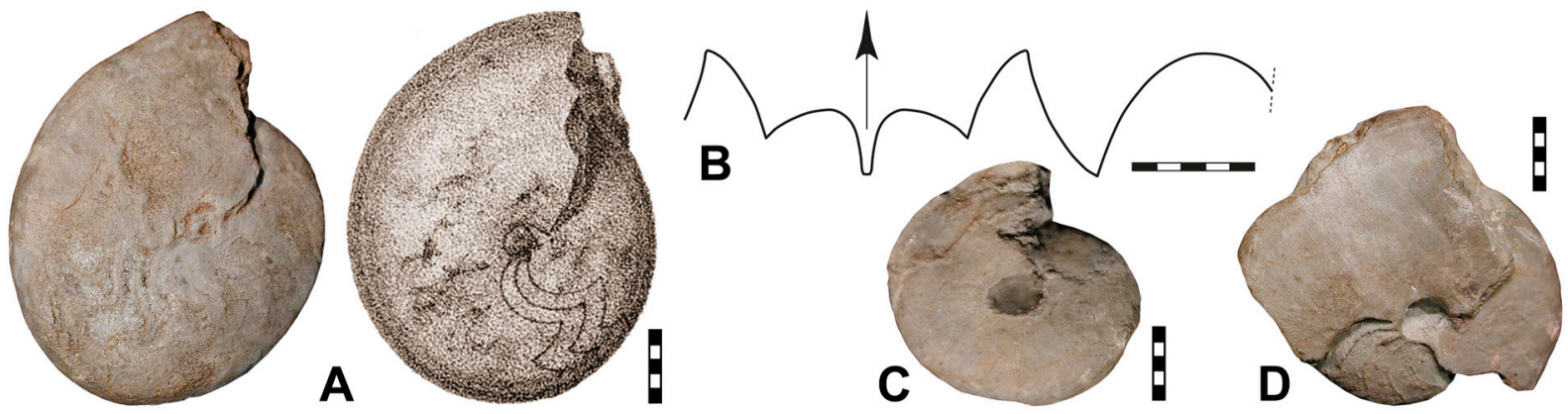

Fig. 4. Maenioceras terebratum (Sandberger \& Sandberger, 1851), specimens from Villmar in the Wiesbaden Museum. A. Lectotype 33c, photograph and reproduction of the figure in Sandberger \& Sandberger (1850-1856: pl. 5 fig. 3a). B. Suture line of the lectotype, after Sandberger \& Sandberger (1850-1856: pl. 5 fig. 3c). C. Specimen 33a. D. Specimen 33b. Scale bar units $=1 \mathrm{~mm}$.
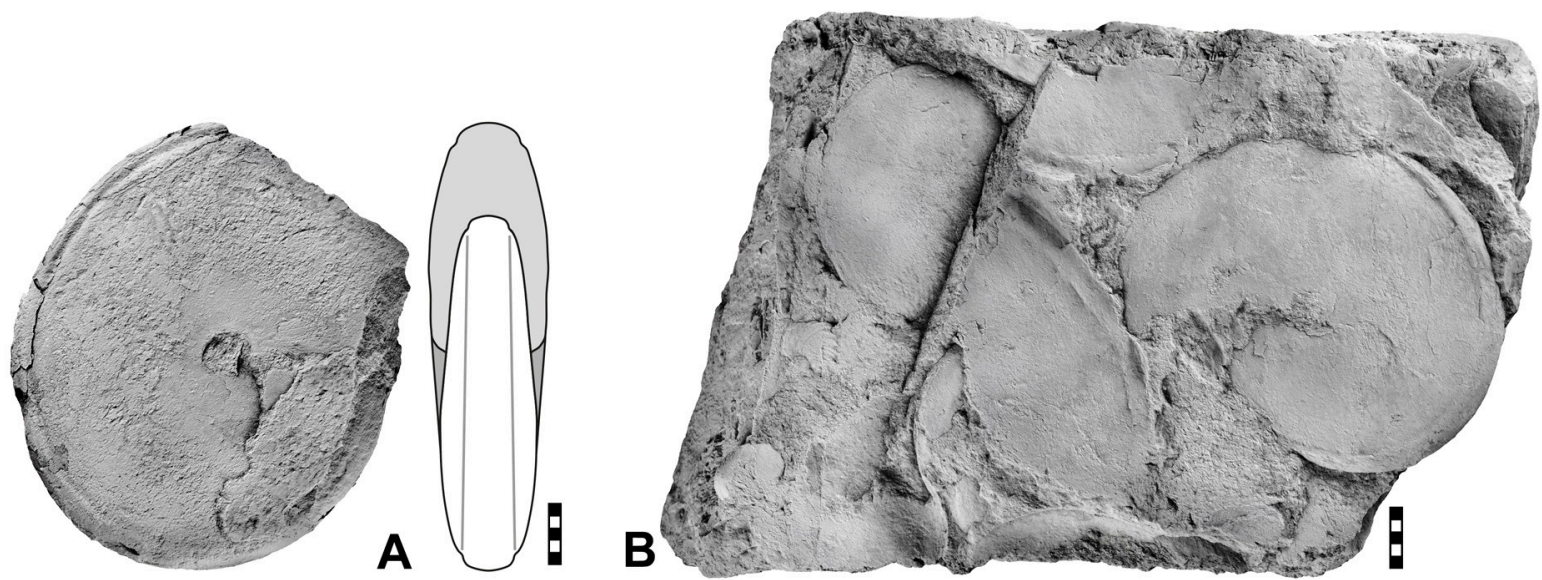

Fig. 5. Maenioceras terebratum (Sandberger \& Sandberger, 1851) from the Philippswonne Mine near Wetzlar. A. Specimen MB.C.4977.1 (von Buch Coll.). B. Specimen MB.C.4976 (von Buch Coll.). Scale bar units $=1 \mathrm{~mm}$. 
Table 1. Conch dimensions and ratios of selected specimen of Maenioceras terebratum (Sandberger \& Sandberger, 1851).

\begin{tabular}{ccccccccccc}
\hline Specimen & dm & ww & wh & uw & ah & ww/dm & ww/wh & uw/dm & WER & IZR \\
\hline MB.C.4977.1 & 44.5 & 10.6 & 21.8 & 2.5 & 10.6 & 0.24 & 0.48 & 0.06 & 1.72 & 0.51 \\
\hline
\end{tabular}

Mountains, Wetzlar (Philippswonne Mine); middle Givetian (Red Ironstone); MB.C.30228.1, MB.C.30228.2.

\section{Description}

The material from Wetzlar contributes little to the knowledge of the species. Specimen MB.C.4977.1 is a weakly deformed, comparatively well-preserved specimen with $45 \mathrm{~mm}$ conch diameter in haematitic ironstone and the best available specimen that allows the study of the adult conch (Fig. 5A). It is, at nearly $45 \mathrm{~mm}$ diameter, extremely discoidal with a very narrow umbilicus ( $\mathrm{ww} / \mathrm{dm}=0.24 ; \mathrm{uw} / \mathrm{dm}=0.06)$. The whorl profile shows that the conch is widest in the midflank area; the flanks stand parallel and are weakly convex. They converge towards the umbilicus to form a shallow groove, from which the umbilical margin is elevated like a low rim. The flanks also converge towards the narrowly rounded venter, which is separated from the flanks by a rather deep ventrolateral groove. The shell ornament is visible in a small area near the aperture and shows very weak growth lines.

MB.C.4976 is a rather poorly preserved specimen of $42 \mathrm{~mm}$ diameter, embedded in an ironstone slab (Fig. 5B). It shows the same conch proportions as specimen MB.C.4977.1.

\section{Remarks}

The type material from the Stringocephalus Limestone of Villmar is poorly preserved. It hardly allows an accurate description of the conch shape and the ornament. In addition, there is the rather small size of the lectotype which is $25 \mathrm{~mm}$ in diameter. The identification of the specimens from the Roteisenstein is therefore mainly based on the compressed conch shape of the type material.

It is not certain whether the findings reported from North Africa and Canada actually belong to M. terebratum. Göddertz (1987) described sickle-shaped furrows on the inner half of the flank of larger specimens from Algeria; apparently this feature does not appear in the specimens from the Rhenish Mountains. However, it is not clear whether the furrows are actually shell constrictions or internal shell thickenings.

Maenioceras terebratum differs from M. ornatum sp. nov. in the slenderer conch, the much narrower and rounded venter and the much weaker ornament with finer growth lines. Already Holzapfel (1895) discussed the morphological differences of specimens attributed by him to "Maeneceras terebratum" between the various occurences. However, he considered the difference in the weaker ornament of specimens from the Stringocephalus Limestone compared to the occurrence in the cephalopod limestone as caused by preservation. This is obviously not the case, as the specimens from the Red Ironstone of Wetzlar share the weak ornament with the specimens from the Stringocephalus Limestone of Villmar, but differ from the Red Ironstone specimens from Oberscheld.

Maenioceras ornatum sp. nov. urn:1sid:zoobank.org:act:D40EFEA4-C79A-4A01-A3AD-4DDB2AF923C5

Figs 6-7; Table 2

Maeneceras terebratum - Holzapfel 1895: 107, pl. 4 figs 14, 18, pl. 6 figs 6-7, 9 (only). — Foord \& Crick 1897: 123, text-fig. 57. — Frech 1897: pl. 32a fig. 17a-b; 1902: 54, text-fig. 15. — Wedekind 1918: 114, pl. 16 fig. 7, text-fig. 23a. 
Maenioceras terebratum - Walliser 1970: 121, pl. 2 figs 1-2, text-fig. 5d. - House 1971: 28, pl. 2 fig. 5. — Walliser et al. 1995: 111, text-fig. 6d. — Korn \& Klug 2002: text-figs 132, 133a.

\section{Diagnosis}

Maenioceras with thinly discoidal, involute conch at $25 \mathrm{~mm} \mathrm{dm} \mathrm{(ww/dm} \sim 0.45 ; \mathrm{uw} / \mathrm{dm} \sim 0.05$ ). Whorl profile slightly compressed (ww/wh $\sim 0.90$ ); flanks flattened and nearly parallel, venter broadly rounded. Growth lines coarse, lamellar, strongly biconvex; ventrolateral shoulder with a distinct spiral groove.

\section{Etymology}

Named after the Latin 'ornatum', meaning 'decorated', because of the shell ornament.

\section{Material examined}

\section{Holotype}

GERMANY - Rhenish Mountains, Oberscheld (possibly Caroline Mine); middle Givetian (Red Ironstone); MB.C.30229.1. (Fig. 6C)

\section{Paratypes}

GERMANY • 13 specimens; Rhenish Mountains, Oberscheld (possibly Caroline Mine); middle Givetian (Red Ironstone); MB.C.30229.2 to MB.C.30229.14 • 1 specimen; Rhenish Mountains, Oberscheld (Caroline Mine, 128 m level); middle Givetian (Red Ironstone); Möbus Coll.; MB.C.30230.
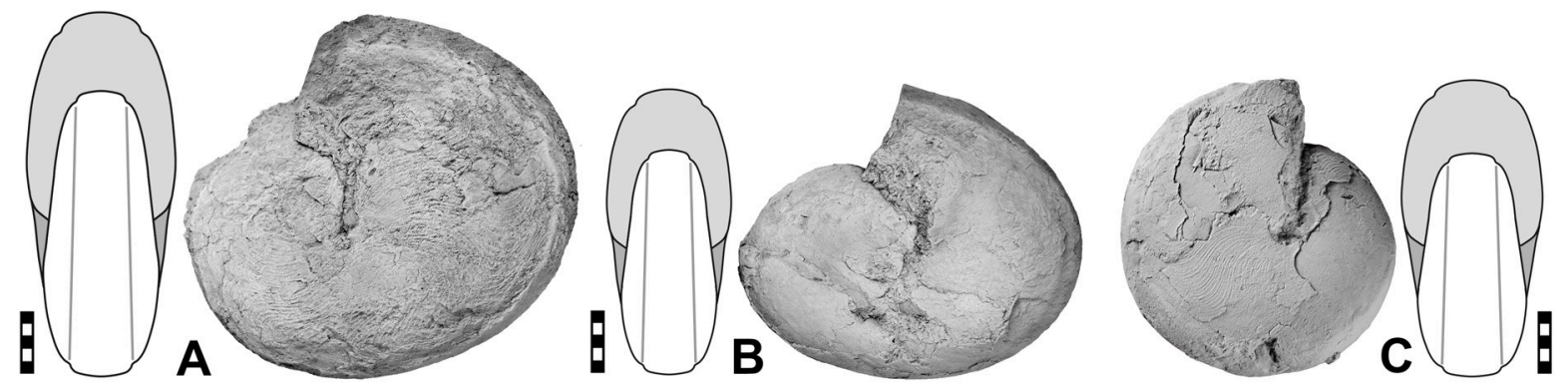

Fig. 6. Maenioceras ornatum sp. nov., all probably from the Caroline Mine near Oberscheld. A. Paratype MB.C.30229.2. B. Paratype MB.C.30229.3. C. Holotype MB.C.30229.1. Scale bar units $=1 \mathrm{~mm}$.
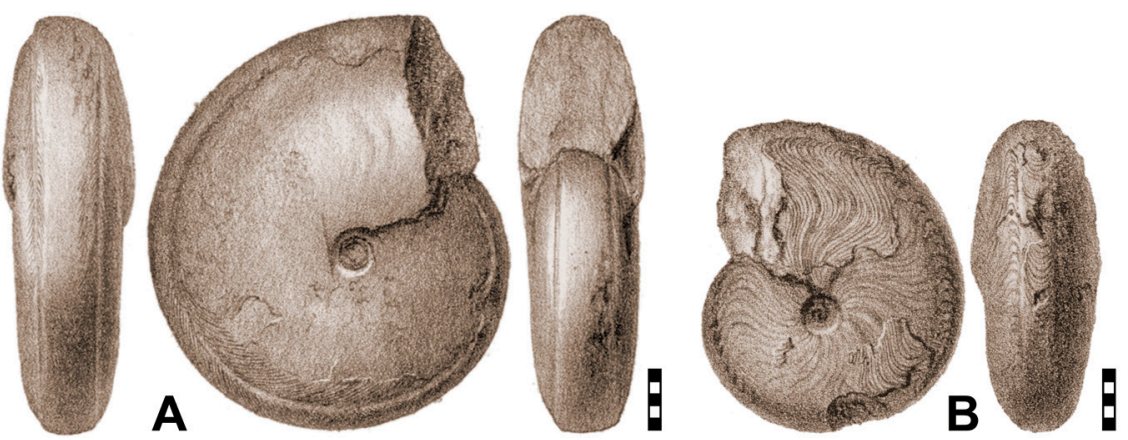

Fig. 7. Maenioceras ornatum sp. nov. A. Reproduction of the figure in Holzapfel (1895: pl. 6 fig. 9) of a specimen from Martenberg near Adorf. B. Reproduction of the figure in Holzapfel (1895: pl. 4 fig. 14) of a specimen from Ense near Bad Wildungen. Scale bar units $=1 \mathrm{~mm}$. 
Table 2. Conch dimensions and ratios of selected specimens of Maenioceras ornatum sp. nov.

\begin{tabular}{ccccccccccc}
\hline Specimen & dm & ww & wh & uw & ah & ww/dm & ww/wh & uw/dm & WER & IZR \\
\hline MB.C.30229.2 & 32.9 & 13.0 & 16.4 & 1.8 & - & 0.40 & 0.79 & 0.05 & - & - \\
MB.C.30229.3 & 24.9 & 11.0 & 12.5 & 1.3 & - & 0.44 & 0.88 & 0.05 & - & - \\
MB.C.30229.1 & 23.1 & 10.2 & 11.4 & 1.6 & 5.4 & 0.44 & 0.89 & 0.07 & 1.70 & 0.53 \\
\hline
\end{tabular}

\section{Description}

The description is based on three specimens:

Holotype MB.C.30229.1: weakly deformed, comparatively well-preserved specimen with $23 \mathrm{~mm}$ conch diameter in red ironstone (Fig. 6C).

Paratype MB.C.30229.2: laterally deformed, incomplete, rather poorly preserved specimen with about $35 \mathrm{~mm}$ conch diameter in red ironstone (Fig. 6A).

Paratype MB.C.30229.3: laterally deformed, rather poorly preserved specimen with about $25 \mathrm{~mm}$ conch diameter in red ironstone (Fig. 6B).

The three type specimens listed above allow the study of conch geometry and ornament between 20 and $35 \mathrm{~mm}$ conch diameter. They show thinly discoidal conchs with parallel flanks; the whorl profile is widest near the midflank, from where the flanks slowly converge towards the umbilicus and a little faster towards the venter. Flanks and venter are separated by a narrowly rounded shoulder that is accompanied, on the flank side, by a shallow longitudinal groove.

Particularly in the holotype MB.C.30229.1, the ornament is well-preserved and shows lamellar growth lines with a broadly rounded dorsolateral projection, a slightly narrower lateral sinus, a very high and narrow ventrolateral projection and a very deep, narrow ventral sinus. Remains of the wrinkle-layer are preserved in the dorsal whorl area; they show very delicate lines.

\section{Remarks}

The new species was previously described by Holzapfel (1895) from well-preserved material from the Roteisenstein from Adorf (Fig. 7A). The large specimen illustrated by Holzapfel agrees very well with the specimens from Oberscheld in terms of conch form and ornament. Holzapfel already recognized the differences between the specimens from the Stringocephalus Limestone of Villmar (M. terebratum) and from the Roteisenstein of Oberscheld (M. ornatum sp. nov.) in the strength of the growth lines. However, he considered both forms to belong to M. terebratum.

The new species differs from Maenioceras terebratum in the stouter conch (ww/ $\mathrm{dm}=0.40-0.45$ in M. ornatum sp. nov. at $30 \mathrm{~mm}$ conch diameter but $0.25-0.30$ in M. terebratum), the wider and slightly flattened venter and the much coarser ornament with lamellar growth lines.

Family Pharciceratidae Hyatt, 1900

For the systematics and taxon content of this family, see Korn \& Klug (2002). Note that Bockwinkel et al. $(2009,2013 a, 2015,2017)$ added several genera to the family. 


\section{Subfamilies included}

Pharciceratinae Hyatt, 1900; Synpharciceratinae Schindewolf, 1940.

Subfamily Pharciceratinae Hyatt, 1900

\section{Diagnosis}

Pharciceratidae with open umbilicus in all growth stages; umbilical width ratio decreasing in the adult stage. Suture line with four to six umbilical lobes.

\section{Included genera}

Pharciceras Hyatt, 1884; Allopharciceras Bockwinkel, Becker \& Aboussalam, 2017; Extropharciceras Bockwinkel, Becker \& Ebbighausen, 2009; Lunupharciceras Korn in Korn \& Klug, 2002; Oxypharciceras Bockwinkel, Becker \& Aboussalam, 2017; Sphaeropharciceras Bogoslovsky, 1955 (probably synonym of Pharciceras); Transpharciceras Bockwinkel, Becker \& Ebbighausen, 2013; Evopharciceras gen. nov.

\section{Remarks}

Bogoslovsky (1955) introduced the genus Sphaeropharciceras; the species S. sandbergerorum, which was newly named by him at the same time, was determined as the type species. This species was based on an illustration by Sandberger \& Sandberger (1850-1856: pl. 9 fig. 2), in which a small (13 mm conch diameter), almost globular specimen is shown.

The specimen was then figured and briefly discussed by House (in House \& Ziegler 1977: pl. 5 figs 24-26). House concluded that the distorted specimen has to be included in Pharciceras tridens. Unfortunately, this specimen is now considered lost; therefore, it cannot be verified whether it is indeed to be considered a synonym of $P$. tridens. Owing to the small size, however, it should hardly be possible to formulate a satisfactory species diagnosis.

Genus Pharciceras Hyatt, 1884

\section{Type species}

Goniatites tridens Sandberger \& Sandberger, 1850, subsequently designated by Holzapfel (1889).

\section{Diagnosis}

Pharciceratidae with subevolute to evolute juvenile stage, whorl profile strongly to extremely depressed. Adult stage with weakly depressed to weakly compressed whorl profile; venter rounded or tabulate. Juvenile stage sometimes finely ribbed, adult stage with weak to strong, single or paired ventrolateral grooves. Suture line with very wide external lobe, deep or shortened median $\mathrm{E}_{1}$ lobe, low median saddle, short $\mathrm{E}_{2}$ lobe, large, midflank lateral lobe, two outer and two inner umbilical lobes. Suture line formula $\left(\mathrm{E}_{2} \mathrm{E}_{1} \mathrm{E}_{2}\right) \mathrm{L} \mathrm{U}_{2} \mathrm{U}_{4}: \mathrm{U}_{3} \mathrm{U}_{1} \mathrm{I}$.

\section{Included species}

Goniatites tridens Sandberger \& Sandberger, 1850, Rhenish Mountains; Goniatites amplexus Hall, 1886, New York State; Pharciceras applanatum Bensaïd, 1974, Anti-Atlas; Pharciceras barnetti Work, Mason \& Klapper, 2007, Kentucky; Pharciceras bidentatum Petter, 1959, Anti-Atlas; Pharciceras concurrens Bockwinkel, Becker \& Aboussalam, 2017, Anti-Atlas; Pharciceras darkaouense Bockwinkel, Becker \& Ebbighausen, 2009, Anti-Atlas; Pharciceras decoratum Bockwinkel, Becker \& 
Ebbighausen, 2013, Anti-Atlas; Pharciceras elevatum Bockwinkel, Becker \& Aboussalam, 2017, AntiAtlas; Pharciceras fornix Bockwinkel, Becker \& Ebbighausen, 2013, Anti-Atlas; Pharciceras galeatum Wedekind, 1918, Rhenish Mountains; Pharciceras kayseri Wedekind, 1918, Rhenish Mountains; Pharciceras involutum Bockwinkel, Becker \& Ebbighausen, 2013, Anti-Atlas; Prolecanites lateseptatus Frech, 1902, Montagne Noire; Pharciceras oberscheldense Bockwinkel \& Korn in Bockwinkel et al., 2013, Rhenish Mountains; Pharciceras pargai Montesinos \& Henn, 1986, Cantabrian Mountains; Sphaeropharciceras sandbergerorum Bogoslovsky, 1955, Rhenish Mountains; Pharciceras subconstans Bockwinkel, Becker \& Ebbighausen, 2013, Anti-Atlas; Pharciceras beyrichi sp. nov., Rhenish Mountains; Pharciceras ferrum sp. nov., Rhenish Mountains; Pharciceras kruegeri sp. nov., Rhenish Mountains.

\title{
Remarks
}

The morphological range of the genus Pharciceras has been continuously reduced in the course of time. While Hyatt (1883-1884) placed the two morphologically quite distant species $P$. tridens and P. clavilobum in Pharciceras, more and more genera were added. This was done largely on the basis of the different number of elements of the suture line.

Of all genera within the family Pharciceratidae, Pharciceras has the lowest number of lobes (subdivided external lobe, lateral lobe, four umbilical lobes and internal lobe). The genus Extropharciceras, similar in conch form and ornament, differs from Pharciceras in the formation of additional sutural elements and has five or six umbilical lobes.

\author{
Pharciceras beyrichi sp. nov. \\ urn:1sid:zoobank.org:act:6E860B7E-D08C-4491-9649-B94A153C0191
}

Figs 8-9; Table 3

\section{Diagnosis}

Species of Pharciceras with thickly discoidal, subevolute conch at $35 \mathrm{~mm} \mathrm{dm} \mathrm{(ww/dm} \sim 0.55 ; \mathrm{uw} / \mathrm{dm}$ $\sim 0.38$ ). Whorl profile depressed, crescent-shaped at $35 \mathrm{~mm} \mathrm{dm} \mathrm{(ww/wh} \sim 1.75)$; whorl expansion rate low (WER $\sim 1.55$ ). Whorl profile with broadly convex flanks continuing to the very broadly rounded venter. Growth lines coarse, strongly biconvex; ventrolateral shoulder with two spiral grooves. Outer suture line with symmetric, V-shaped prongs of the external lobe, a lancolate, blunt lateral lobe and very small rounded $\mathrm{U}_{2}$ and $\mathrm{U}_{4}$ lobes.

\section{Etymology}

Named after Heinrich Ernst Beyrich (1815-1896), one of the pioneers of studying fossils from the Red Ironstone.

\section{Material examined}

\section{Holotype}

GERMANY • Rhenish Mountains, Oberscheld; late Givetian (Red Ironstone); Koch Coll.; MB.C.22174. (Fig. 8)

\section{Paratype}

GERMANY 1 specimen; Rhenish Mountains, probably from Oberscheld; late Givetian (Red Ironstone); MB.C. 30231. 
Table 3. Conch dimensions and ratios of selected specimen of Pharciceras beyrichi sp. nov.

\begin{tabular}{ccccccccccc}
\hline Specimen & $\mathbf{d m}$ & ww & wh & uw & ah & ww/dm & ww/wh & uw/dm & WER & IZR \\
\hline MB.C.22174 & 34.7 & 18.7 & 10.8 & 13.2 & 6.8 & 0.54 & 1.73 & 0.38 & 1.55 & 0.37 \\
\hline
\end{tabular}

\section{Description}

Holotype MB.C.22174 is laterally slightly deformed, completely chambered specimen with $34 \mathrm{~mm}$ conch diameter in haematitic limestone; small parts of the specimen are covered with shell, the phragmocone is filled with sparry calcite (Fig. 8). The specimen has a thickly discoidal and subevolute conch shape with a low coiling rate at $34 \mathrm{~mm}$ diameter; the whorl profile is depressed with steep umbilical wall and broadly rounded flanks and venter. Two faint ventrolateral spiral grooves on each side separate the flanks from the venter, which is broadly rounded at the largest diameter of the specimen but flattened up to the last volution (Fig. 9B). The ornament shows lamellar growth lines. The suture line has a very wide external lobe with nearly parallel flanks and lanceolate prongs. Two lobes are located on the flank: the asymmetric lateral lobe that is larger than the prongs of the external lobe and the small, rounded $\mathrm{U}_{2}$ lobe (Fig. 9A). A very small $\mathrm{U}_{4}$ lobe is located on the umbilical wall.

\section{Remarks}

The two specimens, of which only the holotype is rather well-preserved, are described here as a new species because a conch morphology cannot be attributed to any other species of Pharciceras. Its conch is stouter (ww/dm $\sim 0.55$ at $35 \mathrm{~mm}$ conch diameter) than in most of the other species of Pharciceras. Juveniles of $P$. kruegeri sp. nov. are also stout, but they possess a narrower umbilicus (uw $/ \mathrm{dm} \sim 0.33$ ) than $P$. beyrichi sp. nov. (uw $/ \mathrm{dm} \sim 0.38$ ) and much weaker ventrolateral grooves.

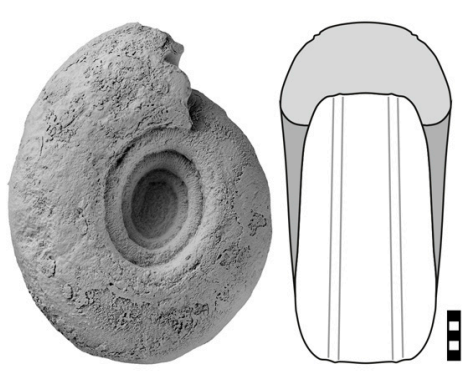

Fig. 8. Pharciceras beyrichi sp. nov., holotype MB.C.22174 (Koch Coll.) from Oberscheld. Scale bar units $=1 \mathrm{~mm}$.
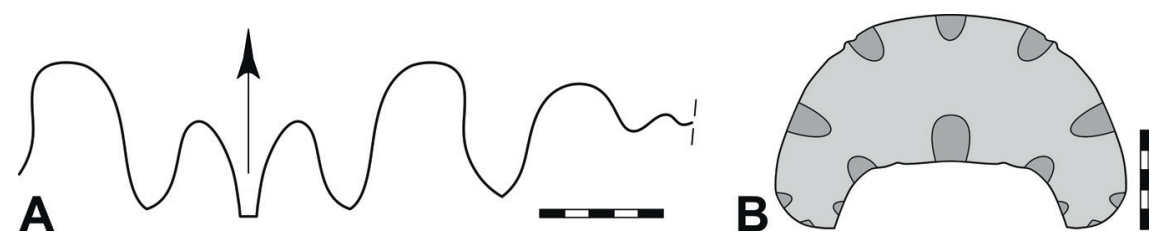

Fig. 9. Pharciceras beyrichi sp. nov. A. Suture line of holotype MB.C.22174 (Koch Coll.) from Oberscheld, at $\mathrm{dm}=26.0 \mathrm{~mm}, \mathrm{ww}=16.5 \mathrm{~mm}, \mathrm{wh}=9.0 \mathrm{~mm}$. B. Surface of the last septum of the holotype. Abbreviations: see Material and methods. Scale bar units $=1 \mathrm{~mm}$. 
Pharciceras tridens is a similar form, but is slenderer with a ww/dm ratio of $\sim 0.45$ at $35 \mathrm{~mm}$ conch diameter. In smaller stages at $25 \mathrm{~mm}$ diameter, the venter is broadly rounded in P. tridens, in contrast to the slightly flattened venter in $P$. beyrichi sp. nov.

Pharciceras oberscheldense Bockwinkel \& Korn in Bockwinkel et al., 2013 Figs 10-13; Tables 4-5

Pharciceras oberscheldense Bockwinkel \& Korn in Bockwinkel et al., 2013b: 262, text-figs 5-8.

Prolecanites tridens - Frech 1888: 29, pl. 2 fig. 5. — Wedekind 1918: 128, text-fig. 37a.

Pharciceras oberscheldense - Bockwinkel \& Korn 2017: 201, text-figs 13-14.

\section{Diagnosis}

Species of Pharciceras with thickly discoidal, subevolute conch at $25 \mathrm{~mm} \mathrm{dm} \mathrm{(ww/dm} \sim 0.50 ; \mathrm{uw} / \mathrm{dm}$ $\sim 0.32$ ) and thinly discoidal, subevolute conch at $60 \mathrm{~mm} \mathrm{dm} \mathrm{(ww/dm} \sim 0.35$; $\mathrm{uw} / \mathrm{dm} \sim 0.30$ ). Whorl profile weakly depressed at $25 \mathrm{~mm} \mathrm{dm}(\mathrm{ww} / \mathrm{wh} \sim 1.35$ ) and weakly compressed at $60 \mathrm{~mm} \mathrm{dm}(\mathrm{ww} / \mathrm{wh}$ $\sim 0.90$ ); whorl expansion rate low to moderate. Venter continuously rounded throughout ontogeny. Adult stage with slightly flattened, converging flanks bordered by a subangular ventrolateral shoulder from the slightly flattened venter. Growth lines coarse, strongly biconvex; ventrolateral shoulder with two spiral grooves. Outer suture line with asymmetric, rounded prongs of the external lobe, a tongue-shaped lateral lobe, a small V-shaped $\mathrm{U}_{2}$ lobe, and a shallow and wide $\mathrm{U}_{4}$ lobe.

\section{Material examined}

\section{Holotype}

GERMANY - Rhenish Mountains, Oberscheld (Grube Sahlgrund); late Givetian (Red Ironstone); Kegel 1929 Coll.; illustrated by Bockwinkel et al. (2013b: text-fig. 5), re-illustrated here in Fig. 10A; MB.C.3620.

\section{Paratypes}

GERMANY • 1 specimen; Rhenish Mountains, Oberscheld; late Givetian (Red Ironstone); Dannenberg Coll.; MB.C.3655 1 specimen; Rhenish Mountains, Oberscheld (Westfeld der Grube Königszug, Firste der 120-150 m Sohle); late Givetian (Red Ironstone); Ahlburg Coll.; MB.C.3662 • 1 specimen; Rhenish Mountains, Oberscheld; late Givetian (Red Ironstone); Krüger 1873 Coll.; MB.C.22161 • 1 specimen; Rhenish Mountains, Oberscheld (Grube Prinzkessel); late Givetian (Red Ironstone); Becker 1902 Coll.; MB.C.22168.

\section{Additional material}

GERMANY • 3 specimens; Rhenish Mountains, Oberscheld (Grube Prinzkessel); late Givetian (Red Ironstone); Welsch 1905 Coll.; SMF.Mbg.6362-6364 • 2 specimens; Rhenish Mountains, Oberscheld (Westfeld der Grube Königszug, Firste der 120-150 m Sohle); late Givetian (Red Ironstone); Ahlburg Coll.; MB.C.3614, MB.C.3622 • 3 specimens; Rhenish Mountains, Oberscheld; late Givetian (Red Ironstone); Lotz 1901-1902 Coll.; MB.C.22156, MB.C.22167, MB.C.30232 • 1 specimen; Rhenish Mountains, Oberscheld (Grube Volpertseiche); late Givetian (Red Ironstone); Bender 1901 Coll.; MB.C.30233 - 1 specimen; Rhenish Mountains, Oberscheld (Grube Königszug, 60 m Sohle); late Givetian (Red Ironstone); Lotz 1902 Coll.; MB.C.30234.

\section{Description}

Eight specimens are selected for description and illustration: 

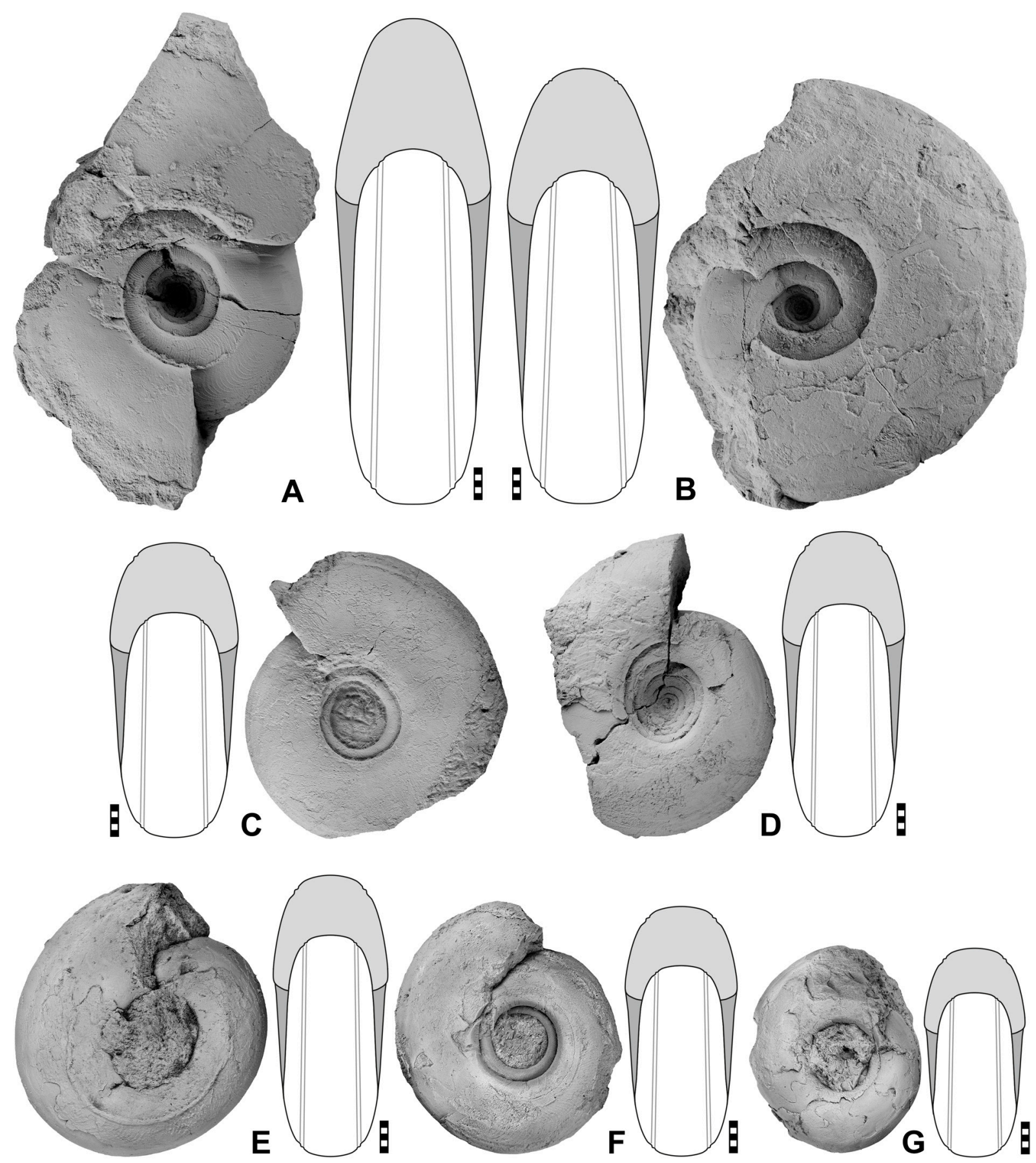

Fig. 10. Pharciceras oberscheldense Bockwinkel \& Korn in Bockwinkel et al., 2013. A. Holotype MB.C.3620 (Kegel 1927 Coll.) from Oberscheld (Sahlgrund Mine). B. Paratype MB.C.22161 (Krüger 1873 Coll.) from Oberscheld. C. Paratype MB.C.22168 (Becker 1902 Coll.) from Oberscheld (Prinzkessel Mine). D. Paratype MB.C.3655 (Dannenberg Coll.) from Oberscheld. E. Specimen SMF.Mbg.6363 (Welsch 1905 Coll.) from Oberscheld (Prinzkessel Mine). F. Specimen SMF.Mbg.6362 from Oberscheld. G. Specimen SMF.Mbg.6364 (Welsch 1905 Coll.) from Oberscheld (Prinzkessel Mine). Scale bar units $=1 \mathrm{~mm}$. 
Holotype MB.C.3620: incomplete specimen with $76 \mathrm{~mm}$ conch diameter in iron-rich sparitic limestone. A segment of the last volution is missing, allowing the study of the penultimate whorl (Fig. 10A).

Paratype MB.C.3655: incomplete specimen with $48 \mathrm{~mm}$ conch diameter in iron-rich limestone; probably the last volution belongs to the body chamber (Fig. 10D).

Paratype MB.C.3662: incomplete specimen with $33 \mathrm{~mm}$ conch diameter in iron-rich micritic limestone; the specimen is filled with sparry calcite. The specimen is fully chambered, body chamber missing.

Paratype MB.C.22161: fairly well-preserved specimen with $65 \mathrm{~mm}$ conch diameter in haematitic limestone. The specimen is broken apart and allows the study of an inner whorl and its suture line (Figs 10B, 11A).
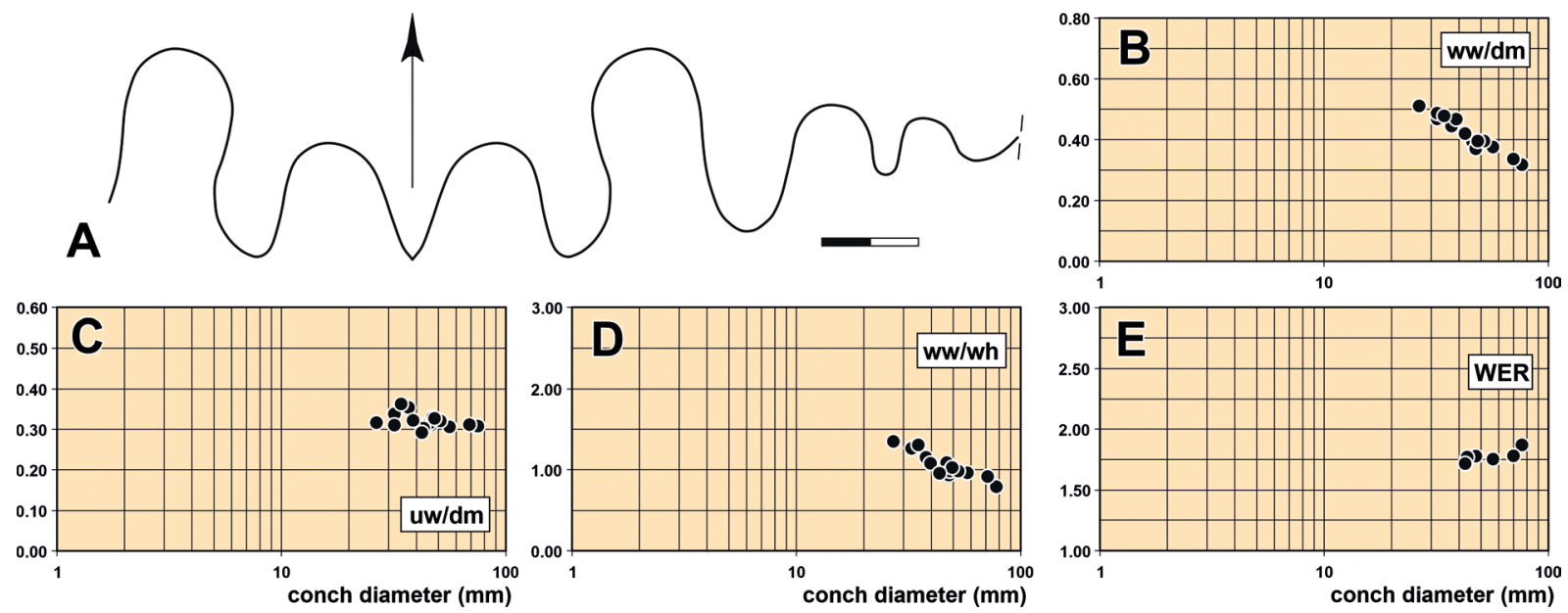

Fig. 11. Pharciceras oberscheldense Bockwinkel \& Korn in Bockwinkel et al., 2013. A. Suture line of paratype MB.C.22161 (Krüger 1873 Coll.), at wh=12.9 mm. B-E. Ontogeneric trajectories of the cardinal conch parameters. Abbreviation: see Material and methods. Scale bar units $=1 \mathrm{~mm}$.

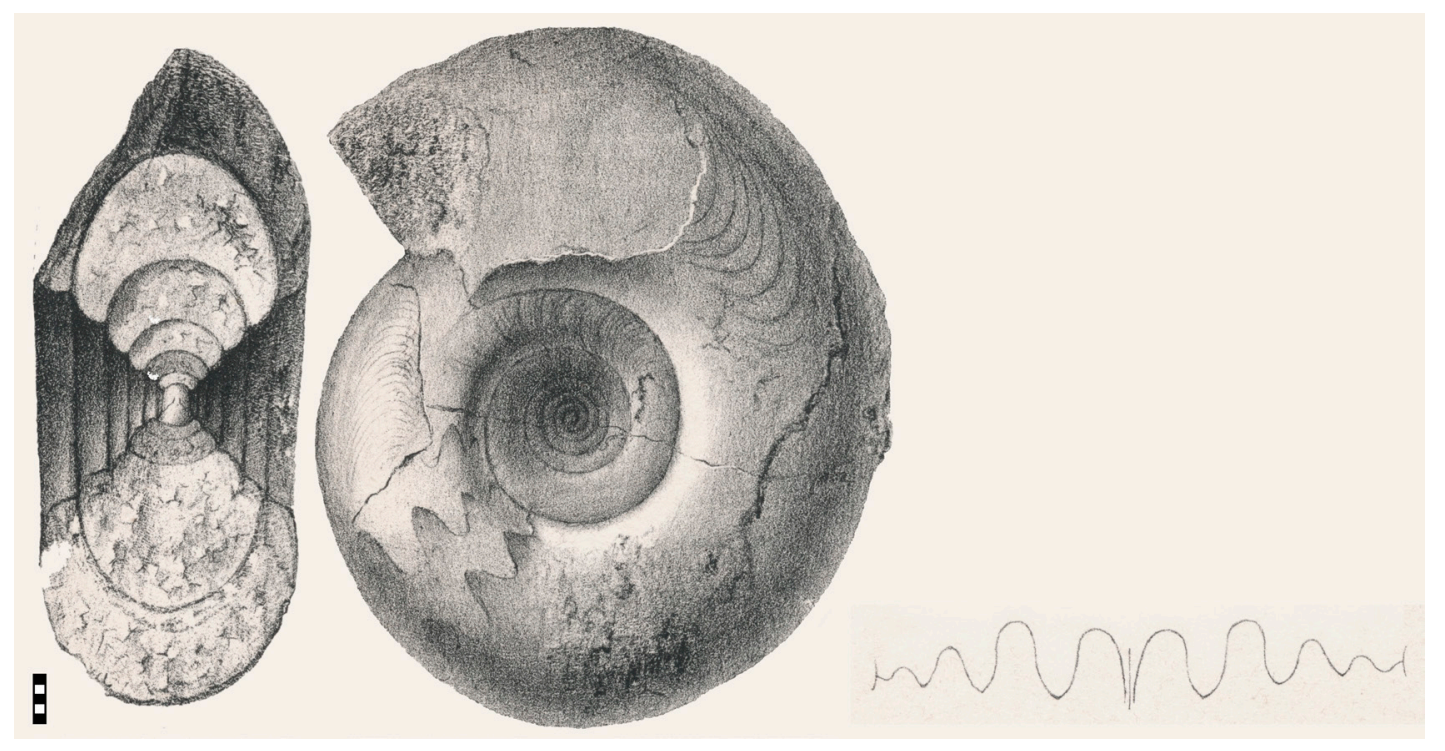

Fig. 12. Pharciceras oberscheldense Bockwinkel \& Korn in Bockwinkel et al., 2013, reproduction of the specimen illustrated in Frech (1888: pl. 2 fig. 5). Scale bar units $=1 \mathrm{~mm}$. 
Paratype MB.C.22168: incomplete steinkern specimen with $47 \mathrm{~mm}$ conch diameter in iron-rich limestone; the complete last volution belongs to the body chamber (Fig. 10C).

Specimens SMF.Mbg.6362-6364: three specimens between 32 and $43 \mathrm{~mm}$ conch diameter in iron-rich limestone (Fig. 10E-G).

Hototype MB.C.3620 has in the last volution at $76 \mathrm{~mm}$ diameter a discoidal and subevolute conch $(\mathrm{ww} / \mathrm{dm}=0.32 ; \mathrm{uw} / \mathrm{dm}=0.31)$ with moderately high coiling rate $(\mathrm{WER} \sim 1.87)$; the whorl profile is compressed $(\mathrm{ww} / \mathrm{wh}=0.77)$ with narrow umbilical wall and slightly flattened flanks which converge towards the subangular ventrolateral shoulder. In the penultimate whorl, the venter is broadly rounded. Here, two shallow ventrolateral spiral grooves are accompanied by low ridges on each side. Lamellose growth lines are well-preserved here and extend with a wide dorsolateral projection, a broad lateral sinus, and a very pronounced, narrow ventrolateral projection across the flanks. The suture line has, at approximately $34 \mathrm{~mm}$ conch diameter, a very wide external lobe, in which the prongs are slightly pouched. Two V-shaped lobes are located on the flank (Fig. 11A), a narrowly rounded $\mathrm{U}_{2}$ and a shallow and wide $\mathrm{A}_{4}$ lobe.

The smaller paratypes confirm the morphology visible in the penultimate whorl of the holotype. They show that, between 28 and $60 \mathrm{~mm}$ conch diameter, the conch shape becomes slenderer (ww/ $\mathrm{dm}$ reduced from $\sim 0.45$ to $\sim 0.30$ ), while the umbilical width ratio is rather stable (uw $/ \mathrm{dm}=0.30-0.35$ ).

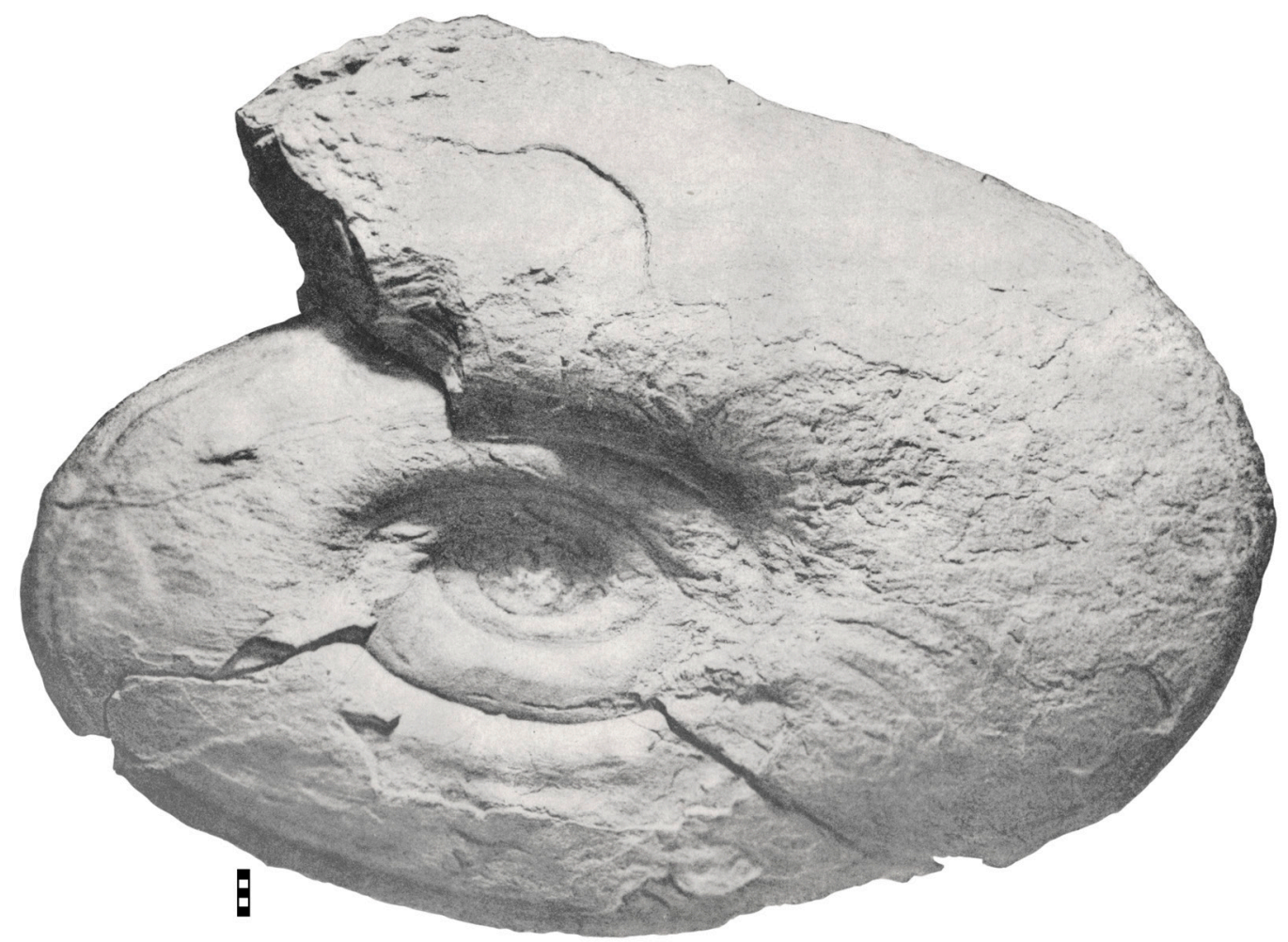

Fig. 13. Pharciceras oberscheldense Bockwinkel \& Korn in Bockwinkel et al., 2013, the probably lost specimen figured by Wedekind (1918: pl. 20 fig. 7) as Pharciceras tridens (Sandberger \& Sandberger, 1850) from Langenaubach (Constanze Mine). Scale bar units $=1 \mathrm{~mm}$. 
Table 4. Conch dimensions and ratios of selected specimens of Pharciceras oberscheldense Bockwinkel \& Korn in Bockwinkel et al., 2013.

\begin{tabular}{ccccccccccc}
\hline Specimen & $\mathbf{d m}$ & $\mathbf{w w}$ & $\mathbf{w h}$ & $\mathbf{u w}$ & $\mathbf{a h}$ & $\mathbf{w w} / \mathbf{d m}$ & $\mathbf{w w} / \mathbf{w h}$ & $\mathbf{u w} / \mathbf{d m}$ & $\mathbf{W E R}$ & IZR \\
\hline MB.C.3620 & 76.2 & 24.2 & 31.3 & 23.4 & 20.5 & 0.32 & 0.77 & 0.31 & 1.87 & 0.35 \\
MB.C.22161 & 69.8 & 23.5 & 26.0 & 21.7 & 17.5 & 0.34 & 0.90 & 0.31 & 1.78 & 0.33 \\
MB.C.22168 & 48.5 & 19.2 & 18.9 & 15.8 & - & 0.40 & 1.02 & 0.33 & - & - \\
MB.C.3655 & 47.5 & 17.6 & 18.1 & 15.6 & 11.9 & 0.37 & 0.97 & 0.33 & 1.78 & 0.34 \\
SMF.Mbg.6363 & 42.6 & 17.9 & 19.0 & 12.4 & 10.1 & 0.42 & 0.94 & 0.29 & 1.72 & 0.47 \\
SMF.Mbg.6362 & 34.3 & 16.4 & 12.6 & 12.4 & - & 0.48 & 1.30 & 0.36 & - & - \\
SMF.Mbg.6364 & 32.0 & 15.6 & 12.4 & 9.9 & - & 0.49 & 1.26 & 0.31 & - & - \\
MB.C.3662 & 26.6 & 13.6 & 10.1 & 8.4 & - & 0.51 & 1.35 & 0.32 & - & - \\
\hline
\end{tabular}

Table 5. Conch ontogeny of Pharciceras oberscheldense Bockwinkel \& Korn in Bockwinkel et al., 2013.

\begin{tabular}{cccc}
\hline $\mathbf{d m}$ & conch shape & whorl cross section shape & whorl expansion \\
\hline \multirow{2}{*}{$30 \mathrm{~mm}$} & thickly discoidal; subevolute & weakly depressed; strongly embracing & low \\
& $(\mathrm{ww} / \mathrm{dm} \sim 0.48 ; \mathrm{uw} / \mathrm{dm} \sim 0.30)$ & $(\mathrm{ww} / \mathrm{wh} \sim 1.30 ;$ IZR $\sim 0.30)$ & $(\mathrm{WER} \sim 1.70)$ \\
\hline \multirow{2}{*}{$50 \mathrm{~mm}$} & thinly discoidal; subevolute & weakly compressed; strongly embracing & moderate \\
& $(\mathrm{ww} / \mathrm{dm} \sim 0.38 ; \mathrm{uw} / \mathrm{dm} \sim 0.30)$ & $(\mathrm{ww} / \mathrm{wh} \sim 0.95 ;$ IZR $\sim 0.30)$ & $(\mathrm{WER} \sim 1.75)$ \\
\hline \multirow{2}{*}{$75 \mathrm{~mm}$} & $\begin{array}{c}\text { extremely discoidal; subevolute } \\
(\mathrm{ww} / \mathrm{dm} \sim 0.30 ; \mathrm{uw} / \mathrm{dm} \sim 0.30)\end{array}$ & $\begin{array}{c}\text { weakly compressed; strongly embracing } \\
\text { (ww/wh } \sim 0.80 ; \text { IZR } \sim 0.30)\end{array}$ & $\begin{array}{c}\text { moderate } \\
(\text { WER } \sim 1.85)\end{array}$ \\
\hline
\end{tabular}

\section{Remarks}

Pharciceras oberscheldense is a common species in the Red Ironstone from Dillenburg and specimens of this species were obviously often referred to as $P$. tridens. This includes the specimen figured by Frech (1888), which cannot be assigned to P. tridens because of its rather narrow umbilicus, which has only one third of the conch diameter (Fig. 12) and probably also the specimen figured by Wedekind (1918: pl. 20 fig. 7) (Fig. 13).

Pharciceras oberscheldense belongs to the more narrowly umbilicate species of the genus (uw/dm $\sim 0.30$ at $30-40 \mathrm{~mm} \mathrm{dm}$ ) and differs in this respect from $P$. tridens and $P$. kochi sp. nov. (uw/ dm $\sim 0.40$ ). Among the narrowly umbilicate species of Pharciceras, P. oberscheldense differs from $P$. ferrum sp. nov. in the shape of the lateral lobe (rounded in P. oberscheldense but V-shaped in P. ferrum sp. nov.) and in the wider whorl profile (ww/wh $\sim 1.05$ at $50 \mathrm{~mm}$ dm in $P$. oberscheldense but only $\sim 0.80$ in P. ferrum sp. nov.).

Pharciceras tridens (Sandberger \& Sandberger, 1850) Figs 14-16; Tables 6-7

Goniatites tridens Sandberger \& Sandberger, 1850: 66, pl. 4 fig. 2.

Pharciceras tridens - Hyatt 1884: 336. — Matern 1931: 93. — Korn \& Klug 2002: text-fig. 131. Prolecanites tridens - Frech 1897: 177e, figs 1f, 2a; 1902: 64, text-fig. 21a, pl. 3 fig. 12.

non Goniatites tridens Sandberger \& Sandberger 1850: pl. 9 fig. 2.

non Pharciceras tridens - Frech 1888: 29, pl. 2 fig. 5. - Wedekind 1918: 128, text-fig. 37a. — Korn \& Klug 2002: text-fig. 134a, $\mathrm{h}$. 
? Pharciceras tridens - Termier \& Termier 1950: pl. 150 figs 31-32, 34-36. - Petter 1959: 133, pl. 7 figs 10, 12, 12a, text-figs 18, 33k. - Bogoslovsky 1969: pl. 26 fig. 1, text-fig. 69b. - Kullmann \& Ziegler 1970: 77, pl. 1 figs 2-3, text-figs 2a, 3a, 4. — Bensaïd 1974: 110, pl. 4 fig. 8 , pl. 5 fig. 11, text-figs 7, 18, 19c. — Göddertz 1987: 181, pl. 13 figs 3-4, text-fig. 29. — Bockwinkel et al. 2009: 76 , text-figs $6 \mathrm{a}-\mathrm{g}, 7 \mathrm{a}$.

\section{Diagnosis}

Species of Pharciceras with thinly discoidal, subevolute conch at $30 \mathrm{~mm} \mathrm{dm} \mathrm{(ww/dm} \sim 0.45 ; \mathrm{uw} / \mathrm{dm}$ $\sim 0.42$ ) and thinly discoidal, subevolute conch at $50 \mathrm{~mm} \mathrm{dm} \mathrm{(ww/dm} \sim 0.40 ; \mathrm{uw} / \mathrm{dm} \sim 0.40)$. Whorl profile weakly depressed at $30 \mathrm{~mm} \mathrm{dm}$ (ww/wh $\sim 1.45)$ and weakly depressed at $50 \mathrm{~mm} \mathrm{dm} \mathrm{(ww/wh}$ 1.20); whorl expansion rate low to moderate. Venter continuously rounded. Growth lines coarse, strongly biconvex; ventrolateral shoulder with two spiral grooves. Outer suture line with symmetric, lanceolate prongs of the external lobe, a tongue-shaped lateral lobe, a narrow $\mathrm{U}$-shaped $\mathrm{U}_{2}$ lobe, and a shallow and wide $\mathrm{U}_{4}$ lobe.

\section{Material examined}

\section{Lectotype}

GERMANY • Rhenish Mountains, Oberscheld; late Givetian (Red Ironstone); nr. 29 (Wiesbaden Museum); illustrated by Sandberger \& Sandberger (1850-1856: pl. 4 fig. 2), re-illustrated here in Fig. 14; Wiesbaden Museum nr. 29.

\section{Additional material}

GERMANY • 5 specimens; Rhenish Mountains, Oberscheld (Westfeld der Grube Königszug, Firste der 120-150 m Sohle); late Givetian (Red Ironstone); Ahlburg Coll.; MB.C.3618, MB.C.3634, MB.C.3647, MB.C.3663, MB.C.3670 • 1 specimen; Rhenish Mountains, Oberscheld (Grube Anna); late Givetian (Red Ironstone); Koch Coll.; MB.C.3638.

\section{Description}

Five specimens are selected for description and illustration:

Lectotype 29 in the Wiesbaden Museum: Rather poorly preserved, corroded specimen with $26 \mathrm{~mm}$ conch diameter in iron-rich limestone (Fig. 14).

MB.C.3618: incomplete specimen with $54 \mathrm{~mm}$ conch diameter in iron-rich micritic limestone (Fig. 15A).

MB.C.3647: incomplete specimen with $46 \mathrm{~mm}$ conch diameter in iron-rich micritic limestone with body chamber occupying the last volution (Fig. 15B).

MB.C.3663: Fully chambered but widely covered with shell, incomplete specimen with $31 \mathrm{~mm}$ conch diameter in micritic, haematitic limestone, largely filled with sparry calcite (Fig. 15C).

MB.C.3634: incomplete specimen with $27 \mathrm{~mm}$ conch diameter in micritic, haematitic limestone (Fig. 15D).

Lectotype 29 is a specimen of less than $30 \mathrm{~mm}$ diameter and allows the study of conch shape and suture line of the preadult stage. The conch is discoidal and subevolute with a crescent-shaped whorl profile. The shell is largely removed and only at some parts preserved with rather coarse growth lines. The suture line has U-shaped prongs of the external lobe and a tongue-shaped lateral lobe. 
The four specimens MB.C.3634, MB.C.3663, MB.C.3647 and MB.C.3618 allow the study of conch geometry, ornament and suture line between 27 and $57 \mathrm{~mm}$ conch diameter. The general conch morphology is similar during this interval, but the conchs become slenderer (ww/ $\mathrm{dm}$ decreasing from $\sim 0.47$ to $\sim 0.39$ ), paralleled by flattening of the whorl profile (ww/wh decreasing from $\sim 1.45$ to $\sim 1.20$ ). All specimens show double ventrolateral grooves.

Specimen MB.C.3618 shows the suture line, which has a very wide external lobe with a median saddle attaining about $60 \%$ of the lobe depth and lanceolate prongs. The lateral lobe is much shorter than the external lobe; it is tongue-shaped with a narrowly rounded base. On the flanks and umbilical margin follow two very small, rounded umbilical lobes (Fig. 16A).

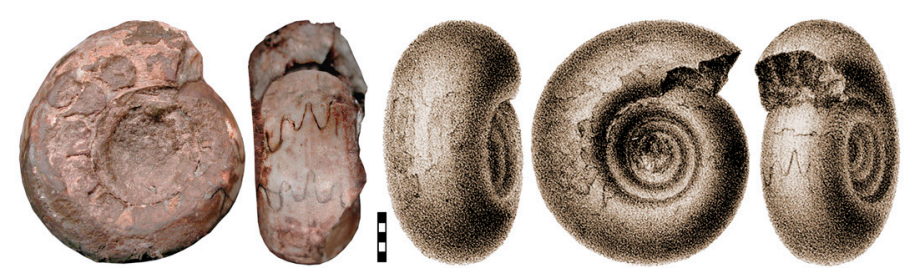

Fig. 14. Pharciceras tridens (Sandberger \& Sandberger, 1850), lectotype 29 (Wiesbaden Museum) from Oberscheld; photograph and reproduction of the figure in Sandberger \& Sandberger (1850-1856: pl. 4 fig. 2). Scale bar units $=1 \mathrm{~mm}$.
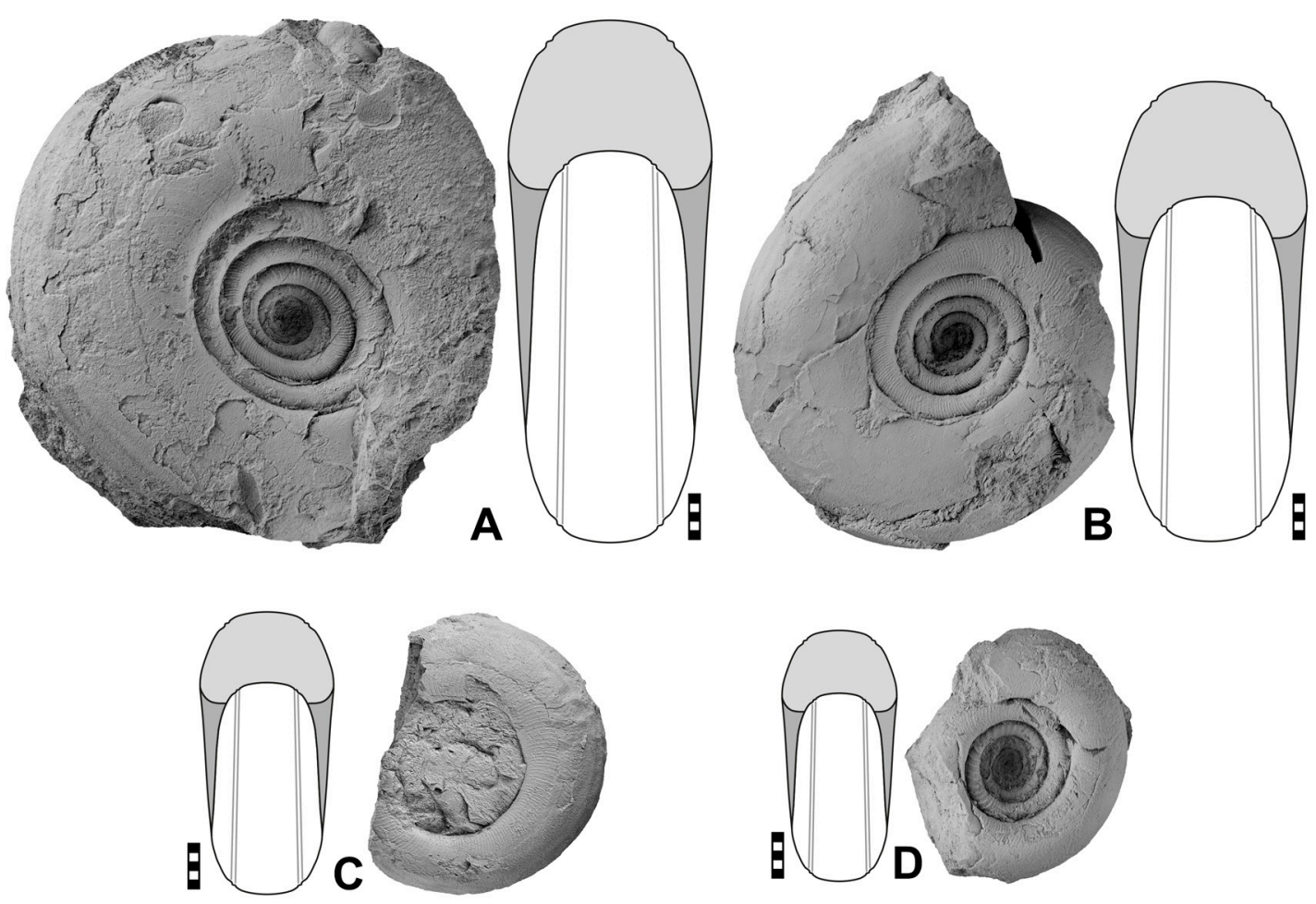

Fig. 15. Pharciceras tridens (Sandberger \& Sandberger, 1850). A. Specimen MB.C.3618 (Ahlburg Coll.) from Oberscheld (Königszug Mine). B. Specimen MB.C.3647 (Ahlburg Coll.) from Oberscheld (Königszug Mine). C. Specimen MB.C.3663 (Ahlburg Coll.) from Oberscheld (Königszug Mine). D. Specimen MB.C.3634 (Ahlburg Coll.) from Oberscheld (Königszug Mine). Scale bar units $=1 \mathrm{~mm}$. 
Table 6. Conch dimensions (partly reconstructed) and ratios of selected specimens of Pharciceras tridens (Sandberger \& Sandberger, 1850).

\begin{tabular}{ccccccccccc}
\hline Specimen & dm & ww & wh & uw & ah & ww/dm & ww/wh & uw/dm & WER & IZR \\
\hline MB.C.3618 & 57.3 & 22.3 & 18.6 & 23.7 & 14.2 & 0.39 & 1.20 & 0.41 & 1.76 & 0.24 \\
MB.C.3647 & 50.5 & 21.0 & 17.2 & 20.0 & 12.9 & 0.42 & 1.22 & 0.40 & 1.80 & 0.25 \\
MB.C.3663 & 31.0 & 14.7 & 10.1 & 13.7 & 7.3 & 0.47 & 1.45 & 0.44 & 1.71 & 0.28 \\
MB.C.3634 & 27.6 & 12.6 & 9.0 & 11.5 & 6.8 & 0.46 & 1.41 & 0.42 & 1.77 & 0.24 \\
Lectotype 29 & 25.6 & 12.1 & 7.2 & 11.3 & 5.6 & 0.47 & 1.68 & 0.44 & 1.64 & 0.22 \\
\hline
\end{tabular}

Table 7. Conch ontogeny of Pharciceras tridens (Sandberger \& Sandberger, 1850).

\begin{tabular}{cccc}
\hline $\mathbf{d m}$ & conch shape & whorl cross section shape & whorl expansion \\
\hline \multirow{2}{*}{$30 \mathrm{~mm}$} & thinly discoidal; subevolute & weakly depressed; moderately embracing & low \\
& $(\mathrm{ww} / \mathrm{dm} \sim 0.45 ;$ uw $/ \mathrm{dm} \sim 0.42)$ & $($ ww $/$ wh $\sim 1.45 ;$ IZR $\sim 0.25)$ & (WER $\sim 1.70)$ \\
\hline \multirow{2}{*}{$50 \mathrm{~mm}$} & thinly discoidal; subevolute & weakly depressed; moderately embracing & moderate \\
& $(\mathrm{ww} / \mathrm{dm} \sim 0.40 ;$ uw $/ \mathrm{dm} \sim 0.40)$ & $($ ww $/ \mathrm{wh} \sim 1.20 ;$ IZR $\sim 0.25)$ & $($ WER $\sim 1.75)$ \\
\hline
\end{tabular}

\section{Remarks}

Unfortunately, the lectotype of Pharciceras tridens is a rather small and poorly preserved specimen with only $26 \mathrm{~mm}$ conch diameter (Fig. 14); therefore, it may be difficult to compare this with the other species of the genus, which are defined by larger type material. The type specimen allows at least to figure two characters that can be used to characterise the species, the first is the rather wide umbilicus (uw/dm $\sim 0.40$ ) and the tongue-shaped, rounded or blunt lateral lobe.

Only one species from the Red Ironstone has an umbilicus as wide as that in $P$. tridens, it is $P$. beyrichi sp. nov. but this differs in its much stouter conch with a much broader whorl profile (ww/ $\mathrm{dm} \sim 0.45$ and
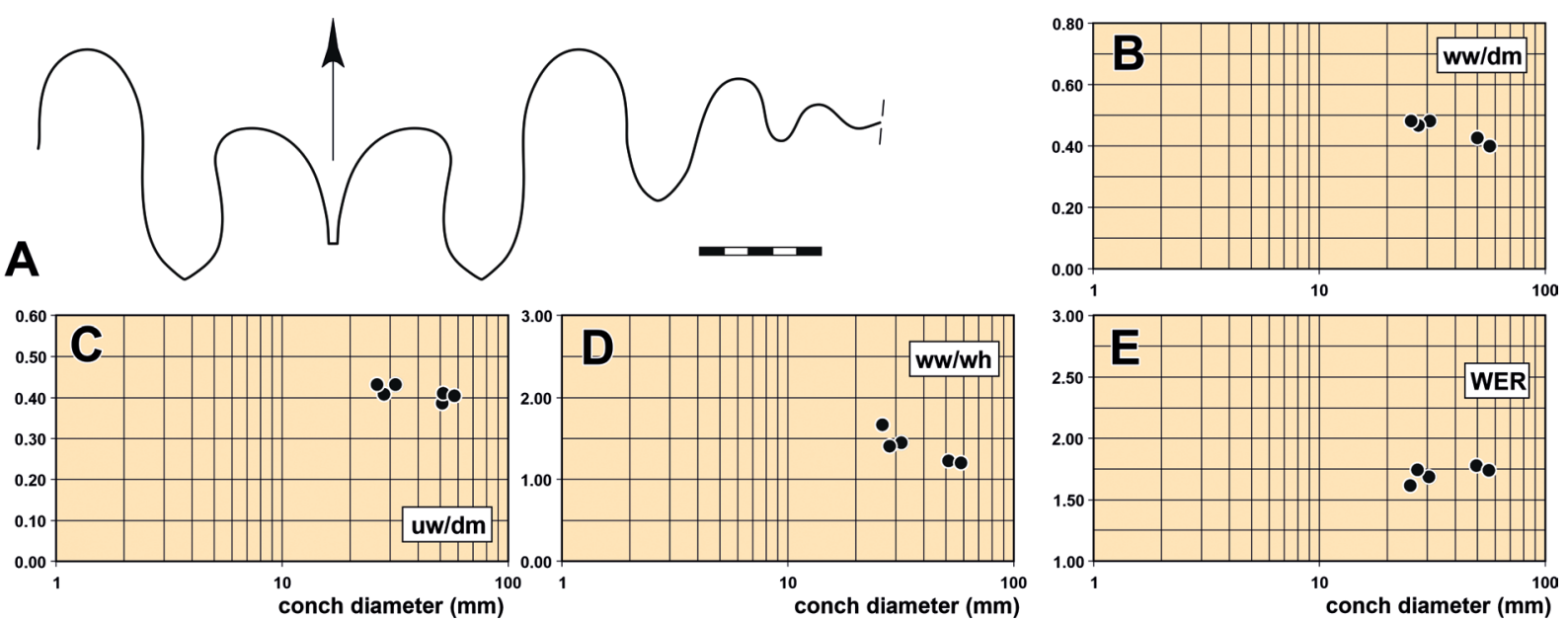

Fig. 16. Pharciceras tridens (Sandberger \& Sandberger, 1850). A. Suture line of specimen MB.C.3618 (Ahlburg Coll.) from Oberscheld (Königszug Mine), at $\mathrm{dm}=48.5 \mathrm{~mm}, w w=19.0 \mathrm{~mm}$, wh $=18.0 \mathrm{~mm}$. B-E. Ontogeneric trajectories of the cardinal conch parameters. Abbreviations: see Material and methods. Scale bar units $=1 \mathrm{~mm}$. 
ww/wh $\sim 1.40$ in P. tridens but ww/ dm $\sim 0.55$ and ww/wh $\sim 1.75$ in P. beyrichi sp. nov.). Furthermore, the ventrolateral grooves are much deeper in $P$. beyrichi sp. nov.

The species name Pharciceras tridens has frequently been used in the past decades for all specimens with a rather wide umbilicus and little differentiated suture line. For a secure classification of these specimens, a comprehensive revision would be necessary, which, however, is outside the scope of the present study. These mentions in the literature are therefore marked with a question mark in the list of synonyms.

Pharciceras kayseri Wedekind, 1918

Figs 17-19; Tables 8-9

Pharciceras Kayseri Wedekind, 1918: 127, 169, pl. 20 fig. 2, text-fig. 37c1-c2.

Pharciceras kayseri - Matern 1931: 92.

non Pharciceras kayseri - Petter 1959: 134, pl. 7 figs 1, 14, text-fig. 33j. — Kullmann \& Ziegler 1970: 78, pl. 1 fig. 4, text-figs 2b, 3b, 4. — Bockwinkel et al. 2009: 93, text-figs 10g, 16.

\section{Diagnosis}

Pharciceras with thinly discoidal, subinvolute conch at $30 \mathrm{~mm} \mathrm{dm} \mathrm{(ww/dm} \sim 0.45 ; \mathrm{uw} / \mathrm{dm} \sim 0.28$ ); extremely discoidal, subinvolute at $60 \mathrm{~mm} \mathrm{dm}$ (ww $/ \mathrm{dm} \sim 0.30$; uw $/ \mathrm{dm} \sim 0.25$ ). Whorl profile compressed at $30 \mathrm{~mm} \mathrm{dm}(\mathrm{ww} / \mathrm{wh} \sim 0.95)$ and rounded-triangular, compressed at $60 \mathrm{~mm} \mathrm{dm} \mathrm{(ww/wh}$ $\sim 0.70$ ); whorl expansion rate low to moderate. Preadult and adult stages with broadly convex, strongly converging flanks continuing to the very narrowly rounded venter. Growth lines fine, strongly biconvex; ventrolateral shoulder with two faint spiral grooves. Outer suture line with short pointed $\mathrm{E}_{1}$, symmetric, narrowly V-shaped prongs of the external lobe, a small, V-shaped lateral lobe and a very small V-shaped $\mathrm{U}_{2}$ lobe.

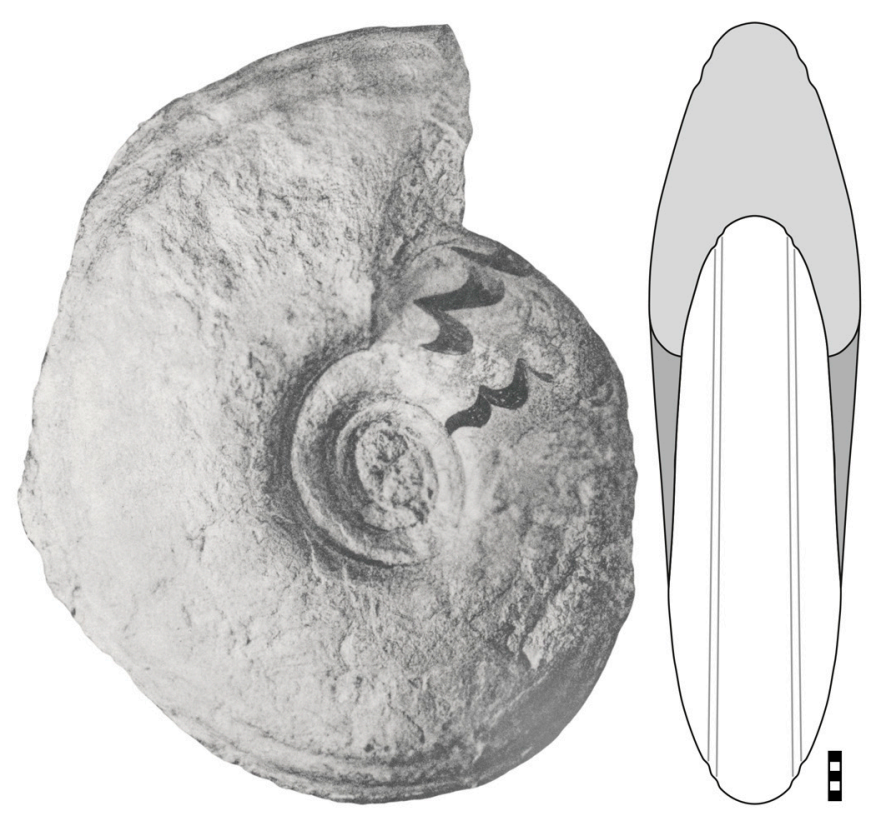

Fig. 17. Pharciceras kayseri Wedekind, 1918, specimen SMF.Mbg.2317 (Welsch 1913 Coll.) from Oberscheld (Prinzkessel Mine), reproduction from Wedekind (1918: pl. 20 fig. 2). Scale bar units = $1 \mathrm{~mm}$. 


\section{Material examined}

\section{Holotype}

GERMANY • Rhenish Mountains, Oberscheld (Grube Prinzkessel); late Givetian (Red Ironstone); Welsch 1913 Coll.; illustrated by Wedekind (1918: pl. 20 fig. 2), re-illustreted here in Fig. 17; SMF.Mbg.2317.

\section{Additional material}

GERMANY - 3 specimens; Rhenish Mountains, Oberscheld (Westfeld der Grube Königszug, Firste der 120-150 m Sohle); late Givetian (Red Ironstone); Ahlburg Coll.; MB.C.3621, MB.C.3622, MB.C.3630 1 specimen; Rhenish Mountains, Dillenburg; late Givetian (Red Ironstone); Krüger 1873 Coll.; MB.C.22172 - 2 specimens; Rhenish Mountains, probably a mine near Oberscheld; late Givetian (Red Ironstone); Krüger 1873 Coll.; MB.C.30235.1, MB.C.30235.2.

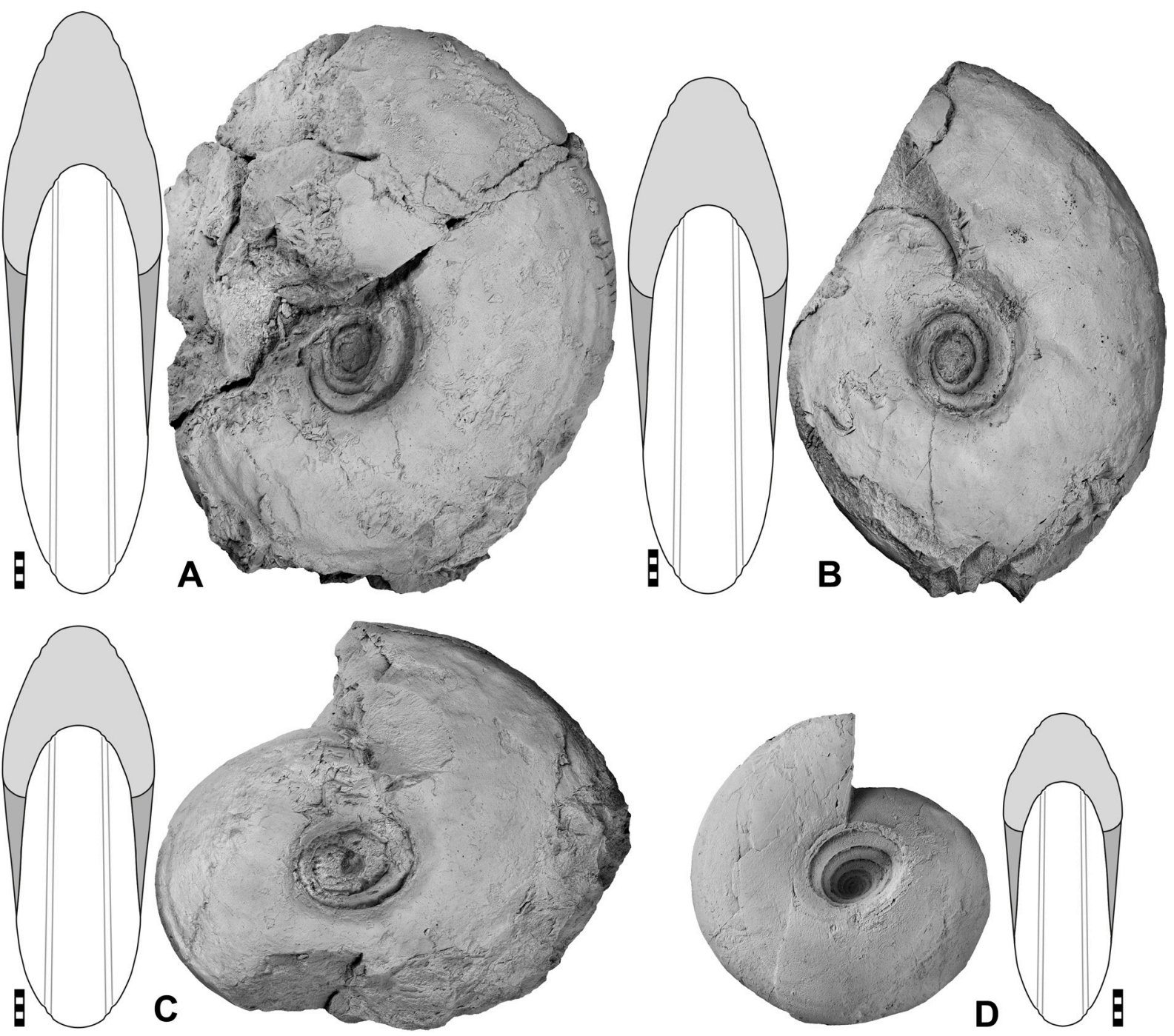

Fig. 18. Pharciceras kayseri Wedekind, 1918. A. Specimen MB.C.3630 (Ahlburg Coll.) from Oberscheld (Königszug Mine). B. Specimen MB.C.30235.1, probably from Oberscheld. C. Specimen MB.C.30235.2, probably from Oberscheld. D. Specimen MB.C.22172 (Krüger 1873 Coll.) from Dillenburg. Scale bar units $=1 \mathrm{~mm}$. 


\section{Description}

Five specimens are selected for description and illustration:

Holotype SMF.Mbg.2317: rather well-preserved specimen with $80 \mathrm{~mm}$ conch diameter in haematitic limestone (Fig. 17).

MB.C.3630: incomplete specimen with $78 \mathrm{~mm}$ conch diameter in haematitic, micritic limestone (Fig. 18A).

MB.C.30235.1: deformed specimen with $71 \mathrm{~mm}$ conch diameter in haematitic, micritic limestone, showing the suture line (Fig. 18B).

MB.C.30235.2: deformed specimen with $64 \mathrm{~mm}$ conch diameter in haematitic, micritic limestone, showing parts of the suture line (Fig. 18C).

MB.C.22172: strongly deformed specimen with $42 \mathrm{~mm}$ conch diameter in haematitic iron-ore (Fig. 18D).

The material allows the description of conch geometry and ornament of the growth interval between 42 and $80 \mathrm{~mm}$ conch diameter. In this interval, the conch becomes slenderer (ww/wh decreases from $\sim 0.42$ to $\sim 0.28$ ), while the umbilical opening rate is rather constant (uw/ $\mathrm{dm} \sim 0.25$ ). The coiling rate increases slowly form WER $\sim 1.70$ to $\sim 1.85$. The whorl profile is rounded triangular, it is widest near the rounded umbilical margin. The flanks are weakly convex and converge towards the narrowly rounded venter. Two faint ventrolateral grooves are present in all specimens. Shell remains are preserved only occasionally; it appears that the growth lines are very delicate, even in the inner whorls.

The suture line of specimen MB.C.30235.1 has a large external lobe with a median saddle raised to three quarters of the lobe depth (Fig. 19A). On the flanks, there is a rather small, V-shaped lateral lobe and an even much smaller, V-shaped umbilical lobe.

\section{Remarks}

Pharciceras kruegeri $\mathrm{sp}$. nov. is a similar species but differs in the stouter conch (ww/dm $\sim 0.40 ; \mathrm{ww} / \mathrm{wh}$ $\sim 1.05$ ) from $P$. kayseri ( $\mathrm{ww} / \mathrm{dm} \sim 0.30$; ww $/ \mathrm{wh} \sim 0.65$ ) at $60 \mathrm{~mm}$ diameter. The ornament reveals more
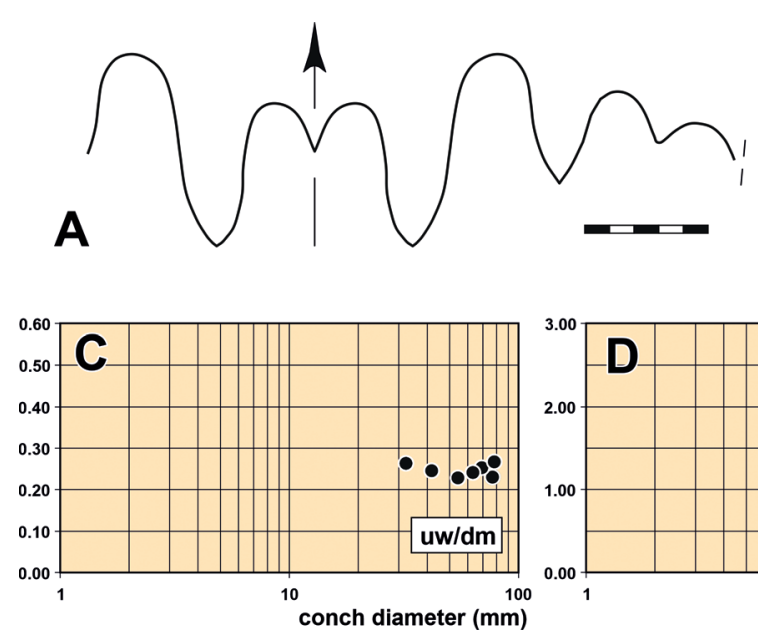
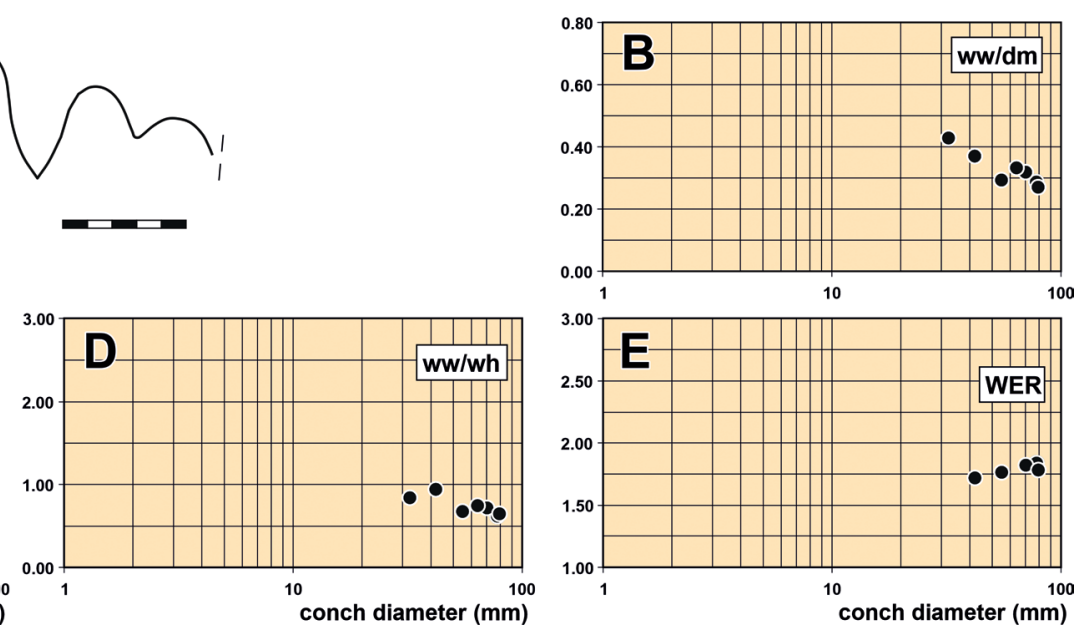

Fig. 19. Pharciceras kayseri Wedekind, 1918. A. Suture line of specimen MB.C.30235.1, probably from Oberscheld, at $w w=18.0 \mathrm{~mm}, w h=20.0 \mathrm{~mm}$. B-E. Ontogeneric trajectories of the cardinal conch parameters. Abbreviations: see Material and methods. Scale bar units $=1 \mathrm{~mm}$. 
Table 8. Conch dimensions and ratios of selected specimens of Pharciceras kayseri Wedekind, 1918.

\begin{tabular}{ccccccccccc}
\hline Specimen & dm & ww & wh & uw & ah & ww/dm & ww/wh & uw/dm & WER & IZR \\
\hline SMF.Mbg.2317 & 79.6 & 21.3 & 33.3 & 21.2 & 20.0 & 0.27 & 0.64 & 0.27 & 1.78 & 0.40 \\
MB.C.3630 & 78.1 & 22.2 & 36.4 & 17.9 & 20.5 & 0.28 & 0.61 & 0.23 & 1.84 & 0.44 \\
MB.C.30235.1 & 70.2 & 22.2 & 31.2 & 17.7 & 18.2 & 0.32 & 0.71 & 0.25 & 1.82 & 0.42 \\
MB.C.30235.2 & 64.0 & 21.1 & 28.5 & 15.4 & - & 0.33 & 0.74 & 0.24 & - & - \\
MB.C.3621 & 55.0 & 16.0 & 24.0 & 12.5 & 13.6 & 0.29 & 0.67 & 0.23 & 1.76 & 0.43 \\
MB.C.22172 & 42.1 & 15.5 & 16.5 & 10.3 & 10.0 & 0.37 & 0.94 & 0.24 & 1.72 & 0.39 \\
\hline
\end{tabular}

Table 9. Conch ontogeny of Pharciceras kayseri Wedekind, 1918.

\begin{tabular}{|c|c|c|c|}
\hline $\mathbf{d m}$ & conch shape & whorl cross section shape & whorl expansion \\
\hline $30 \mathrm{~mm}$ & $\begin{array}{l}\text { thinly discoidal; subinvolute } \\
\text { (ww/dm } \sim 0.45 ; \mathrm{uw} / \mathrm{dm} \sim 0.28 \text { ) }\end{array}$ & $\begin{array}{l}\text { weakly compressed; strongly embracing } \\
\quad \text { (ww/wh } \sim 0.90 ; \text { IZR } \sim 0.40 \text { ) }\end{array}$ & $\begin{array}{c}\text { low } \\
(\text { WER } \sim 1.70)\end{array}$ \\
\hline $50 \mathrm{~mm}$ & $\begin{array}{l}\text { extremely discoidal; subinvolute } \\
\text { (ww/dm } \sim 0.30 ; \mathrm{uw} / \mathrm{dm} \sim 0.25 \text { ) }\end{array}$ & $\begin{array}{l}\text { weakly compressed; strongly embracing } \\
\quad(\mathrm{ww} / \mathrm{wh} \sim 0.70 ; \mathrm{IZR} \sim 0.40)\end{array}$ & $\begin{array}{c}\text { moderate } \\
(\mathrm{WER} \sim 1.75)\end{array}$ \\
\hline $75 \mathrm{~mm}$ & $\begin{array}{l}\text { extremely discoidal; subinvolute } \\
\text { (ww/dm } \sim 0.27 ; \mathrm{uw} / \mathrm{dm} \sim 0.25 \text { ) }\end{array}$ & $\begin{array}{l}\text { weakly compressed; strongly embracing } \\
\quad(\mathrm{ww} / \mathrm{wh} \sim 0.65 ; \text { IZR } \sim 0.40)\end{array}$ & $\begin{array}{c}\text { moderate } \\
(\mathrm{WER} \sim 1.80)\end{array}$ \\
\hline
\end{tabular}

separating characters; it consists of very delicate growth lines in P. kayseri but coarse growth lines in P. kruegeri sp. nov.

Pharciceras ferrum sp. nov. is rather similar in conch proportions, but differs in less strongly convergent flanks and wider venter. P. galeatum is similar in the juvenile and preadult stage, but is more widely umbilicate and develops a tectifom venter in the adult stage.

The Moroccan specimens, placed in P. kayseri by Bockwinkel et al. (2009), differ in the suture line; they have short lobes of about the same height, while the Rhenish material has deep lobes of varying depth. Furthermore, the Moroccan specimens are stouter and the umbilicus is wider and the venter is not tabulate in $P$. kayseri.

Pharciceras kruegeri sp. nov.

urn:lsid:zoobank.org:act:CC6C112F-D0AB-41EE-AE54-45905BD1F6B2

Figs 20-22; Tables 10-11

\section{Diagnosis}

Species of Pharciceras with thinly pachyconic, subevolute conch at $30 \mathrm{~mm} \mathrm{dm}$ (ww/ $\mathrm{dm} \sim 0.62 ; \mathrm{uw} / \mathrm{dm}$ $\sim 0.35$ ); thinly discoidal, subinvolute at $60 \mathrm{~mm} \mathrm{dm}$ (ww/dm $\sim 0.40$; uw $/ \mathrm{dm} \sim 0.28$ ). Whorl profile depressed at $30 \mathrm{~mm} \mathrm{dm} \mathrm{(ww/wh} \sim 1.55)$ and rounded-triangular at $60 \mathrm{~mm} \mathrm{dm} \mathrm{(ww/wh} \sim 1.00)$; whorl expansion rate low to moderate. Preadult and adult stages with broadly convex flanks, strongly converging to the narrowly rounded venter. Growth lines coarse, strongly biconvex; ventrolateral shoulder with two faint spiral grooves. Outer suture line with symmetric, lanceolate prongs of the external lobe, a $\mathrm{U}$-shaped lateral lobe, a small $\mathrm{V}$-shaped $\mathrm{U}_{2}$ lobe and a shallow and wide $\mathrm{U}_{4}$ lobe.

\section{Etymology}

Named after the teacher Krüger (Hagen), who provided an important collection of fossils from the Red Ironstone. 


\section{Material examined}

\section{Holotype}

GERMANY • Rhenish Mountains, Oberscheld; late Givetian (Red Ironstone); Krüger 1873 Coll.; MB.C.22170. (Fig. 20A)

\section{Paratypes}

GERMANY - 1 specimen; Rhenish Mountains, Oberscheld; late Givetian (Red Ironstone); Krüger 1873 Coll.; MB.C.22162 • 1 specimen; Rhenish Mountains, Oberscheld (Tiefe Grube); late Givetian (Red Ironstone); Etzold 1910 Coll.; MB.C.3654 • 1 specimen; Rhenish Mountains, Langenaubach (Grube Constanze); late Givetian (Red Ironstone); Koch Coll.; MB.C.22163 • 1 specimen; Rhenish Mountains, Oberscheld; late Givetian (Red Ironstone); Dannenberg Coll.; MB.C.22198 • 1 specimen; Rhenish Mountains, Weilburg (Grube Georg-Joseph); late Givetian (Red Ironstone); Menk 1914
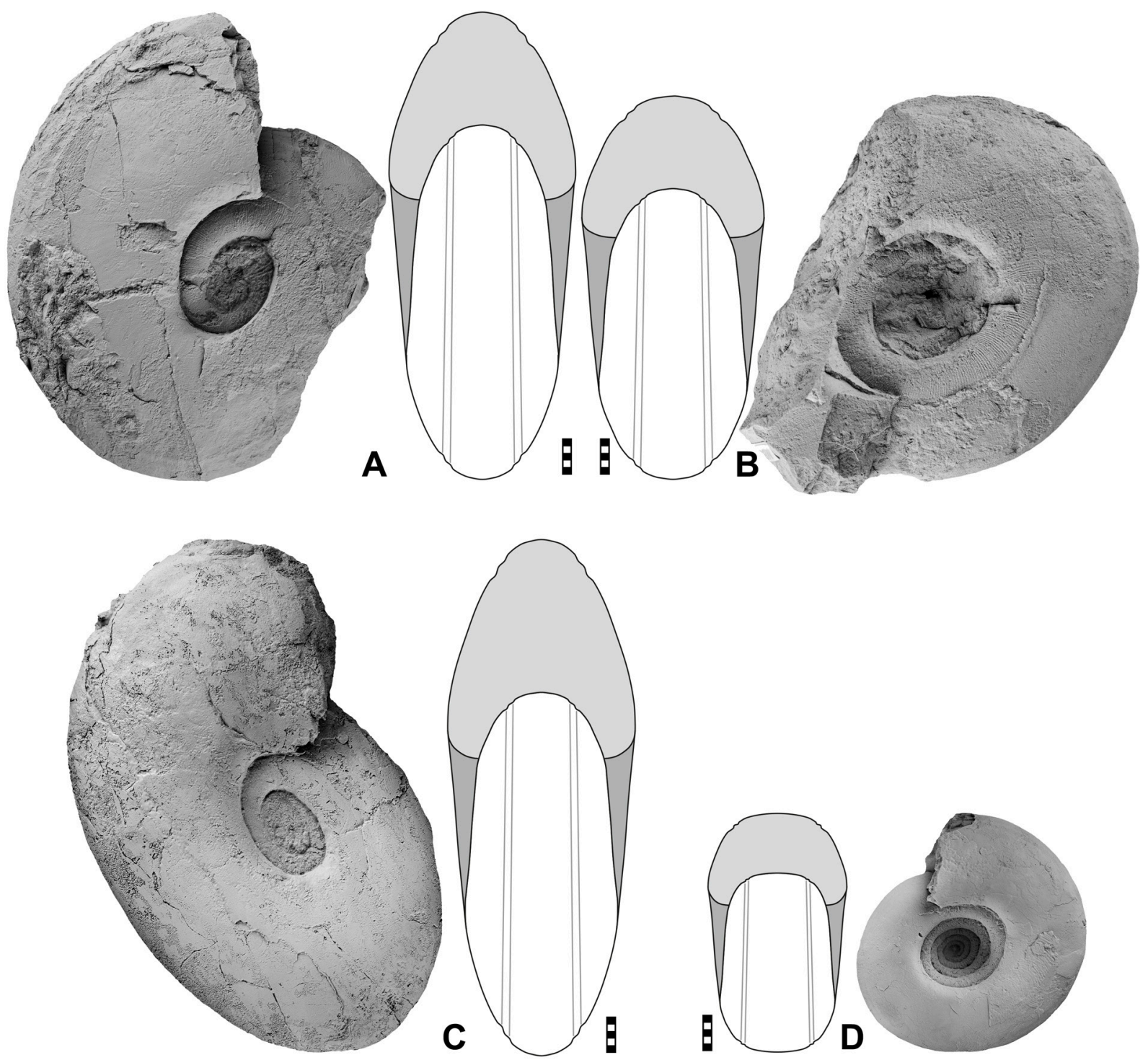

Fig. 20. Pharciceras kruegeri sp. nov. A. Holotype MB.C.22170 (Krüger 1873 Coll.) from Oberscheld. B. Paratype MB.C.22162 (Krüger 1873 Coll.) from Oberscheld. C. Paratype MB.C.22163 (Koch Coll.) from Langenaubach (Constanze Mine). D. Paratype MB.C.3654 (Etzold 1910 Coll.) from Oberscheld ('Tiefe Grube'). Scale bar units $=1 \mathrm{~mm}$. 


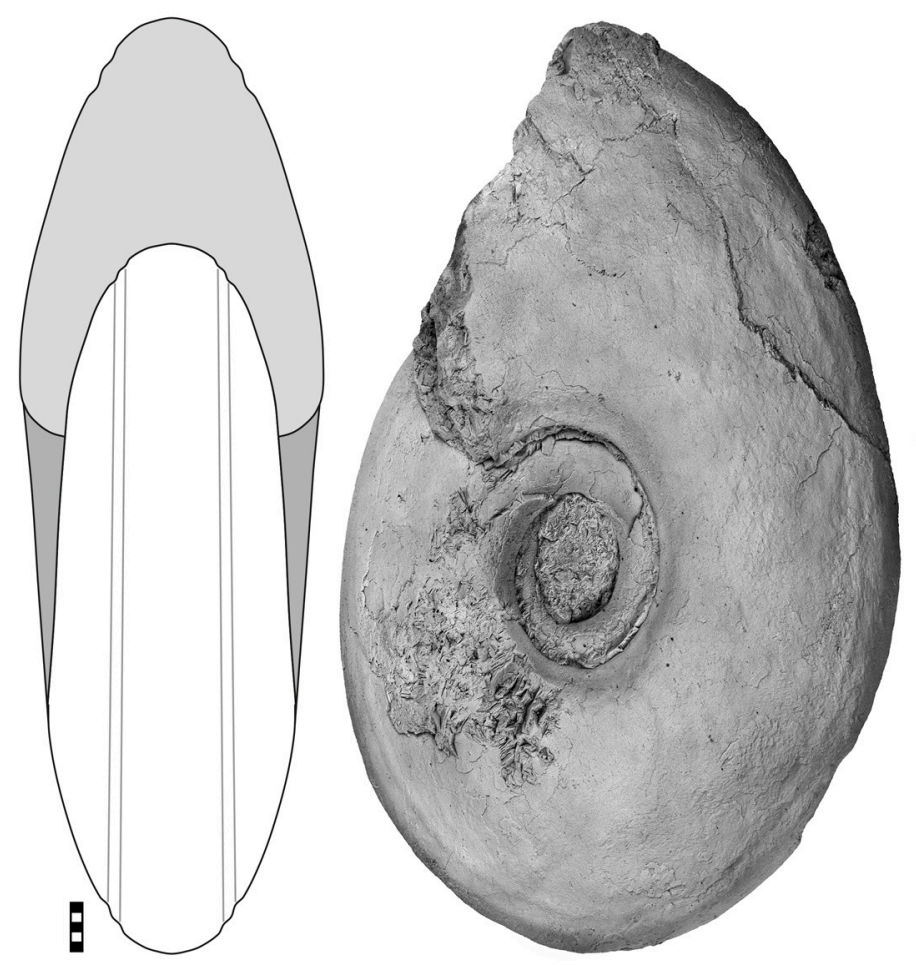

Fig. 21. Pharciceras kruegeri sp. nov., large paratype SMF.Mbg.6359 from Oberscheld. Scale bar units $=1 \mathrm{~mm}$.
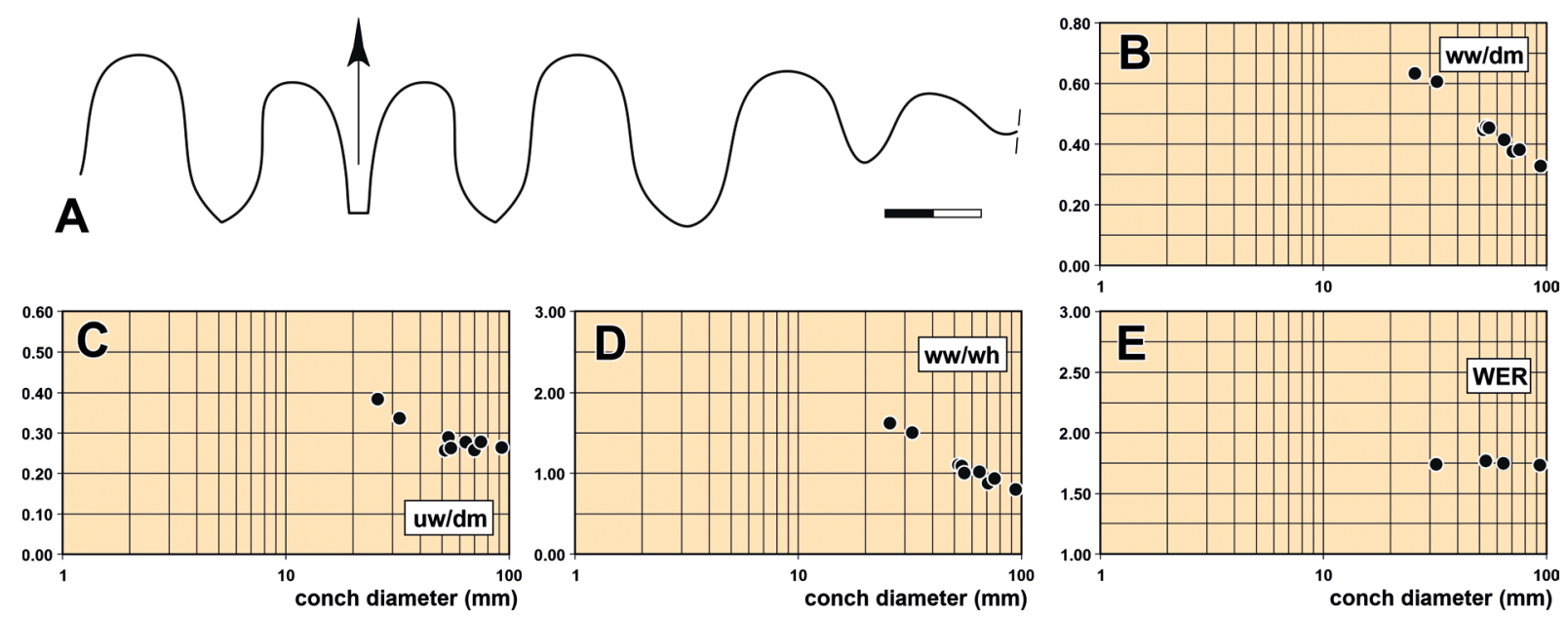

Fig. 22. Pharciceras kruegeri sp. nov. A. Suture line of paratype MB.C.3654 (Etzold 1910 Coll.) from Oberscheld ('Tiefe Grube'), at $\mathrm{dm}=20 \mathrm{~mm}$, ww $=15.5 \mathrm{~mm}$, wh $=6.5 \mathrm{~mm}$. B-E. Ontogeneric trajectories of the cardinal conch parameters. Abbreviations: see Material and methods. Scale bar units $=1 \mathrm{~mm}$. 
Coll.; MB.C.30236 • 1 specimen; Rhenish Mountains, Oberscheld; late Givetian (Red Ironstone); SMF.Mbg.6359.

\section{Description}

Five specimens are selected for description and illustration:

Holotype MB.C.22170: laterally deformed, incomplete specimen with $65 \mathrm{~mm}$ conch diameter in haematitic ironstone; the last volution belongs almost completely to the body chamber (Fig. 20A).

Paratype SMF.Mbg.6359: laterally strongly deformed specimen with $94 \mathrm{~mm}$ conch diameter in haematitic ironstone; the last volution belongs almost completely to the body chamber (Fig. 21).

Paratype MB.C.22162: incomplete, weakly deformed specimen with total $75 \mathrm{~mm}$ diameter in haematitic, micritic limestone; conch dimensions can be obtained at $54 \mathrm{~mm}$ diameter (Fig. 20B).

Paratype MB.C.22163: strongly deformed, moderately preserved specimen with $74 \mathrm{~mm}$ conch diameter in ironstone (Fig. 20C).

Paratype MB.C.3654: slightly deformed, well-preserved steinkern specimen with $32 \mathrm{~mm}$ conch diameter filled with sparry calcite. Nearly the entire last volution belongs to the body chamber (Fig. 20D).

Holotype MB.C.22170 and paratype MB.C.22162 are, at 65 and $54 \mathrm{~mm}$ conch diameter, similar in their proportions and represent the adult stage of the species (Fig. 20A-B). In this stage, the conch is discoidal and subinvolute with moderate coiling rate; the whorl profile rounded triangular with steep umbilical wall, rounded umbilical margin and strongly converging flanks. The evenly rounded venter is separated from the flanks by two shallow spiral grooves. Both specimens possess ornament with lamellar, biconvex growth lines.

The smaller paratype MB.C.3654 with $32 \mathrm{~mm}$ conch diameter (Fig. 20D) is attributed to this species because it shows a conch geometry that is present in the earlier whorls of the two larger individuals. The conch is thinly pachyconic and subevolute; the whorl profile is depressed with rather steep umbilical wall and broadly rounded flanks and venter. Two very shallow spiral grooves are visible on the ventrolateral shoulder on both sides. Only some shell remains are preserved, they indicate coarse biconvex growth lines with a very high and narrow ventrolateral projection, which has a position at the spiral grooves. The suture line has, at a conch diameter of about $22 \mathrm{~mm}$, a very wide external lobe with subparallel flanks and two V-shaped lobes on the flank, of which the outer (lateral lobe) has the size of the prongs of the external lobe, and the inner one $\left(\mathrm{U}_{2}\right.$ lobe) is small (Fig. 22A), the $\mathrm{U}_{4}$ lobe is shallow and wide.

The large paratype SMF.Mbg.6359 with $94 \mathrm{~mm}$ diameter shows that the conch proportions change towards a more slender conch geometry with a narrower venter. The specimen shows that the longitudinal grooves are still present in this stage (Fig. 21).

\section{Remarks}

Among the species from the Red Ironstone, Pharciceras kayseri is most similar but differs in the slenderer conch (ww/dm $\sim 0.30$; ww/wh $\sim 0.65$ ) from P. kruegeri sp. nov. (ww/dm $\sim 0.40 ; \mathrm{ww} / \mathrm{wh}$ $\sim 1.05$ ) at $60 \mathrm{~mm}$ diameter. The ornament consists of very delicate growth lines in P. kayseri but coarse growth lines in P. kruegeri sp. nov.

The wide conch with the rounded-triangular whorl profile makes it rather easy to separate $P$. kruegeri sp. nov. from the other species of Pharciceras. 
Table. 10. Conch dimensions and ratios of selected specimens of Pharciceras kruegeri sp. nov.

\begin{tabular}{ccccccccccc}
\hline Specimen & dm & ww & wh & uw & ah & ww/dm & ww/wh & uw/dm & WER & IZR \\
\hline SMF.Mbg.6359 & 94.1 & 30.9 & 39.4 & 24.8 & 22.8 & 0.33 & 0.78 & 0.26 & 1.74 & 0.42 \\
MB.C.22170 & 64.7 & 26.9 & 26.7 & 17.9 & 15.9 & 0.42 & 1.01 & 0.28 & 1.76 & 0.40 \\
MB.C.22163 & 55.4 & 25.2 & 25.4 & 14.5 & - & 0.45 & 0.99 & 0.26 & - & - \\
MB.C.22162 & 54.0 & 24.8 & 23.0 & 15.6 & 13.5 & 0.46 & 1.08 & 0.29 & 1.78 & 0.41 \\
MB.C.3654 & 32.4 & 19.7 & 13.1 & 10.9 & 7.9 & 0.61 & 1.50 & 0.34 & 1.75 & 0.40 \\
\hline
\end{tabular}

Table 11. Conch ontogeny of Pharciceras kruegeri sp. nov.

\begin{tabular}{|c|c|c|c|}
\hline dm & conch shape & whorl cross section shape & whorl expansion \\
\hline $30 \mathrm{~mm}$ & $\begin{array}{l}\text { thinly pachyconic; subevolute } \\
\text { (ww/dm } \sim 0.62 ; \mathrm{uw} / \mathrm{dm} \sim 0.35 \text { ) }\end{array}$ & $\begin{array}{l}\text { moderately depressed; strongly embracing } \\
\quad(\mathrm{ww} / \mathrm{wh} \sim 1.55 ; \mathrm{IZR} \sim 0.40)\end{array}$ & $\begin{array}{c}\text { moderate } \\
(\mathrm{WER} \sim 1.75)\end{array}$ \\
\hline $50 \mathrm{~mm}$ & $\begin{array}{l}\text { thinly discoidal; subinvolute } \\
\text { (ww/dm } \sim 0.45 ; \mathrm{uw} / \mathrm{dm} \sim 0.28)\end{array}$ & $\begin{array}{l}\text { weakly depressed; strongly embracing } \\
\quad(\mathrm{ww} / \mathrm{wh} \sim 1.05 ; \mathrm{IZR} \sim 0.40)\end{array}$ & $\begin{array}{c}\text { moderate } \\
(\mathrm{WER} \sim 1.80)\end{array}$ \\
\hline $75 \mathrm{~mm}$ & $\begin{array}{l}\text { thinly discoidal; subinvolute } \\
\text { (ww/dm } \sim 0.38 ; \mathrm{uw} / \mathrm{dm} \sim 0.28)\end{array}$ & $\begin{array}{l}\text { weakly compressed; strongly embracing } \\
\quad \text { (ww/wh } \sim 0.90 ; \text { IZR } \sim 0.40 \text { ) }\end{array}$ & $\begin{array}{c}\text { moderate } \\
(\mathrm{WER} \sim 1.80)\end{array}$ \\
\hline
\end{tabular}

Pharciceras ferrum sp. nov. urn:1sid:zoobank.org:act:EE697AD8-5DEF-46FB-A9E0-FBA03C1EC485

Figs 23-24; Tables 12-13

\section{Diagnosis}

Pharciceras with thinly discoidal, subevolute conch at $30 \mathrm{~mm} \mathrm{dm}$ (ww/dm $\sim 0.42 ; \mathrm{uw} / \mathrm{dm} \sim 0.32$ ); extremely discoidal, subevolute at $60 \mathrm{~mm} \mathrm{dm}(\mathrm{ww} / \mathrm{dm} \sim 0.32 ; \mathrm{uw} / \mathrm{dm} \sim 0.32)$. Whorl profile nearly circular at $30 \mathrm{~mm} \mathrm{dm}(\mathrm{ww} / \mathrm{wh} \sim 1.05)$; weakly compressed at $60 \mathrm{~mm} \mathrm{dm}$ (ww/wh $\sim 0.75$ ); whorl expansion rate low to moderate. Venter continuously rounded throughout ontogeny. Adult stage with broadly convex, converging flanks continuing to the narrowly rounded venter. Growth lines coarse, strongly biconvex; ventrolateral shoulder with two spiral grooves. Outer suture line with symmetric, $\mathrm{U}$-shaped, blunt prongs of the external lobe, a V-shaped lateral lobe and a shallow and wide $\mathrm{U}_{2}$ lobe.

\section{Etymology}

Named after the Latin 'ferrum', meaning 'iron', after the occurrence of the specimen in iron ore.

\section{Material examined}

\section{Holotype}

GERMANY • Rhenish Mountains, Oberscheld (Eiserne Hand, Grube Friedrich); late Givetian (Red Ironstone); MB.C.30238. (Fig. 23A)

\section{Paratypes}

GERMANY • 2 specimens; Rhenish Mountains, Oberscheld (Westfeld der Grube Königszug, Firste der 120-150 m Sohle); late Givetian (Red Ironstone); Ahlburg Coll.; MB.C.3619, MB.C.3623 • 1 specimen; Rhenish Mountains, Oberscheld (Grube Stillingseisenzug, $30 \mathrm{~m}$ Sohle); late Givetian (Red Ironstone); Euel 1902 Coll.; MB.C.3646 • 2 specimens; Rhenish Mountains, Oberscheld; late Givetian (Red Ironstone); Lotz Coll.; MB.C.22165, MB.C.22166 1 specimen; Rhenish Mountains, Oberscheld (Grube Königszug, 120 m Sohle); late Givetian (Red Ironstone); MB.C.22192 • 1 specimen; Rhenish Mountains, 
Oberscheld (Grube Königszug); late Givetian (Red Ironstone); Etzold 1910 Coll.; MB.C.30237 • 1 specimen; Rhenish Mountains, Oberscheld (Grube Königszug, 90 m Sohle, Westflügel); late Givetian (Red Ironstone); Lotz 1902 Coll.; MB.C.30239 • 1 specimen; Rhenish Mountains, Oberscheld (Grube Prinzkessel, 100 m Sohle, Westflügel); late Givetian (Red Ironstone); Lotz 1901 Coll.; MB.C.30240.

\section{Description}

Six specimens are selected for description and illustration:

Holotype MB.C.30238: laterally deformed steinkern specimen with $78 \mathrm{~mm}$ conch diameter at the contact between a basaltic volcanic rock and a haematite ore (Fig. 23A).
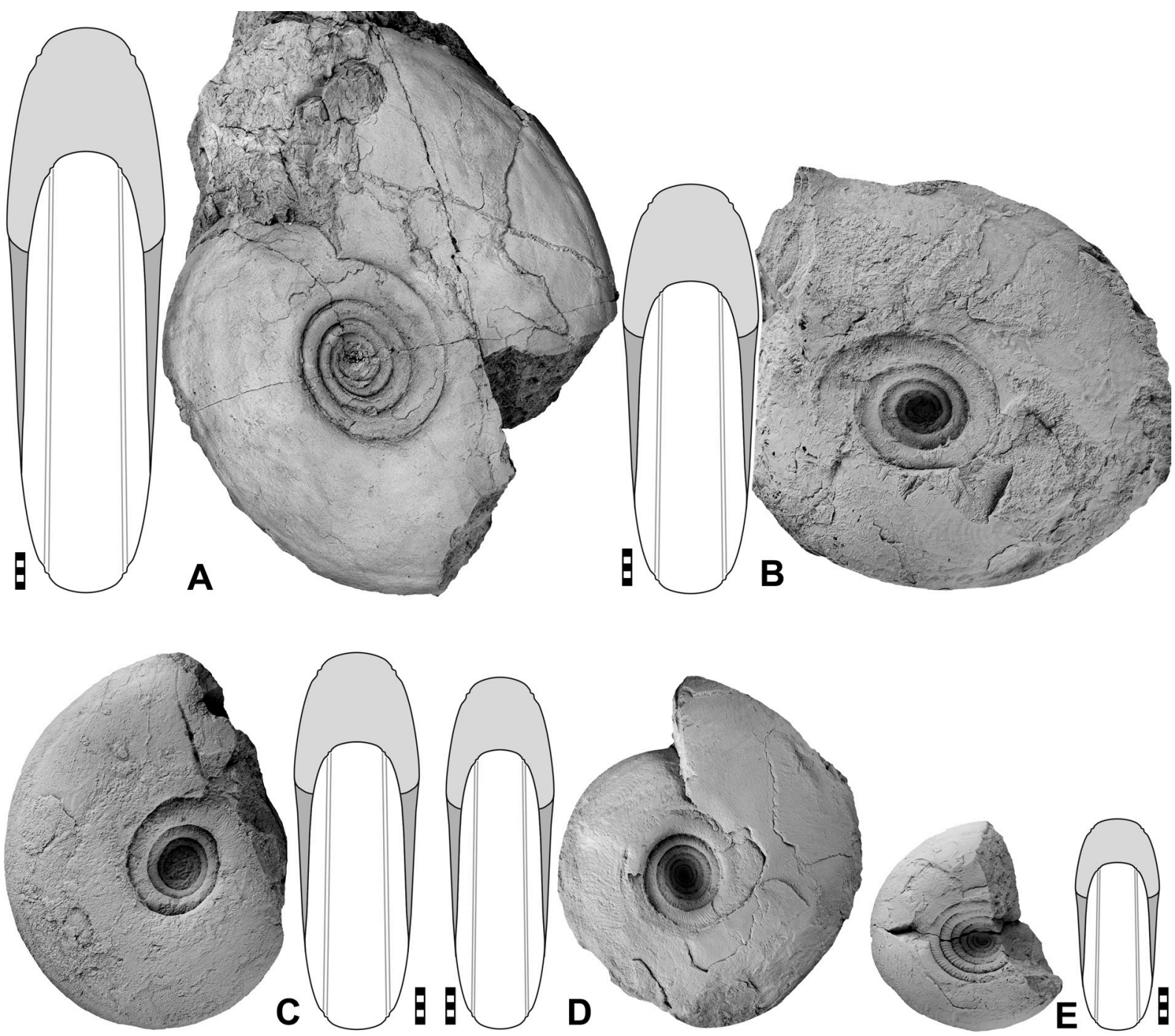

Fig. 23. Pharciceras ferrum sp. nov. A. Holotype MB.C.30238 from Oberscheld (Friedrich Mine). B. Paratype MB.C.3619 (Ahlburg Coll.) from Oberscheld (Königszug Mine). C. Paratype MB.C.22165 (Lotz Coll.) from Oberscheld. D. Paratype MB.C.30239 (Lotz 1902 Coll.) from Oberscheld (Königszug Mine). E. Paratype MB.C.3646 (Euel 1902 Coll.) from Oberscheld (Stillingseisenzug Mine). Scale bar units $=1 \mathrm{~mm}$. 
Paratype MB.C.3619: incomplete specimen with $59 \mathrm{~mm}$ conch diameter in iron-rich micritic limestone (Fig. 23B).

Paratype MB.C.22165: incomplete, laterally deformed specimen with $50 \mathrm{~mm}$ conch diameter in haematite ore. Parts of the suture line are visible (Fig. 23C).

Paratype MB.C.30239: incomplete, partly crushed specimen with $47 \mathrm{~mm}$ conch diameter in iron-rich limestone (Fig. 23D).

Paratype MB.C.3646: incomplete specimen with $29 \mathrm{~mm}$ conch diameter in ironstone (Fig. 23E).

Paratype MB.C.30237: sectioned specimen with $76 \mathrm{~mm}$ conch diameter in iron-rich limestone.

The material allows the description of conch geometry from 29 to $78 \mathrm{~mm}$ diameter. During this interval, the $\mathrm{ww} / \mathrm{dm}$ ratio decreases continuously from 0.45 to 0.30 , while the umbilical width ratio is stable at $0.30-0.35$. The coiling rate is also rather stable between 1.62 and 1.78. Holotype MB.C.30238 has, at $75 \mathrm{~mm}$ diameter, a compressed whorl profile with very shallow umbilical wall, convergent flanks and a narrowly rounded venter (Fig. 23A). A pair of faint spiral grooves is present in the ventrolateral area. Shell ornament is preserved in some specimens; it possesses coarse biconvex growth lines, which have an appearance of faint riblets in the inner whorls visible in the umbilicus of some specimens.

Paratype MB.C.3646 shows the suture line of the preadult stage (Fig. 24A); at a phragmocone diameter of $24 \mathrm{~mm}$, it shows a parallel-sided external lobe with lanceolate, blunt prongs. The lateral lobe is $\mathrm{V}$-shaped with weakly convex flanks and the $\mathrm{U}_{2}$ lobe is small and rounded.

\section{Remarks}

Pharciceras ferrum sp. nov. has some similarity to P. oberscheldense, but differs in the shape of the lateral lobe (V-shaped in P. ferrum sp. nov.but rounded in P. oberscheldense) and in the narrower whorl profile with a weakly flattened venter.
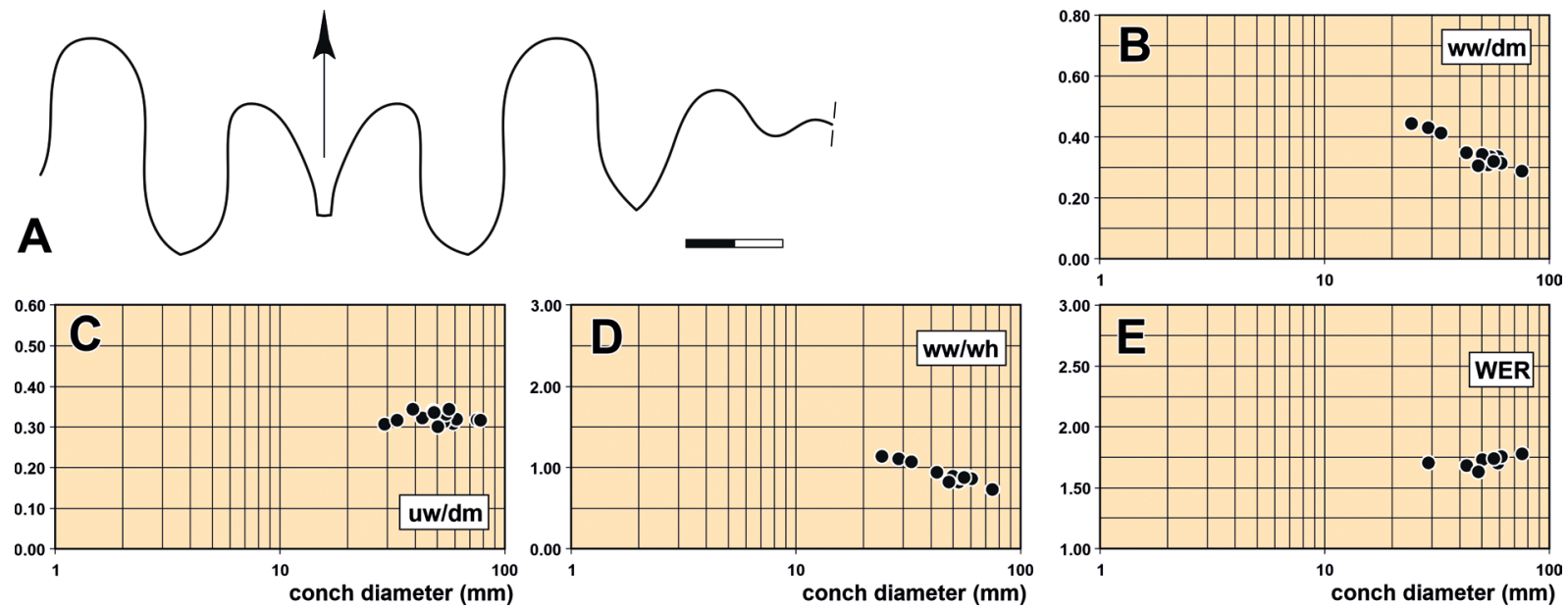

Fig. 24. Pharciceras ferrum sp. nov. A. Suture line of paratype MB.C.3646 (Euel 1902 Coll.) from Oberscheld (Stillingseisenzug Mine), at $\mathrm{dm}=24 \mathrm{~mm}$, ww $=12.0 \mathrm{~mm}$, wh $=8.5 \mathrm{~mm}$. B-E. Ontogeneric trajectories of the cardinal conch parameters. Abbreviations: see Material and methods. Scale bar units = $1 \mathrm{~mm}$. 
KORN D. \& BOCKWINKEL J., Ammonoids from the Roteisenstein Formation

Table 12. Conch dimensions and ratios of selected specimens of Pharciceras ferrum sp. nov.

\begin{tabular}{ccccccccccc}
\hline Specimen & dm & ww & wh & uw & ah & ww/dm & ww/wh & uw/dm & WER & IZR \\
\hline MB.C.3623 & 61.1 & 19.2 & 22.7 & 19.5 & 15.0 & 0.31 & 0.85 & 0.32 & 1.76 & 0.34 \\
MB.C.3619 & 59.0 & 19.8 & 22.8 & 18.2 & 13.8 & 0.34 & 0.87 & 0.31 & 1.70 & 0.39 \\
MB.C.22165 & 50.4 & 17.3 & 19.7 & 15.2 & 12.1 & 0.34 & 0.88 & 0.30 & 1.73 & 0.39 \\
MB.C.30239 & 48.4 & 14.8 & 18.4 & 16.3 & 10.5 & 0.31 & 0.81 & 0.34 & 1.63 & 0.43 \\
MB.C.3646 & 29.0 & 12.5 & 11.4 & 8.9 & 6.8 & 0.43 & 1.10 & 0.31 & 1.71 & 0.40 \\
MB.C.30237 & 75.49 & 21.73 & 30.52 & 23.98 & 18.91 & 0.29 & 0.71 & 0.32 & 1.78 & 0.38 \\
MB.C.30237 & 42.88 & 14.97 & 16.14 & 13.82 & 9.83 & 0.35 & 0.93 & 0.32 & 1.68 & 0.39 \\
\hline
\end{tabular}

Table 13. Conch ontogeny of Pharciceras ferrum sp. nov.

\begin{tabular}{cccc}
\hline $\mathbf{d m}$ & conch shape & whorl cross section shape & whorl expansion \\
\hline \multirow{2}{*}{$30 \mathrm{~mm}$} & $\begin{array}{c}\text { thinly discoidal; subevolute } \\
(\text { ww } / \mathrm{dm} \sim 0.42 ; \text { uw } / \mathrm{dm} \sim 0.32)\end{array}$ & $\begin{array}{c}\text { weakly depressed; strongly embracing } \\
(\text { ww } / \text { wh } \sim 1.05 ; \text { IZR } \sim 0.35)\end{array}$ & $\begin{array}{c}\text { low } \\
(\text { WER } \sim 1.70)\end{array}$ \\
\hline \multirow{2}{*}{$50 \mathrm{~mm}$} & $\begin{array}{c}\text { extremely discoidal; subevolute } \\
(\text { ww } / \mathrm{dm} \sim 0.33 ; \text { uw } / \mathrm{dm} \sim 0.32)\end{array}$ & $\begin{array}{c}\text { weakly compressed; strongly embracing } \\
(\text { ww } / \text { wh } \sim 0.80 ; \text { IZR } \sim 0.35)\end{array}$ & moderate \\
\hline \multirow{2}{*}{$75 \mathrm{~mm}$} & $\begin{array}{l}\text { extremely discoidal; subevolute } \\
(\text { ww } / \mathrm{dm} \sim 0.30 ; \text { uw } / \mathrm{dm} \sim 0.32)\end{array}$ & $\begin{array}{c}\text { weakly compressed; strongly embracing } \\
(\text { ww } / \text { wh } \sim 0.70 ; \text { IZR } \sim 0.35)\end{array}$ & moderate \\
\hline
\end{tabular}

Pharciceras galeatum Wedekind, 1918

Figs 25-27; Table 14

Pharciceras galeatum Wedekind, 1918: 128, 168, pl. 20 fig.1, text-fig. 37 b.

Pharciceras galeatum - Matern 1931: 92. — House in House \& Ziegler 1977: 79, pl. 5 figs 29-31.

\section{Diagnosis}

Pharciceras with extremely discoidal, subevolute conch at $80 \mathrm{~mm} \mathrm{dm}$ (ww/ dm $\sim 0.27$; uw/ $\mathrm{dm} \sim 0.35$ ). Whorl profile weakly compressed at $80 \mathrm{~mm} \mathrm{dm} \mathrm{(ww/wh} \sim 0.65$ ); whorl expansion moderate (WER 1.95). Venter narrowly rounded in the preadult stage; adult stage with strongly converging flanks bordered by a subangular ventrolateral shoulder from the tectiform venter. Growth lines coarse, strongly biconvex; ventrolateral shoulder with two spiral grooves. Outer suture line with symmetric, V-shaped prongs of the external lobe, a V-shaped lateral lobe, and a small rounded $\mathrm{U}_{2}$ lobe.

\section{Material examined}

\section{Holotype}

GERMANY • Rhenish Mountains, Oberscheld (Grube Prinzkessel); late Givetian (Red Ironstone); Welsch 1913 Coll.; illustrated by Wedekind (1918: pl. 20 fig. 1) and House \& Ziegler (1977: pl. 5 figs 29-31); SMF.Mbg.2316. (Fig. 25)

\section{Additional material}

GERMANY • 1 specimen; Rhenish Mountains, Oberscheld (Grube Anna); late Givetian (Red Ironstone); Koch Coll.; MB.C.22182 - 1 specimen; Rhenish Mountains, Oberscheld (Grube Sahlgrund, zwischen 370- und 420 m Sohlen); late Givetian (Red Ironstone); Kegel 1927 Coll.; MB.C.22180. 


\section{Description}

Holotype SMF.Mbg.2316 is a rather well-preserved but incomplete specimen with $74 \mathrm{~mm}$ conch diameter in red ironstone (Fig. 25). It allows the study of the adult conch as well as portions of the inner whorls. Its last volution is extremely discoidal and subevolute. It is widest at the rounded umbilical margin, from where the flanks strongly converge towards the tectiform venter. This shape of the venter is developed only during the last half volution; the venter is still rounded at 180 degrees before the largest

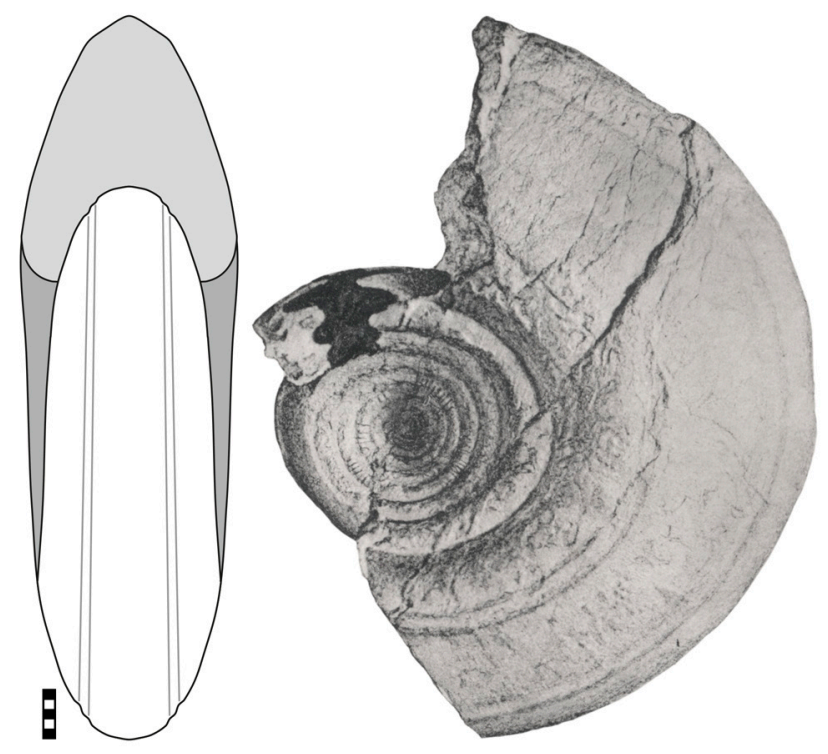

Fig. 25. Pharciceras galeatum Wedekind, 1918, specimen SMF.Mbg.2316 (Welsch 1913 Coll.) from Oberscheld (Prinzkessel Mine); reproduction from Wedekind (1918: pl. 20 fig. 1). Scale bar units = $1 \mathrm{~mm}$.

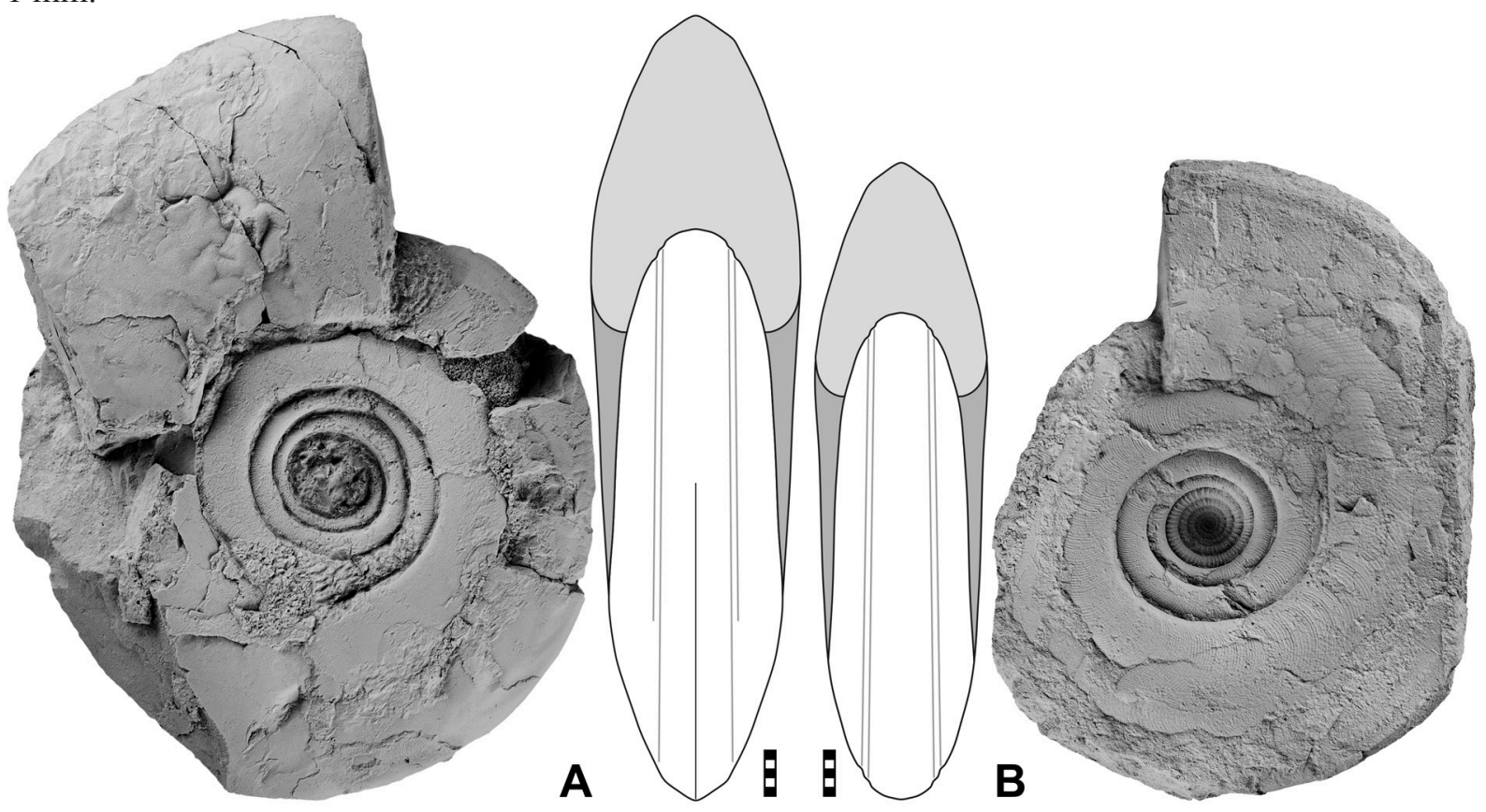

Fig. 26. Pharciceras galeatum Wedekind, 1918. A. Specimen MB.C.22182 (Koch Coll.) from Oberscheld (Anna Mine). B. Specimen MB.C.22180 (Kegel 1927 Coll.) from Oberscheld (Sahlgrund Mine). Scale bar units $=1 \mathrm{~mm}$. 
diameter. The ventrolateral shoulder bears two longitudinal grooves on each side. The inner whorls are very evolute and it appears that the whorl profile is crescent-shaped throughout most of the ontogeny.

The suture line of the holotype has a wide external lobe with a median saddle attaining more than half of the lobe depth (Fig. 27A). The prongs of the external lobe are V-shaped and symmetric. They are separated from the $\mathrm{V}$-shaped lateral lobe by a rather narrow, rounded ventrolateral saddle. The $\mathrm{U}_{2}$ lobe is rather small and rounded.

MB.C.22182 is an incomplete specimen with $88 \mathrm{~mm}$ conch diameter in red ironstone; the last volution belongs almost completely to the body chamber (Fig. 26A). It has an extremely discoidal and subevolute conch; the whorl profile is compressed with shallow umbilical wall, rounded umbilical margin, and convergent flanks that are widest at some distance from the umbilicus. The venter is narrowly rounded in the penultimate whorl, but developing into a subacute shape with a rounded keel at the end of the last volution. The inner whorls display coarse growth lines which become finer on the last volution. Runzelschicht is present in the dorsal whorl zone; it consists of fine wrinkles with slightly prorsiradiate direction.

MB.C.22180 is an incomplete specimen with $69 \mathrm{~mm}$ conch diameter in iron-rich micritic limestone, with several calcite veins cutting through (Fig. 26B). It shows very similar conch proportions; the whorl profile is also compressed with shallow umbilical wall, rounded umbilical margin, and convergent flanks. The narrowly rounded venter is separated from the flanks by a subangular margin accompanied by a shallow spiral groove. In the penultimate whorl, the venter develops into a subacute shape with a rounded keel at the end of the last volution. The inner whorls show a rather well-preserved ornament; the growth lines are coarse in the inner whorls and slightly finer on the last volution.

\section{Remarks}

Pharciceras galeatum is, in the adult stage, easily separable from all other pharciceratids by its tectiform venter. A clear separation using conch characters in small specimens may be difficult, but the compressed whorl profile and the rather narrow venter may serve as good criteria. The suture line provides another character for a separation, as $P$. galeatum possesses V-shaped ventrolateral prongs and a V-shaped lateral lobe.
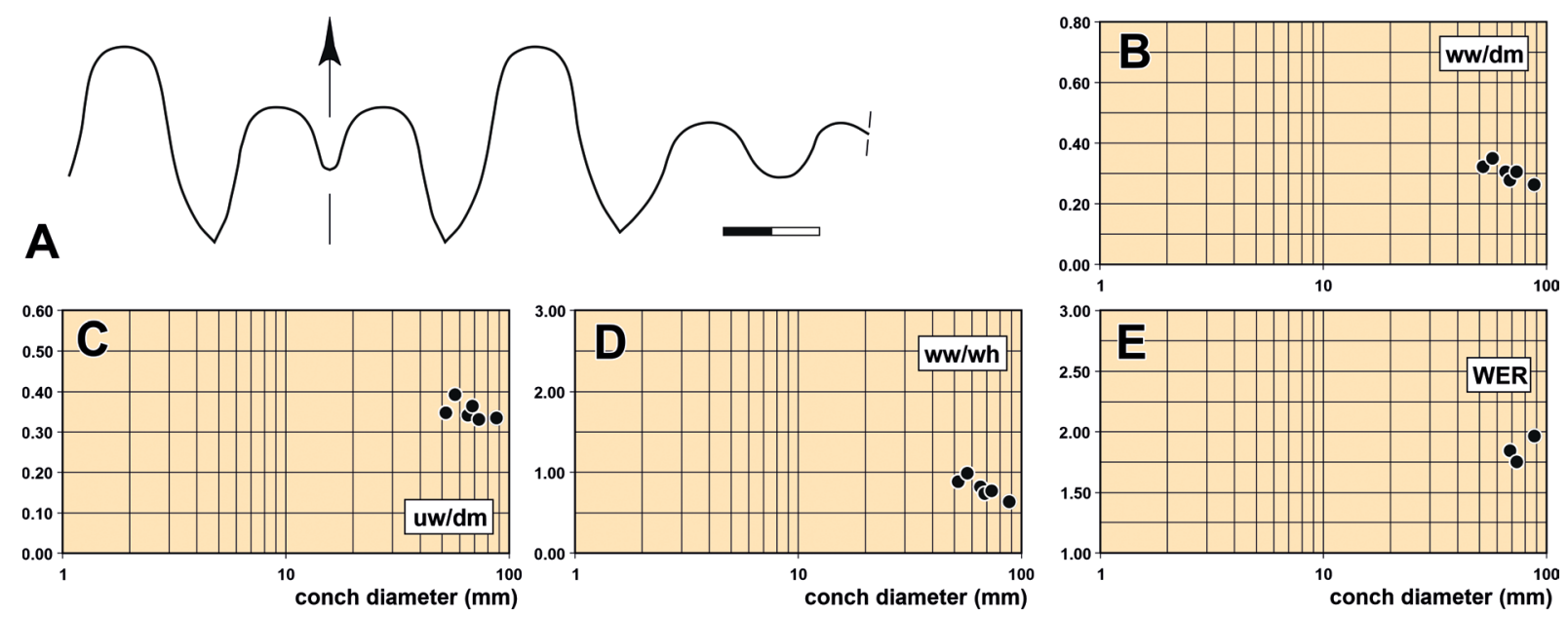

Fig. 27. Pharciceras galeatum Wedekind, 1918. A. Suture line of holotype SMF.Mbg.2316 (Welsch 1913 Coll.) from Oberscheld (Prinzkessel Mine), at ww $=15.0 \mathrm{~mm}$, wh $=9.0 \mathrm{~mm}$. B-E. Ontogeneric trajectories of the cardinal conch parameters. Abbreviations: see Material and methods. Scale bar units $=1 \mathrm{~mm}$. 
Table 14. Conch dimensions and ratios of the three available specimens of Pharciceras galeatum Wedekind, 1918.

\begin{tabular}{ccccccccccc}
\hline Specimen & dm & ww & wh & uw & ah & ww/dm & ww/wh & uw/dm & WER & IZR \\
\hline MB.C.22182 & 88.2 & 23.2 & 36.4 & 29.5 & 25.3 & 0.26 & 0.64 & 0.33 & 1.97 & 0.30 \\
SMF.Mbg.2315 & 73.5 & 22.5 & 29.0 & 24.3 & 18.0 & 0.31 & 0.78 & 0.33 & 1.75 & 0.38 \\
MB.C.22180 & 68.6 & 19.1 & 25.7 & 25.0 & 18.1 & 0.28 & 0.74 & 0.36 & 1.85 & 0.30 \\
\hline
\end{tabular}

Pharciceras galeatum has some similarity to Oxypharciceras chebbiense Bockwinkel, Becker \& Aboussalam, 2017, but differs in the shape of the venter, which is distinctively oxyconic from ca $60 \mathrm{~mm}$ $\mathrm{dm}$ in $O$. chebbiense but tectiform in P. galeatum.

\section{Genus Evopharciceras gen. nov. urn:1sid:zoobank.org:act:60AADDAB-845B-44EB-A858-DBB8FD5EA16A}

\section{Type species}

Evopharciceras formosum gen. et sp. nov.

\section{Diagnosis}

Pharciceratinae with evolute juvenile and adult stage, whorl profile moderately to strongly depressed. Adult stage with weakly depressed whorl profile; venter rounded. WER low or moderate. Juvenile stage sometimes finely ribbed, adult stage with weak to strong, single or paired ventrolateral grooves. Suture line with wide external lobe, short $\mathrm{E}_{1}$ lobe, high median saddle, deep lanceolate $\mathrm{E}_{2}$ lobe, large, deep lanceolate lateral lobe, two outer and two inner umbilical lobes. Suture line formula $\left(E_{2} E_{1} E_{2}\right) L U_{2} U_{4}$ : $\mathrm{U}_{3} \mathrm{U}_{1} \mathrm{I}$.

\section{Included species}

Evopharciceras formosum gen. et sp. nov., Rhenish Mountains; Pharciceras evolvens Bockwinkel, Becker \& Ebbighausen, 2009, Anti-Atlas.

\section{Remarks}

The new genus differs from Pharciceras first in the conch geometry with a high umbilicus/diameter ratio in all stages, which in Pharciceras decreases in the course of ontogeny. Second, the two genera are distinguished in the form of the external lobe: in Pharciceras the median saddle is low and usually does not reach half the height of the external lobe; in Evopharciceras gen. nov., however, the median saddle is very high and reaches more than three-quarters the height of the external lobe.

Evopharciceras formosum gen. et sp. nov. urn:1sid:zoobank.org:act:F58EF052-3ED6-4798-81FC-D782A0CC08BF

Figs 28-29; Tables 15-16

\section{Diagnosis}

Evopharciceras gen. nov. with thinly discoidal, evolute conch at $35 \mathrm{~mm} \mathrm{dm} \mathrm{(ww/dm} \sim 0.35 ; \mathrm{uw} / \mathrm{dm}$ $\sim 0.50$ ) and extremely discoidal, evolute conch at $65 \mathrm{~mm} \mathrm{dm} \mathrm{(ww/dm} \sim 0.30$; uw/ $\mathrm{dm} \sim 0.50$ ). Whorl profile weakly depressed with convergent flanks and broadly rounded venter, umbilical wall steep. Growth lines rather coarse, strongly biconvex; ventrolateral shoulder with two spiral grooves in the middle growth stage. Outer suture line with high median saddle, symmetric, lanceolate prongs of the external lobe, a lanceolate, weakly pouched lateral lobe, a very narrow, acute and small $\mathrm{U}_{2}$ lobe and a V-shaped $\mathrm{U}_{4}$ lobe. 


\section{Etymology}

Named after the Latin 'formosum', meaning 'beautiful', because of the decorated shell.

\section{Material examined}

\section{Holotype}

GERMANY • Rhenish Mountains, Oberscheld (Grube Beilstein); late Givetian (Red Ironstone); Lotz 1901-1902 Coll.; MB.C.30241. (Fig. 28A)

\section{Paratype}

GERMANY • 1 specimen; Rhenish Mountains, Oberscheld (Grube Anna); late Givetian (Red Ironstone); Koch Coll.; MB.C.22173.

\section{Description}

Paratype MB.C.22173: Laterally deformed, but otherwise well-preserved specimen with $35 \mathrm{~mm}$ conch diameter in iron-rich micritic limestone. Most of the specimen is covered with shell; a quarter of the last volution belongs to the body chamber (Fig. 28B). It has a discoidal and evolute conch with low coiling rate (Fig. 28B); the whorl profile is subcircular with shallow umbilical wall, broadly rounded flanks and a broadly rounded venter. One faint ventrolateral spiral groove on each side separates flanks and venter. The ornament includes lamellar growth lines, which extend with low dorsolateral projection on the umbilical margin, a shallow lateral sinus, a prominent, narrow ventrolateral projection and a deep ventral sinus.

The larger holotype MB.C.30241 is a laterally strongly deformed specimen with about $65 \mathrm{~mm}$ conch diameter in haematitic limestone, showing the suture line (Fig. 28A). It has a similar conch geometry, but is slightly slenderer. It displays the suture line, which has a rather narrow external lobe with high median saddle and narrow and slightly pouched, lanceolate prongs. The lateral lobe is also very narrow and lanceolate; the $U_{2}$ lobe is very narrow and the $U_{4}$ lobe is V-shaped and wider than the $U_{2}$ lobe (Fig. 29A).

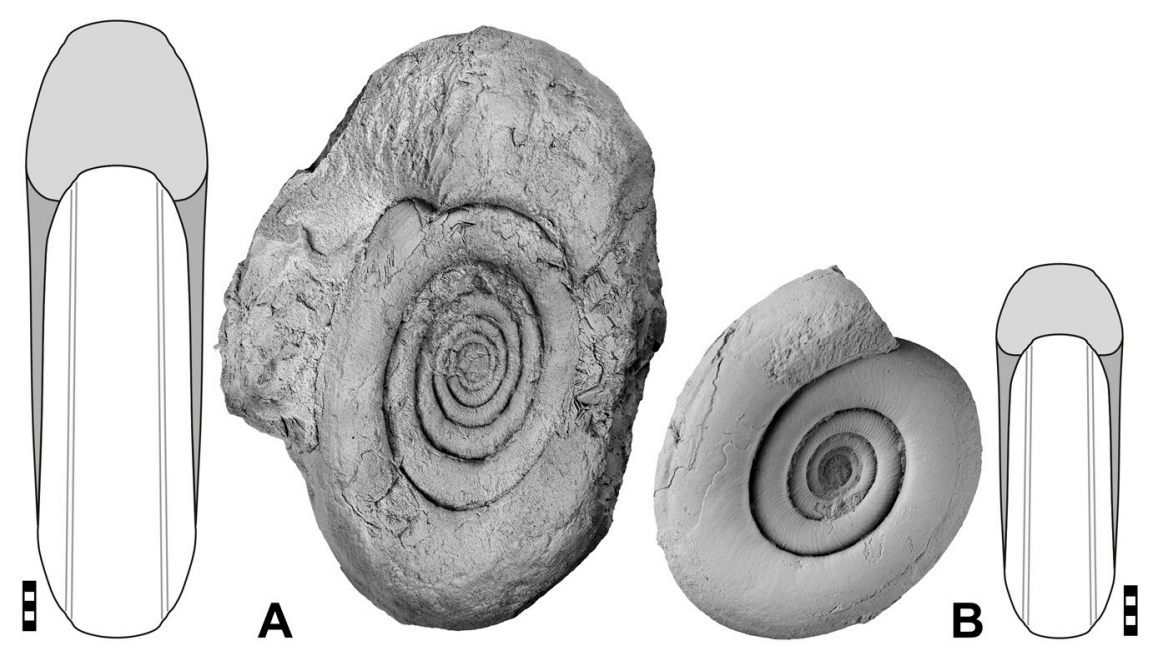

Fig. 28. Evopharciceras formosum gen. et sp. nov. A. Holotype MB.C.30241 (Lotz 1901-1902 Coll.) from Oberscheld (Beilstein Mine). B. Paratype MB.C.22173 (Koch Coll.) from Oberscheld (Anna Mine). Scale bar units $=1 \mathrm{~mm}$. 
Table 15. Conch dimensions and ratios of selected specimens of Evopharciceras formosum gen. et sp. nov.

\begin{tabular}{ccccccccccc}
\hline Specimen & dm & ww & wh & uw & ah & ww/dm & ww/wh & uw/dm & WER & IZR \\
\hline MB.C.30241 & 62.6 & 18.4 & 18.3 & 31.5 & 14.7 & 0.29 & 1.00 & 0.50 & 1.71 & 0.20 \\
MB.C.22173 & 35.8 & 12.4 & 10.3 & 18.0 & 7.3 & 0.35 & 1.20 & 0.50 & 1.58 & 0.29 \\
\hline
\end{tabular}

Table 16. Conch ontogeny of Evopharciceras formosum gen. et sp. nov.

\begin{tabular}{cccc}
\hline $\mathbf{d m}$ & conch shape & whorl cross section shape & whorl expansion \\
\hline \multirow{2}{*}{$35 \mathrm{~mm}$} & thinly discoidal; evolute & $\begin{array}{c}\text { weakly depressed; moderately embracing } \\
(\text { ww } / \mathrm{dm} \sim 0.35 ; \text { uw } / \mathrm{dm} \sim 0.50)\end{array}$ & (ww/wh $\sim 1.20 ;$ IZR $\sim 0.25)$ \\
\hline \multirow{2}{*}{$65 \mathrm{~mm}$} & $\begin{array}{c}\text { extremely discoidal; evolute } \\
(\mathrm{ww} / \mathrm{dm} \sim 0.30 ; \text { uw } / \mathrm{dm} \sim 0.50)\end{array}$ & $\begin{array}{c}\text { weakly depressed; moderately embracing } \\
(\text { ww } / \text { wh } \sim 1.00 ; \text { IZR } \sim 0.20)\end{array}$ & (WER $\sim 1.55)$ \\
\hline
\end{tabular}

\section{Remarks}

Evopharciceras formosum gen. et sp. nov. is similar to Extropharciceras metallicum sp. nov. but differs in the slightly stouter conch and the slightly narrower umbilicus. The suture line provides more specific criteria for the separation of the two species: while the $\mathrm{E}_{2}, \mathrm{~L}$ and $\mathrm{U}_{2}$ lobes are very narrow and lanceolate in Evopharciceras gen. nov., they are wider and tongue- or V-shaped in Extropharciceras.

Genus Extropharciceras Bockwinkel, Becker \& Ebbighausen, 2009

\section{Type species}

Extropharciceras conex Bockwinkel, Becker \& Ebbighausen, 2009 (original designation).
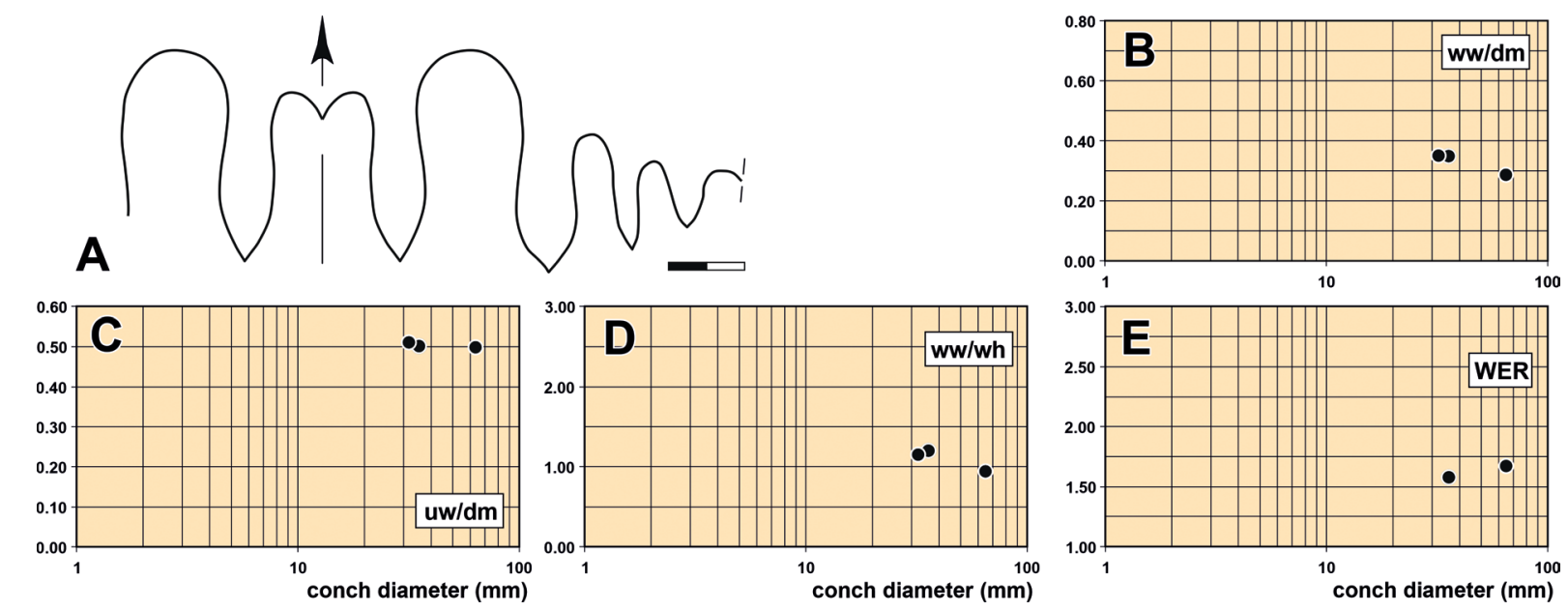

Fig. 29. Evopharciceras formosum gen. et sp. nov. A. Suture line of holotype MB.C.30241 (Lotz 19011902 Coll.) from Oberscheld (Beilstein Mine), at ww $=14.8 \mathrm{~mm}$, wh=14.2 mm. B-E. Ontogeneric trajectories of the cardinal conch parameters. Abbreviations: see Material and methods. Scale bar units = $1 \mathrm{~mm}$. 


\section{Diagnosis}

Pharciceratinae with discoidal to pachyconic, subevolute to evolute juvenile stage, whorl profile depressed. Adult stage subinvolute to subevolute with weakly depressed to weakly compressed whorl profile; venter rounded or tabulate. WER low or moderate. Juvenile stage sometimes finely ribbed, adult stage with weak to strong, single or paired ventrolateral grooves. Suture line with very wide external lobe, deep or shortened median $\mathrm{E}_{1}$ lobe, moderately high median saddle, deep, tongue-shaped $\mathrm{E}_{2}$ lobe, large, midflank lateral lobe, two or three outer and three inner umbilical lobes. Suture line formula $\left(E_{2}\right.$ $\left.\mathrm{E}_{1} \mathrm{E}_{2}\right) \mathrm{L} \mathrm{U}_{2} \mathrm{U}_{4}: \mathrm{U}_{5} \mathrm{U}_{3} \mathrm{U}_{1}$ I to $\left(\mathrm{E}_{2} \mathrm{E}_{1} \mathrm{E}_{2}\right) \mathrm{L} \mathrm{U}_{2} \mathrm{U}_{4} \mathrm{U}_{6}: \mathrm{U}_{5} \mathrm{U}_{3} \mathrm{U}_{1} \mathrm{I}$.

\section{Included species}

Extropharciceras conex Bockwinkel, Becker \& Ebbighausen, 2009, Anti-Atlas; Pharciceras arenicum Petter, 1959, Ougarta, Algeria; Ammonites Becheri von Buch, 1832, Rhenish Mountains; Pharciceras arenicum var. carinata Petter, 1959, Ougarta, Algeria; Extropharciceras librum Bockwinkel, Becker \& Ebbighausen, 2009, Anti-Atlas; Extropharciceras gentile Bockwinkel, Becker \& Ebbighausen, 2015, Anti-Atlas; Extropharciceras serum Bockwinkel, Becker \& Ebbighausen, 2015, Anti-Atlas; Extropharciceras worki Bockwinkel, Becker \& Aboussalam, 2017, Anti-Atlas; Extropharciceras metallicum sp. nov., Rhenish Mountains.

Extropharciceras metallicum sp. nov. urn:1sid:zoobank.org:act:9C27C6D3-6295-46F4-8397-D1FF2AB7C89A

Figs 30-31; Tables 17-18

\section{Diagnosis}

Extropharciceras with extremely discoidal, evolute conch at $60 \mathrm{~mm} \mathrm{dm}$ (ww/ $\mathrm{dm} \sim 0.25$; $\mathrm{uw} / \mathrm{dm} \sim 0.50$ ). Whorl profile weakly depressed or weakly compressed with convergent flanks and broadly rounded venter, umbilical wall steep. Growth lines rather coarse, strongly biconvex; ventrolateral shoulder with two spiral grooves in the middle growth stage. Outer suture line with lanceolate prongs of the external lobe, a tongue-shaped lateral lobe with acute base and V-shaped $\mathrm{U}_{2}$ and $\mathrm{U}_{4}$ lobes and a very small, rounded $\mathrm{U}_{6}$.

\section{Etymology}

Named after the Latin 'metallicum', because of the origin of the specimens from iron ore.

\section{Material examined}

Holotype

GERMANY • Rhenish Mountains, Oberscheld (Grube Prinzkessel, Liegendes Lager auf der $130 \mathrm{~m}$ Sohle); late Givetian (Red Ironstone); Stahl 1902 Coll.; MB.C.22151. (Fig. 30A)

\section{Paratypes}

GERMANY • 1 specimen; Rhenish Mountains, Oberscheld (Grube Prinzkessel, Liegendes Lager); late Givetian (Red Ironstone); Becker 1902 Coll.; MB.C.3610 • 1 specimen; Rhenish Mountains, Oberscheld (Grube Prinzkessel, 125 m Lager); late Givetian (Red Ironstone); Lotz Coll.; MB.C.30244 • 1 specimen; Rhenish Mountains, Oberscheld; late Givetian (Red Ironstone); MB.C.30242.

\section{Additional material}

GERMANY • 2 specimens; Rhenish Mountains, Oberscheld (Grube Prinzkessel, $60 \mathrm{~m}$ Sohle); late Givetian (Red Ironstone); Lotz 1902 Coll.; MB.C.3612, MB.C.30242 • 1 specimen; Rhenish Mountains, Oberscheld (Grube Prinzkessel, Hangendes Lager); late Givetian (Red Ironstone); Dresler 1906 


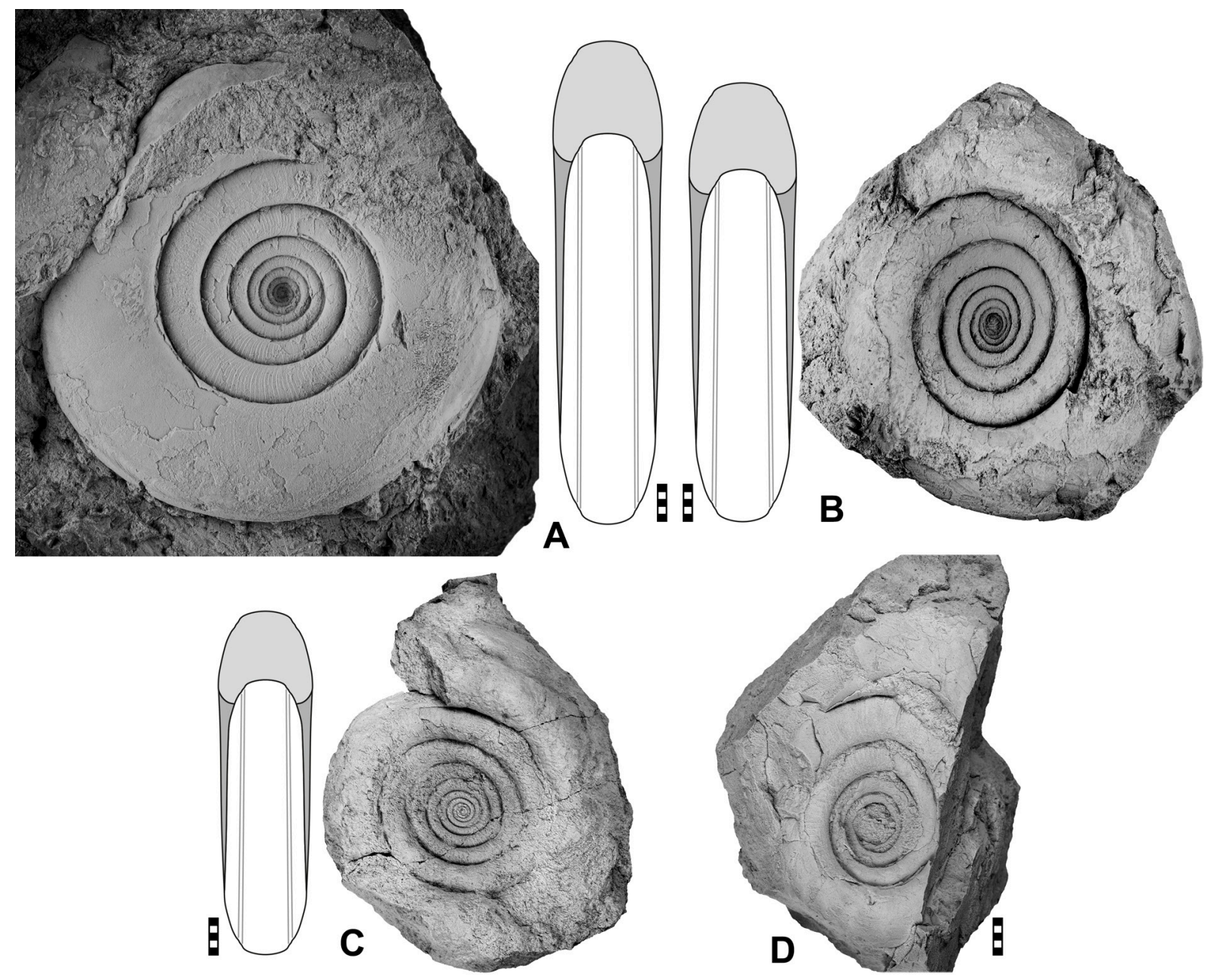

Fig. 30. Extropharciceras metallicum sp. nov. A. Holotype MB.C.22151 (Stahl 1902 Coll.) from Oberscheld (Prinzkessel Mine). B. Paratype MB.C.3610 (Becker 1902 Coll.) from Oberscheld (Prinzkessel Mine). C. Paratype MB.C.30244 (Lotz 1902 Coll.) from Oberscheld (Prinzkessel Mine). D. Paratype MB.C.30242 from Oberscheld. Scale bar units $=1 \mathrm{~mm}$.
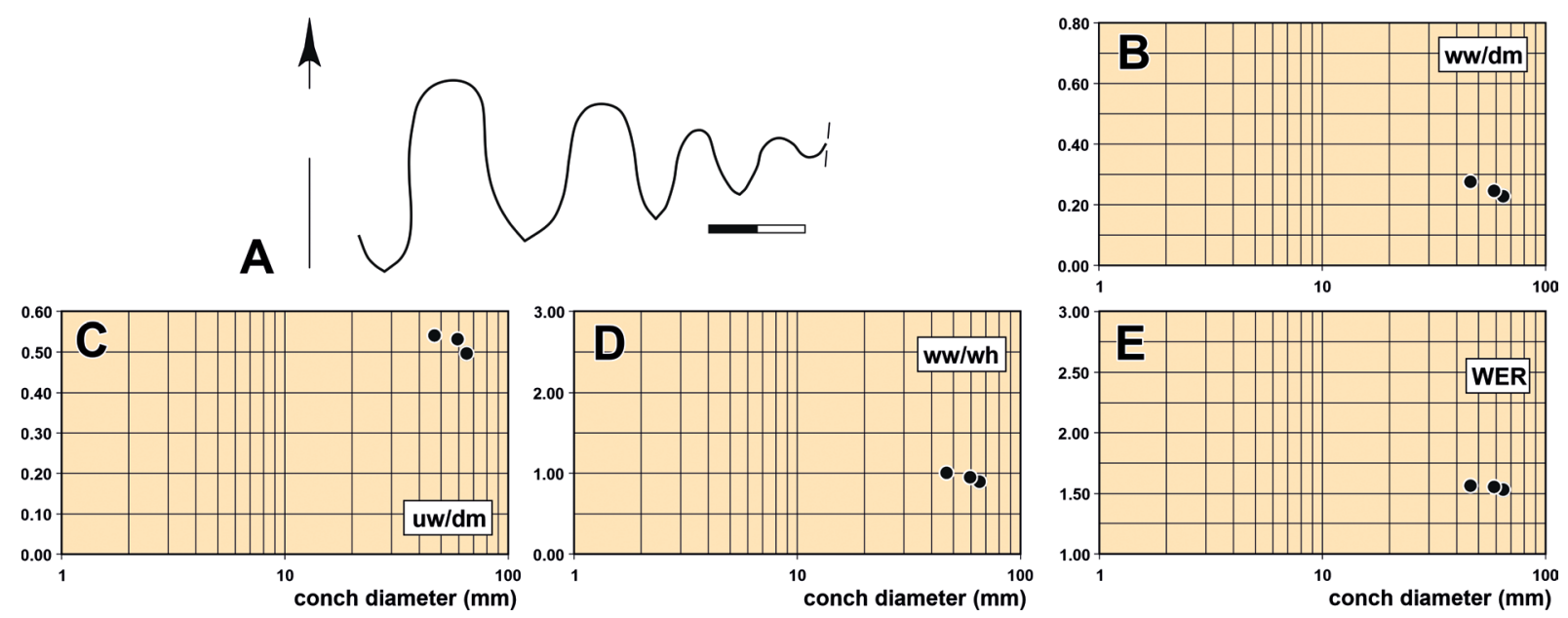

Fig. 31. Extropharciceras metallicum sp. nov. A. Suture line of paratype MB.C.30242 from Oberscheld, at $\mathrm{dm}=34.5 \mathrm{~mm}, \mathrm{wh}=8.5 \mathrm{~mm}$. B-E. Ontogeneric trajectories of the cardinal conch parameters. Scale bar units $=1 \mathrm{~mm}$. 
Table 17. Conch dimensions (partly estimated) and ratios of selected specimens of Extropharciceras metallicum sp. nov.

\begin{tabular}{ccccccccccc}
\hline Specimen & dm & ww & wh & uw & ah & ww/dm & ww/wh & uw/dm & WER & IZR \\
\hline MB.C. 22151 & 65.1 & 14.7 & 16.3 & 32.4 & 12.5 & 0.23 & 0.90 & 0.50 & 1.53 & 0.24 \\
MB.C. 3610 & 59.1 & 14.4 & 15.0 & 31.6 & 11.6 & 0.24 & 0.96 & 0.53 & 1.55 & 0.23 \\
MB.C.30244 & 46.3 & 12.7 & 12.5 & 25.1 & 9.2 & 0.27 & 1.02 & 0.54 & 1.56 & 0.26 \\
\hline
\end{tabular}

Table 18. Conch ontogeny of Extropharciceras metallicum sp. nov.

\begin{tabular}{cccc}
\hline $\mathbf{d m}$ & conch shape & whorl cross section shape & whorl expansion \\
\hline \multirow{2}{*}{$45 \mathrm{~mm}$} & $\begin{array}{c}\text { extremely discoidal; evolute } \\
(\text { ww } / \mathrm{dm} \sim 0.27 \text {; uw } / \mathrm{dm} \sim 0.55)\end{array}$ & $\begin{array}{c}\text { weakly depressed; moderately embracing } \\
\text { (ww/wh } \sim 1.05 ; \text { IZR } \sim 0.25)\end{array}$ & low \\
\hline \multirow{2}{*}{$65 \mathrm{~mm}$} & $\begin{array}{c}\text { extremely discoidal; evolute } \\
(\text { ww } / \mathrm{dm} \sim 0.23 ; \text { uw } / \mathrm{dm} \sim 0.50)\end{array}$ & $\begin{array}{c}\text { weakly compressed; moderately embracing } \\
(\text { ww } / \text { wh } \sim 0.90 ; \text { IZR } \sim 0.25)\end{array}$ & low \\
\hline
\end{tabular}

Coll.; MB.C.3643 - 3 specimens; Rhenish Mountains, Oberscheld (Staatliche Grube); late Givetian (Red Ironstone); Hubach 1920 Coll.; MB.C.4299, MB.C.4301, MB.C.4302 • 2 specimens; Rhenish Mountains, Weilburg (Grube Georg-Joseph); late Givetian (Red Ironstone); Kegel Coll.; MB.C.30245, MB.C.30246.

\section{Description}

Four specimens are selected for description and illustration:

Holotype MB.C.22151: rather well-preserved specimen with $61 \mathrm{~mm}$ conch diameter embedded in a block of haematite ore (Fig. 30A).

Paratype MB.C.3610: incomplete specimen with $59 \mathrm{~mm}$ conch diameter in haematite ore (Fig. 30B).

Paratype MB.C.30244: incomplete specimen with about $46 \mathrm{~mm}$ conch diameter in haematitic limestone (Fig. 30C).

Paratype MB.C.30242: incomplete specimen with about $50 \mathrm{~mm}$ conch diameter in haematite ore (Fig. 30D).

Holotype MB.C.22151 has an extremely discoidal and evolute conch (uw/dm=0.49); the whorl profile is compressed with oblique umbilical wall, rounded umbilical margin and slowly converging flanks and narrowly rounded venter (Fig 30A). Venter and flanks separated by a shallow spiral groove that is accompanied by delicate ridges. Lamellar biconvex growth lines are well-preserved on the specimen; they extend strongly biconvex on the flank to form a narrow and high ventrolateral projection. The ventral sinus is narrow and deep.

None of the specimens shows a complete outer suture line; in specimen MB.C.30242, for instance, the median saddle cannot be studied. The lateral prongs of the external lobe appears to be rather narrow and lanceolate. The lateral lobe is tongue-shaped but acute at its base; the $\mathrm{U}_{2}$ and $\mathrm{U}_{4}$ lobes are narrow and V-shaped, the $\mathrm{U}_{6}$ lobe is small and rounded (Fig. 31A). 


\section{Remarks}

Extropharciceras metallicum sp. nov. differs from Evopharciceras formosum gen. et sp. nov. in the slightly narrower, more evolute conch. The suture line differs in the shape of the lateral and $\mathrm{U}_{2}$ lobes, which are very narrow and lanceolate in Evopharciceras gen. nov., but wider and tongue- or V-shaped in Extropharciceras.

Extropharciceras becheri (von Buch, 1832)

Figs 32-34; Tables 19-20

Ammonites Becheri von Buch, 1832: 171, pl. 2 fig. 2.

Ammonites Becheri-Beyrich 1837a: 31, pl. 1 figs 7-8; 1884: 211.

Goniatites (Prolecanites) Becheri - Frech 1888: 28, pl. 2 fig. 4.

Prolecanites Becheri - Frech 1897: 177e, text-fig. 2e, pl. 35 fig. 11; 1902: 64, pl. 3 fig. 13, text-fig. 21e. Pharciceras Becheri - Wedekind 1918: 127.

Pharciceras becheri - Matern 1931: 90.

Extropharciceras becheri-Bockwinkel et al. 2009: 95.

non Pharciceras becheri - Petter 1959: 137, pl. 7 fig. 5, text-fig. 33e. — Kullmann \& Ziegler 1970: 78, pl. 1 fig. 5 , text-figs $2 \mathrm{c}, 3 \mathrm{c}, 4$.

\section{Diagnosis}

Extropharciceras with thinly pachyconic, evolute conch at $20 \mathrm{~mm} \mathrm{dm}$ (ww/ dm $\sim 0.60$; uw/ $\mathrm{dm} \sim 0.45$ ), thickly discoidal, subevolute conch at $40 \mathrm{~mm} \mathrm{dm}(\mathrm{ww} / \mathrm{dm} \sim 0.50 ; \mathrm{uw} / \mathrm{dm} \sim 0.40$ ) and thinly discoidal, subevolute conch at $80 \mathrm{~mm} \mathrm{dm}(\mathrm{ww} / \mathrm{dm} \sim 0.35 ; \mathrm{uw} / \mathrm{dm} \sim 0.35)$. Whorl profile changing from strongly depressed in the juvenile stage ( $\mathrm{ww} / \mathrm{wh} \sim 2.30$ ) to weakly compressed in the adult stage (ww/wh $\sim 0.95$ ). Whorl profile crescent-shaped with continuously rounded venter up to $35 \mathrm{~mm} \mathrm{dm}$; adult stage with slightly flattened, convergent flanks bordered by a pronounced ventrolateral shoulder from the slightly flattened venter. Growth lines fine, strongly biconvex; ventrolateral shoulder with two spiral grooves in the middle growth stage. Outer suture line with symmetric, lanceolate prongs of the external lobe, a V-shaped lateral lobe and small, $\mathrm{V}$-shaped $\mathrm{U}_{2}, \mathrm{U}_{4}$ and $\mathrm{U}_{6}$ lobes.

\section{Material examined}

\section{Neotype}

GERMANY • Rhenish Mountains, Oberscheld (Grube Volpertseiche); late Givetian (Red Ironstone); Lotz 1901-1902 Coll.; MB.C.3609. (Fig. 32A)

\section{Additional material}

GERMANY • 1 specimen; Rhenish Mountains, Oberscheld (Grube Anna); late Givetian (Red Ironstone); Koch Coll.; MB.C.3613 • 1 specimen; Rhenish Mountains, Oberscheld; late Givetian (Red Ironstone); MB.C.30247 • 1 specimen; Rhenish Mountains, Oberscheld (Grube Prinzkessel, Liegendes Lager der 130 m Sohle); late Givetian (Red Ironstone); Lotz 1901-1902 Coll.; MB.C.30248.

\section{Remarks to the type material}

The original specimen described by von Buch (1832) was from the Goldfuß collection and could not be traced; it is missing in the Bonn collection and probably lost. Therefore, a neotype (MB.C. 3609) from the type area is proposed here. The selection of this neotype stabilises the use of the species name, which was mainly coined by Frech $(1888,1897-1902,1902)$. 
As the species description provided by von Buch (1832) can hardly be used for a definition of the species, we herein refer to the description by Beyrich (1837a, 1837b), which allows a characterisation of the species. As the original specimen figured by Beyrich could not be traced, we propose herein a neotype from the Volpertseiche Mine near Oberscheld.

[The original specimen of von Buch (1832) came from the Rinzenbach Mine near "Edbach" (or "Eybach"). This mine was located between Eibach and Oberscheld and was later included in the Königszug Mine.]
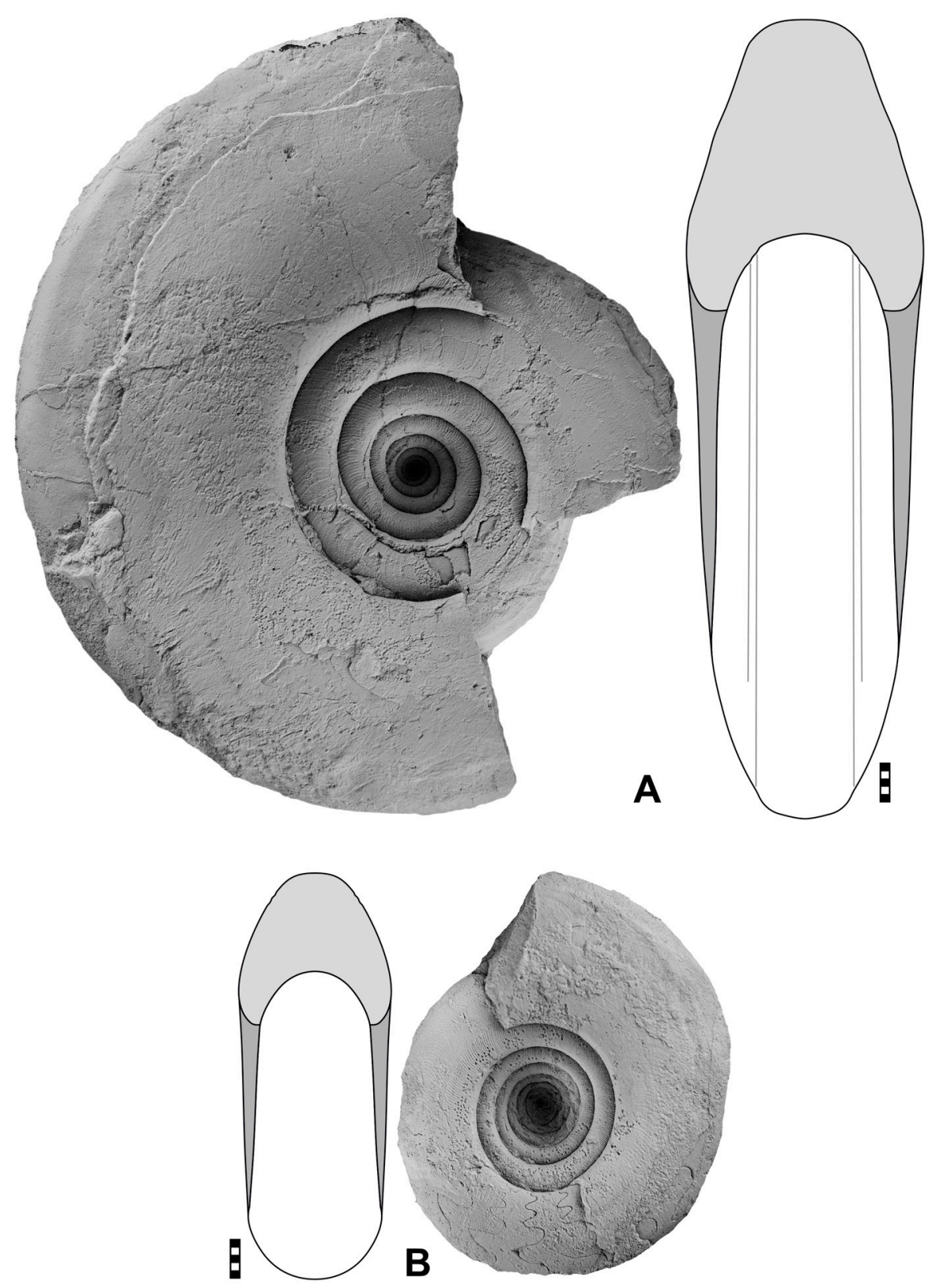

Fig. 32. Extropharciceras becheri (von Buch, 1832). A. Neotype MB.C.3609 (Lotz 1901-1902 Coll.) from Oberscheld (Volpertseiche Mine). B. Specimen MB.C.3613 (Koch Coll.) from Oberscheld (Anna Mine). Scale bar units $=1 \mathrm{~mm}$. 

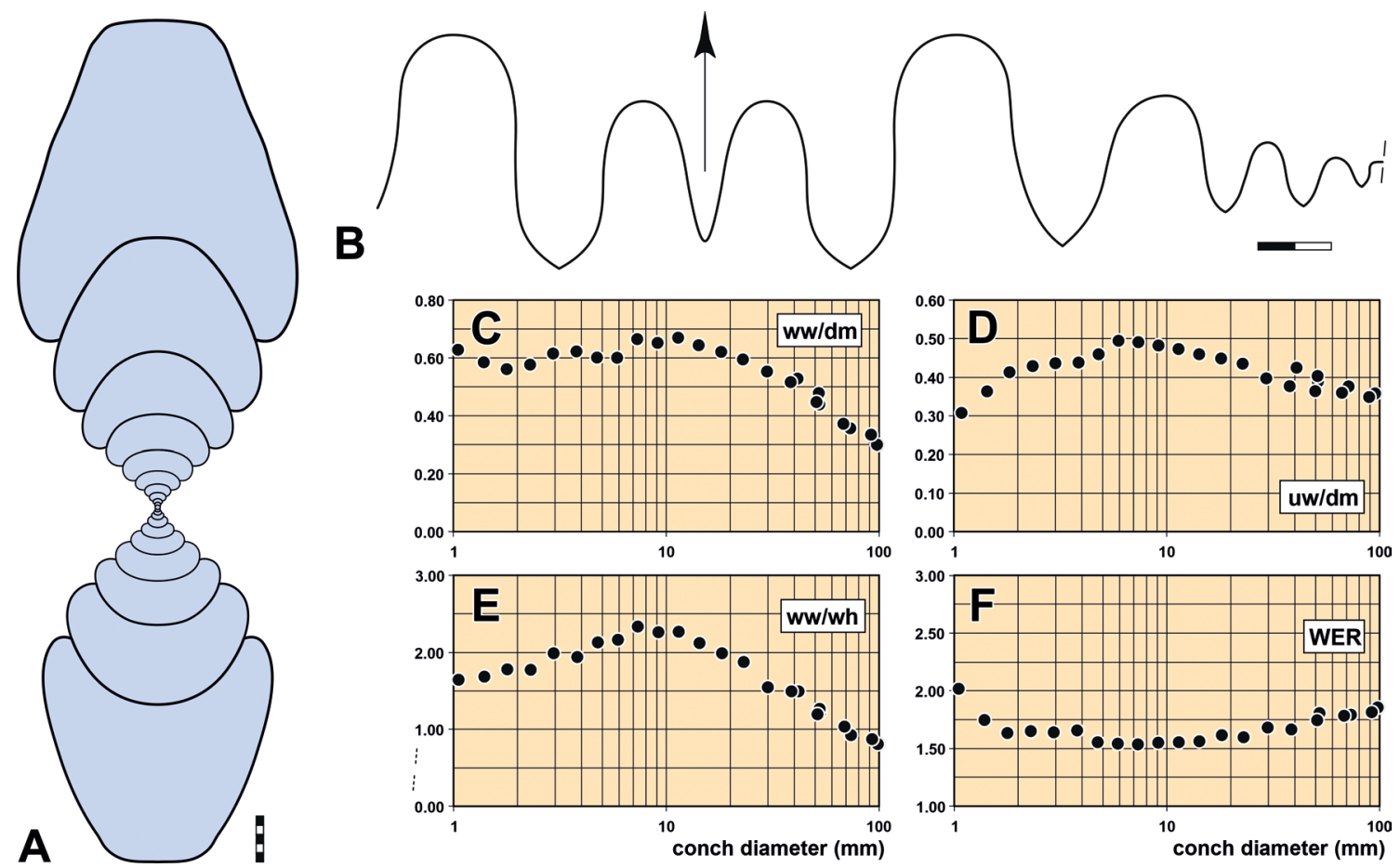

Fig. 33. Extropharciceras becheri (von Buch, 1832). A. Cross section of specimen MB.C.30247 from Oberscheld. B. Suture line of specimen MB.C.3613 (Koch Coll.) from Oberscheld (Anna Mine), at $\mathrm{dm}=40.0 \mathrm{~mm}, \mathrm{ww}=14.5 \mathrm{~mm}, \mathrm{wh}=12.5 \mathrm{~mm}$. C-F. Ontogeneric trajectories of the cardinal conch parameters. Abbreviations: see Material and methods. Scale bar units $=1 \mathrm{~mm}$.

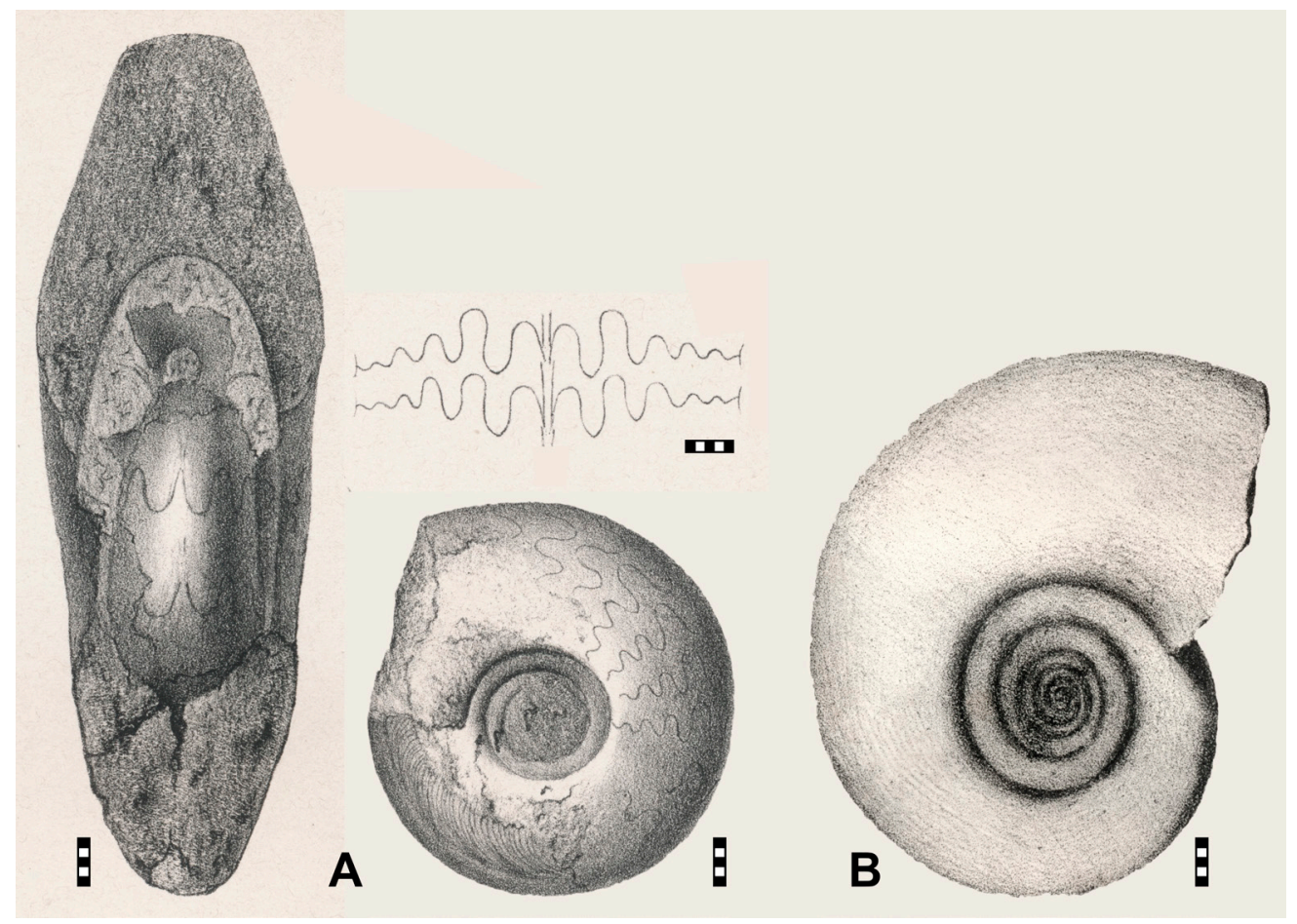

Fig. 34. Extropharciceras becheri (von Buch, 1832). A. Reproduction of the specimens illustrated by Frech (1888: pl. 2 fig. 4). B. Reproduction of the specimen illustrated by Beyrich (1837a: pl. 1 fig. 7). Scale bar units $=1 \mathrm{~mm}$. 


\section{Description}

Three specimens are selected for description and illustration:

Neotype MB.C.3609: well-preserved specimen with nearly $100 \mathrm{~mm}$ conch diameter in the contact zone between a pillow diabase and an iron-rich sparitic limestone (Fig. 32A).

MB.C.3613: slightly deformed specimen with $52 \mathrm{~mm}$ conch diameter in iron-rich sparitic limestone; the last quarter of the last volution belongs to the body chamber (Fig. 32B).

MB.C.30247: sectioned specimen with $92 \mathrm{~mm}$ conch diameter in haematitic limestone (Fig. 33A).

Neotype MB.C.3609 with nearly $100 \mathrm{~mm}$ conch diameter has an extremely discoidal and subevolute conch with a moderate coiling rate (Fig. 32A); the whorl profile is pear-shaped in the last volution with a shallow umbilical wall, a broadly rounded umbilical margin, rather strongly convergent flanks, a subangular ventrolateral shoulder and a rounded venter. The ventrolateral shoulder is much more rounded half a volution earlier (at $73 \mathrm{~mm} \mathrm{dm}$ ). A ventrolateral groove on each side is well-preserved another half whorl earlier (at $52 \mathrm{~mm} \mathrm{dm}$ ). Shell remains are preserved in the inner whorls and also on the last volution, but here only on the umbilical wall and the inner flanks. The course of the fine growth lines on the last volution is biconvex with a rather high and rounded dorsolateral projection. Inner whorls show coarser growth lines, which possess a very prominent, narrow ventrolateral projection.

MB.C.3613 has, at a diameter of $52 \mathrm{~mm}$, a discoidal and subevolute conch and a whorl profile with rather steep umbilical wall, a rounded umbilical margin, convergent flanks and a broadly rounded venter (Fig. 32B). The growth lines can be best seen in the area 270-360 degrees before the preserved aperture; their course is strongly biconvex with very prominent, very narrow ventrolateral projection. The growth lines are here superimposed by the Runzelschicht, which consists of fine wrinkles with radial direction. The outer suture line can be seen on the last preserved volution; at a conch diameter of about $39 \mathrm{~mm}$ it shows a wide external lobe with nearly parallel flanks and four V-shaped lobes on the flank, which continuously become smaller towards the umbilicus (Fig. 33B).

The sectioned specimen MB.C.30247 allows the study of the ontogenetic changes of conch geometry from the earliest whorls up to a diameter of $92 \mathrm{~mm}$ (Fig. 33A). The most conspicuous morphological change concerns the whorl profile, which is depressed in the whorls of the early and preadult stage but compressed in the adult stage. The whorl profile is widest in a growth interval between 4.5 and $18 \mathrm{~mm}$ conch diameter, when the ww/wh ratio exceeds a value of 2.00 . Up to a conch diameter of $38 \mathrm{~mm}$, the whorl profile is crescent-shaped with a very broad venter. Thereafter, the whorls become higher with narrowing of the venter. The last half whorl, between 68 and $92 \mathrm{~mm} \mathrm{dm}$, shows slightly flattened, convergent flanks that are slightly incurved in the ventrolateral area. At the largest diameter, the ventrolateral shoulders are pronounced and separate the flanks from the weakly flattened venter. The uw/dm ratio increases in early ontogeny up to $6 \mathrm{~mm} \mathrm{dm}$ to a value of 0.50 ; thereafter, a nearly continuous decrease to a value of 0.35 in the terminal stage can be observed. The coiling rate decrease in early ontogeny and slowly increases to a maximum value of 1.82 at $92 \mathrm{~mm}$ dm (Fig. 33C-F).

\section{Remarks}

The description and the figure of "Ammonites Becheri" by von Buch (1832) gives little information about the morphology of the species. Beyrich (1837a, 1837b) provided a better illustration; it shows a species with evolute inner convolutions and quite high adult whorl (Fig. 34B). Finally, Frech (1888) gave a more detailed description and illustration (Fig. 34A); the species Extropharciceras becheri is redefined here based on this description and figure. 
Table 19. Conch dimensions and ratios of selected specimens of Extropharciceras becheri (von Buch, 1832).

\begin{tabular}{ccccccccccc}
\hline Specimen & dm & ww & wh & uw & ah & ww/dm & ww/wh & uw/dm & WER & IZR \\
\hline MB.C.3609 & 97.8 & 29.0 & 36.5 & 35.0 & 26.1 & 0.30 & 0.79 & 0.36 & 1.86 & 0.28 \\
MB.C.3613 & 52.2 & 25.0 & 19.8 & 21.1 & 13.4 & 0.48 & 1.26 & 0.40 & 1.81 & 0.32 \\
MB.C.30247 & 91.83 & 30.44 & 35.30 & 31.99 & 23.73 & 0.33 & 0.86 & 0.35 & 1.82 & 0.33 \\
MB.C.30247 & 50.93 & 22.75 & 19.07 & 18.56 & 12.42 & 0.45 & 1.19 & 0.36 & 1.75 & 0.35 \\
MB.C.30247 & 29.81 & 16.55 & 10.66 & 11.87 & 6.84 & 0.56 & 1.55 & 0.40 & 1.68 & 0.36 \\
MB.C.30247 & 18.16 & 11.34 & 5.66 & 8.18 & 3.89 & 0.62 & 2.00 & 0.45 & 1.62 & 0.31 \\
MB.C.30247 & 11.41 & 7.69 & 3.36 & 5.43 & 2.27 & 0.67 & 2.29 & 0.48 & 1.56 & 0.32 \\
MB.C.30247 & 7.33 & 4.91 & 2.08 & 3.62 & 1.42 & 0.67 & 2.36 & 0.49 & 1.54 & 0.32 \\
MB.C.30247 & 4.76 & 2.87 & 1.34 & 2.20 & 0.95 & 0.60 & 2.15 & 0.46 & 1.56 & 0.29 \\
MB.C.30247 & 2.96 & 1.83 & 0.91 & 1.30 & 0.65 & 0.62 & 2.00 & 0.44 & 1.64 & 0.29 \\
MB.C.30247 & 1.79 & 1.01 & 0.56 & 0.74 & 0.39 & 0.56 & 1.79 & 0.41 & 1.64 & 0.30 \\
MB.C.30247 & 1.06 & 0.67 & 0.41 & 0.32 & 0.31 & 0.63 & 1.65 & 0.31 & 2.02 & 0.22 \\
\hline
\end{tabular}

Table 20. Conch ontogeny of Extropharciceras becheri (von Buch, 1832).

\begin{tabular}{|c|c|c|c|}
\hline dm & conch shape & whorl cross section shape & whorl expansion \\
\hline $5 \mathrm{~mm}$ & $\begin{array}{l}\text { thinly pachyconic; evolute } \\
(\mathrm{ww} / \mathrm{dm} \sim 0.60 ; \mathrm{uw} / \mathrm{dm} \sim 0.45)\end{array}$ & $\begin{array}{l}\text { strongly depressed; moderately embracing } \\
\quad(\mathrm{ww} / \mathrm{wh} \sim 2.15 ; \text { IZR } \sim 0.30)\end{array}$ & $\begin{array}{c}\text { low } \\
(\text { WER } \sim 1.55)\end{array}$ \\
\hline $10 \mathrm{~mm}$ & $\begin{array}{l}\text { thinly pachyconic; evolute } \\
\text { (ww/dm } \sim 0.70 ; \mathrm{uw} / \mathrm{dm} \sim 0.50 \text { ) }\end{array}$ & $\begin{array}{l}\text { strongly depressed; strongly embracing } \\
\quad \text { (ww/wh } \sim 2.30 ; \text { IZR } \sim 0.35 \text { ) }\end{array}$ & $\begin{array}{c}\text { low } \\
(\text { WER } \sim 1.55)\end{array}$ \\
\hline $20 \mathrm{~mm}$ & $\begin{array}{l}\text { thinly pachyconic; evolute } \\
\text { (ww/dm } \sim 0.60 ; \mathrm{uw} / \mathrm{dm} \sim 0.45 \text { ) }\end{array}$ & $\begin{array}{l}\text { moderately depressed; strongly embracing } \\
\quad(\mathrm{ww} / \mathrm{wh} \sim 1.95 ; \text { IZR } \sim 0.35)\end{array}$ & $\begin{array}{c}\text { low } \\
(\text { WER } \sim 1.60)\end{array}$ \\
\hline $40 \mathrm{~mm}$ & $\begin{array}{l}\text { thickly discoidal; subevolute } \\
\text { (ww/dm } \sim 0.50 ; \mathrm{uw} / \mathrm{dm} \sim 0.40 \text { ) }\end{array}$ & $\begin{array}{l}\text { weakly depressed; strongly embracing } \\
\quad(\text { ww } / \text { wh } \sim 1.45 ; \text { IZR } \sim 0.35)\end{array}$ & $\begin{array}{c}\text { low } \\
(\text { WER } \sim 1.70)\end{array}$ \\
\hline $80 \mathrm{~mm}$ & $\begin{array}{l}\text { thinly discoidal; subevolute } \\
\text { (ww/dm } \sim 0.35 ; \text { uw } / \mathrm{dm} \sim 0.35 \text { ) }\end{array}$ & $\begin{array}{l}\text { weakly compressed; strongly embracing } \\
\quad \text { (ww/wh } \sim 0.90 ; \mathrm{IZR} \sim 0.35 \text { ) }\end{array}$ & $\begin{array}{c}\text { moderate } \\
(\mathrm{WER} \sim 1.80)\end{array}$ \\
\hline
\end{tabular}

Extropharciceras becheri differs from E. metallicum sp. nov. from the Roteisenstein in that it has considerably wider whorls and the adult stage with a flattened venter. Differentiation from some species of Pharciceras is more difficult if the suture line is not visible. But here, too, a demarcation can be ensured by the conch form; E. becheri shows the combination of very evolute inner whorls and a flat venter, which is not known in the species of Pharciceras from the Roteisenstein.

Extropharciceras becheri has some similarity in the shape of the conch to Allopharciceras maximum from the Anti-Atlas of Morocco (Bockwinkel et al. 2017), but differs in the ontogeny of the suture, which shows irregular insertion of umbilical lobes in A. maximum.

Genus Lunupharciceras Korn in Korn \& Klug, 2002

\section{Type species}

Goniatites lunulicosta Sandberger \& Sandberger, 1850 (original designation). 


\section{Diagnosis}

Pharciceratinae with discoidal subevolute to evolute juvenile stage, whorl profile weakly depressed. Adult stage discoidal and subevolute to evolute with compressed whorl profile; WER moderate, venter rounded or tabulate. Adult stage with or without ventrolateral grooves. Suture line with wide external lobe, short $\mathrm{E}_{1}$ lobe, high median saddle, deep lanceolate $\mathrm{E}_{2}$ lobe, smaller lanceolate lateral lobe, three outer and two or three inner umbilical lobes. Suture line formula sequence of the five or six U lobes so far ambiguous and controversial.

\section{Included species}

Goniatites lunulicosta Sandberger \& Sandberger, 1850, Rhenish Mountains; Schindewolfoceras alcaldei Montesinos \& Henn, 1986, Cantabrian Mountains; Lunupharciceras incisum Bockwinkel, Becker \& Ebbighausen, 2013, Anti-Atlas; Prolecanites Kiliani Frech, 1902, Montagne Noire; Lunupharciceras serpentinum Bockwinkel, Becker \& Ebbighausen, 2009, Anti-Atlas; Lunupharciceras kochi sp. nov., Rhenish Mountains.

\section{Lunupharciceras lunulicosta (Sandberger \& Sandberger, 1850)}

Figs 35-38; Tables 21-22

Goniatites lunulicosta Sandberger \& Sandberger, 1850: 69, pl. 3 figs 14, 14a-14f.

Goniatites (Prolecanites) lunulicosta - Frech 1888: 27, pl. 2 fig. 3.

Prolecanites lunulicosta - Frech 1897: 177e, fig. 2d; 1902: 64, fig. 21d.

Pharciceras lunulicosta - Wedekind 1918: 127, pl. 20 fig. 6. - Matern 1931: 89. - House \& Ziegler 1977: 88, pl. 5 fig. 15.

Lunupharciceras lunulicosta - Korn \& Klug 2002: 145, text-fig. 134d (only). - Bockwinkel et al. 2013a: 36, text-figs 35a, 36a (only).

non Pharciceras lunulicosta - Petter 1959: 132, pl. 7 figs 2-4, pl. 26 fig. 4, text-fig. 17.

non Lunupharciceras lunulicosta - Korn \& Klug 2002: text-fig. 134b. - Bockwinkel et al. 2013a: 36, text-figs 35b-f, 36b-c.

\section{Diagnosis}

Lunupharciceras with thinly discoidal, subevolute conch at $20 \mathrm{~mm} \mathrm{dm}(\mathrm{ww} / \mathrm{dm} \sim 0.35$; uw/ $\mathrm{dm} \sim 0.35)$ and extremely discoidal, subevolute conch at $40 \mathrm{~mm} \mathrm{dm} \mathrm{(ww/dm} \sim 0.30 ; \mathrm{uw} / \mathrm{dm} \sim 0.35)$. Whorl profile nearly circular (ww/wh $\sim 1.00$ ) at $20 \mathrm{~mm} \mathrm{dm}$ and compressed at $40 \mathrm{~mm} \mathrm{dm} \mathrm{(ww/dm} \sim 0.70$ ). Umbilical wall steep, umbilical margin rounded, flanks converging to the continuously rounded venter. Whorl profile in the adult stage with weakly concave outer flanks, pronounced ventrolateral shoulder and weakly flattened venter. Adult stage with short ventrolateral riblets. Suture line with parallel-sided, slightly blunt $\mathrm{E}_{2}, \mathrm{~L}, \mathrm{U}_{2}$ and $\mathrm{U}_{4}$ lobes.

\section{Material examined}

\section{Lectotype}

GERMANY - Rhenish Mountains, Oberscheld; late Givetian (Red Ironstone); Lotz 1901-1902 Coll.; specimen 27c (Wiesbaden Museum), designated by House in House \& Ziegler (1977); illustrated by Sandberger \& Sandberger (1850-1856: pl. 3 fig. 14a) and House \& Ziegler (1977: pl. 5 fig. 15); Wiesbaden Museum nr. 27c ( Fig. 35C) 
Additional material

GERMANY • 2 specimens; Rhenish Mountains, Oberscheld; late Givetian (Red Ironstone); Lotz 19011902 Coll.; 27a, 27b (Wiesbaden Museum) • 2 specimens; Rhenish Mountains, Oberscheld, Beilstein; late Givetian (Red Ironstone); Beyrich 1835 Coll.; MB.C.3641, MB.C.5603 • 27 specimens; Rhenish Mountains, Oberscheld (Grube Sahlgrund, $420 \mathrm{~m}$ Sohle); late Givetian (Red Ironstone); Kegel 1927 Coll.; MB.C.3642, MB.C.3648, MB.C.3666, MB.C.3667, MB.C.30250.1 to 30250.23 • 3 specimens; Rhenish Mountains, Oberscheld; late Givetian (Red Ironstone); Erbreich, Kauth Coll.; MB.C.7690, MB.C.22121, MB.C.22171 • 1 specimen; Rhenish Mountains, Oberscheld (Grube Volpertseiche); late Givetian (Red Ironstone); Lotz 1902 Coll.; MB.C.30249 • 1 specimen; Rhenish Mountains, Oberscheld (Westfeld der Grube Königszug, Firste der 120-150 m Sohle); late Givetian (Red Ironstone); Ahlburg Coll.; MB.C.30251.

\section{Description}

Nine specimens are selected for description and illustration:

27a: body chamber fragment with $75 \mathrm{~mm}$ conch diameter in dark purple limestone; the specimen was probably used for a combination figured by Sandberger \& Sandberger (1850-1856: pl. 3 fig. 14) (Fig. 35E).
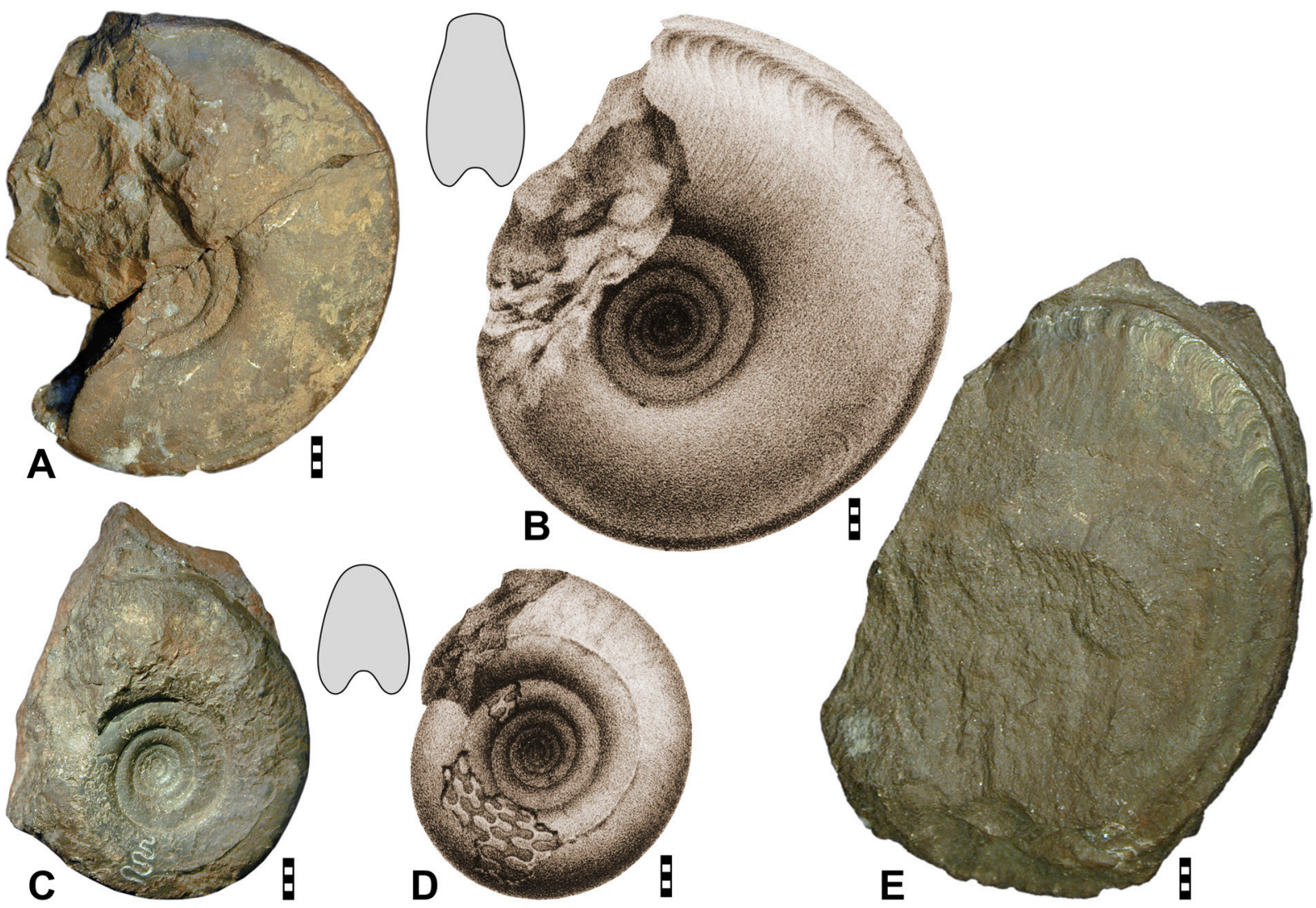

Fig. 35. Lunupharciceras lunulicosta (Sandberger \& Sandberger, 1850). A. Syntype 27b from Oberscheld in the Wiesbaden Museum. B. Probably a combination of syntypes 27a and 27b in the Wiesbaden Museum, reproduction of the figures in Sandberger \& Sandberger (1850-1856: pl. 3 figs 14, 14f). C. Lectotype 27c from Oberscheld in the Wiesbaden Museum. D. Lectotype 27c in the Wiesbaden Museum; reproduction of the figures in Sandberger \& Sandberger (1850-1856: pl. 3 fig. 14a, g). E. Syntype 27a from Oberscheld in the Wiesbaden Museum. Scale bar units $=1 \mathrm{~mm}$. 
27b: incomplete specimen with $57 \mathrm{~mm}$ conch diameter in red limestone; the specimen was probably used for a combination figured by Sandberger \& Sandberger (1850-1856, pl. 3 fig. 14) (Fig. 35A).

Lectotype 27c: incomplete, rather strongly weathered specimen with $42 \mathrm{~mm}$ conch diameter in red limestone; the suture line is visible. The specimen was figured by Sandberger \& Sandberger (18501856: pl. 3 fig. 14a) (Fig. 35C).

MB.C.3642: weakly deformed specimen with $57 \mathrm{~mm}$ conch diameter in iron-rich micritic limestone; phragmocone filled with sparry calcite. Half of the last whorl belongs to the body chamber, the last suture line is well exposed at the calcite-micrite contact (Fig. 36A).

MB.C.3648: fully chambered steinkern specimen of $50 \mathrm{~mm}$ conch diameter in weathered iron-rich limestone (Fig. 36B).

MB.C.22171: incomplete fully septate specimen with $37 \mathrm{~mm}$ conch diameter in red ironstone (Fig. 36C).

MB.C.3666: incomplete specimen with $36 \mathrm{~mm}$ conch diameter in iron-rich micritic limestone (Fig. 36D).

MB.C.3667: incomplete specimen with $30 \mathrm{~mm}$ conch diameter in iron-rich micritic limestone (Fig. 36E).
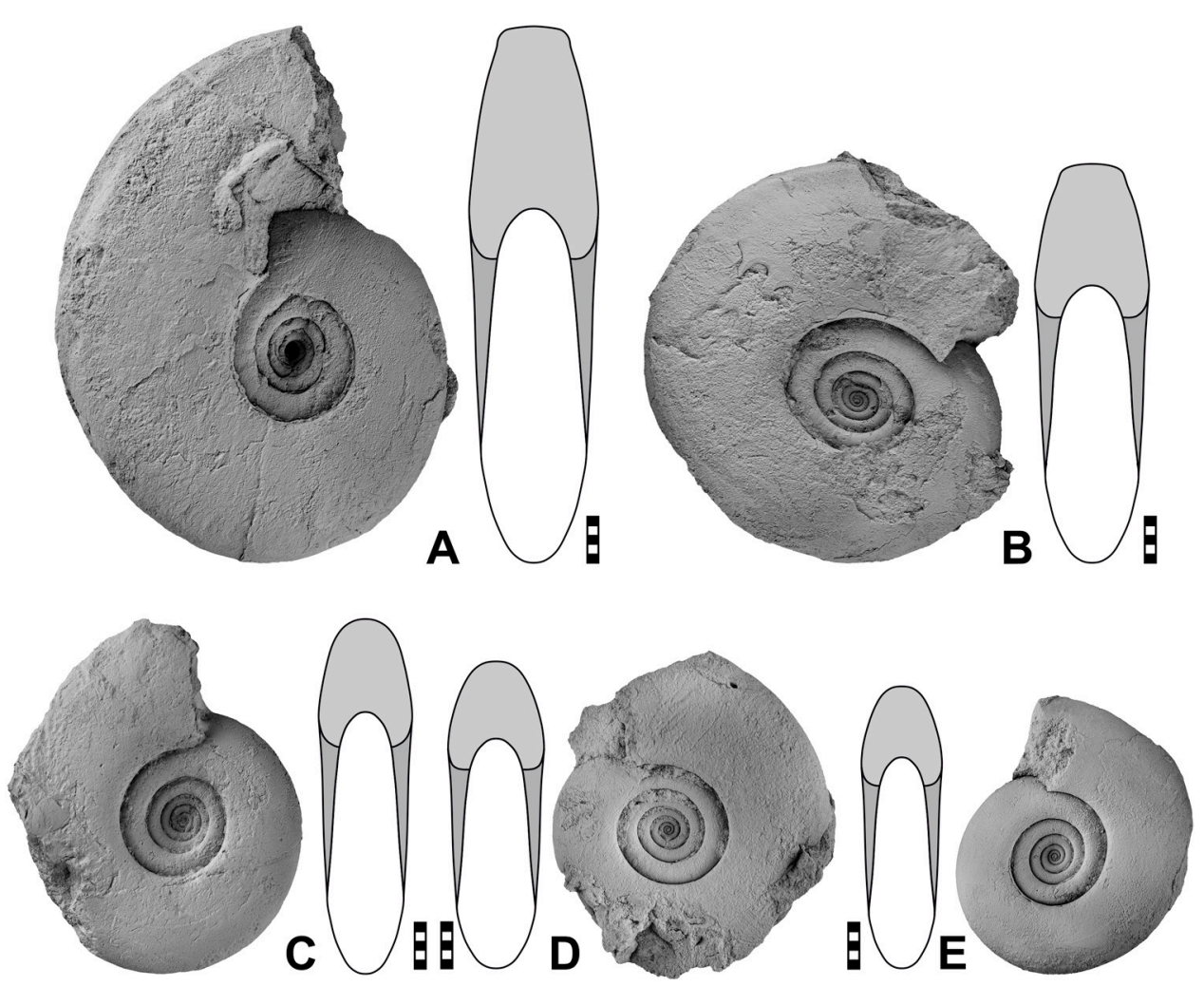

Fig. 36. Lunupharciceras lunulicosta (Sandberger \& Sandberger, 1850). A. Specimen MB.C.3642 (Kegel 1927 Coll.) from Oberscheld (Sahlgrund Mine). B. Specimen MB.C.3648 (Kegel 1927 Coll.) from Oberscheld (Sahlgrund Mine). C. Specimen MB.C.22171 (Kauth Coll.) from Oberscheld. D. Specimen MB.C.3666 (Kegel 1927 Coll.) from Oberscheld (Sahlgrund Mine). E. Specimen MB.C.3667 (Kegel 1927 Coll.) from Oberscheld (Sahlgrund Mine). Scale bar units $=1 \mathrm{~mm}$. 
MB.C.22121 is sectioned and shows the conch ontogeny from the initial stage up to a conch diameter of $31 \mathrm{~mm}$ (Fig. 37A).

The cross section of specimen MB.C.22121 demostrates that the trajectories of the conch parameters are very different (Fig. 37A): while the ww/dm trajectory is nearly monophasic with a rather continuous decrease from 0.55 at $1 \mathrm{~mm}$ dm to 0.33 at $31 \mathrm{~mm} \mathrm{dm}$, the uw/dm trajectory has an irregular undulating course with values ranging between 0.40 and 0.50 . The coiling rate is rather high (1.88-2.01) in the early juvenile stage up to $4 \mathrm{~mm} \mathrm{dm}$, it is lower (down to 1.64 at $7 \mathrm{~mm} \mathrm{dm}$ ) and shows a subsequent increase to nearly 2.00 at $31 \mathrm{~mm} \mathrm{dm}$.

The largest available specimen MB.C.3642 (Fig. 36A) with $57 \mathrm{~mm}$ conch diameter allows the study of the adult stage. The conch is extremely discoidal and subinvolute with a high coiling rate; the whorl profile is compressed with a steep umbilical wall, subparallel flanks and rounded venter on the first three quarters of the last volution. At the largest diameter of the specimen, the venter is slightly flattened and
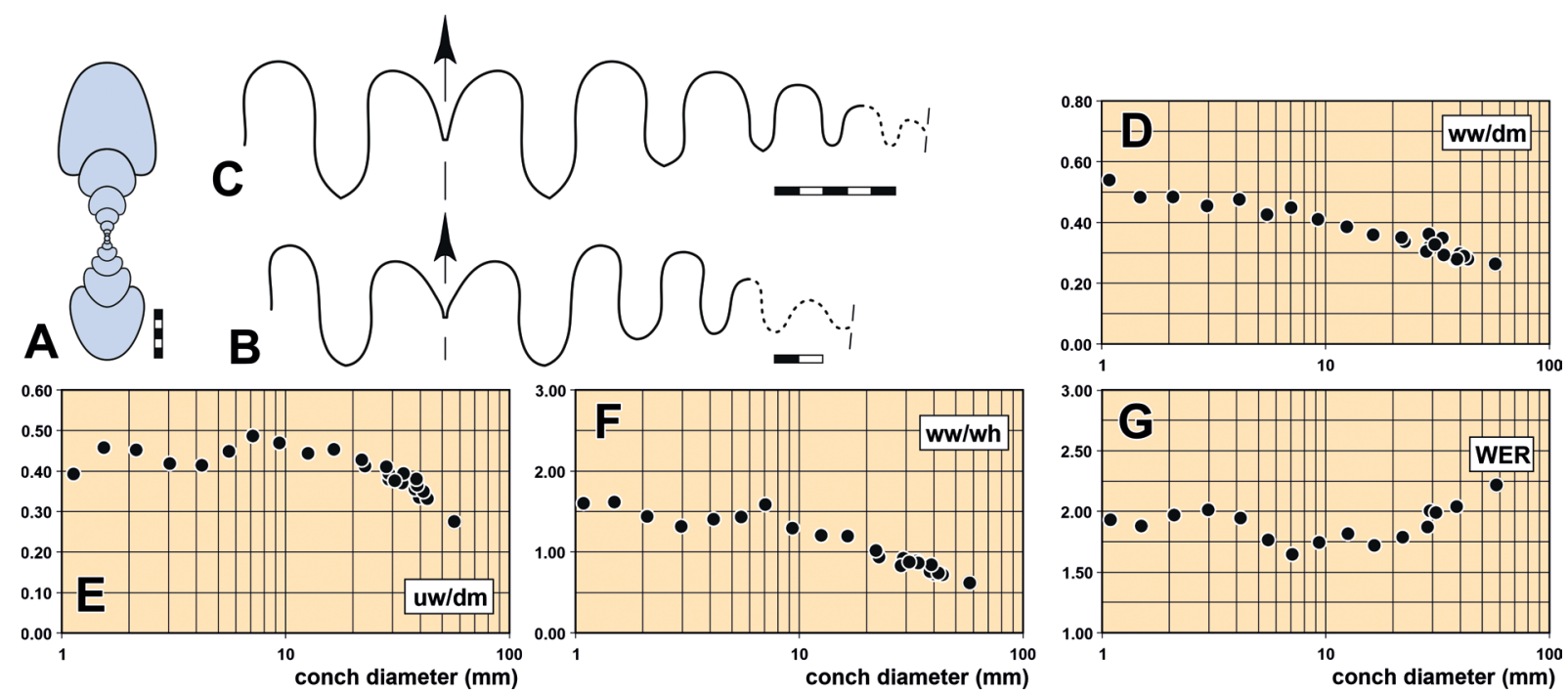

Fig. 37. Lunupharciceras lunulicosta (Sandberger \& Sandberger, 1850). A. Cross section of specimen MB.C.22121 from Oberscheld. B. Suture line of specimen MB.C.3642 (Kegel 1927 Coll.) from Oberscheld (Sahlgrund Mine), at $\mathrm{dm}=35.0 \mathrm{~mm}, \mathrm{ww}=10.5 \mathrm{~mm}$, wh $=14.5 \mathrm{~mm}$. C. Suture line of specimen MB.C.3648 (Kegel 1927 Coll.) from Oberscheld (Sahlgrund Mine), at $\mathrm{dm}=42.0 \mathrm{~mm}$, ww $=12.5 \mathrm{~mm}$, wh $=16.5 \mathrm{~mm}$. D-G. Ontogeneric trajectories of the cardinal conch parameters. Abbreviations: see Material and methods. Scale bar units $=1 \mathrm{~mm}$.

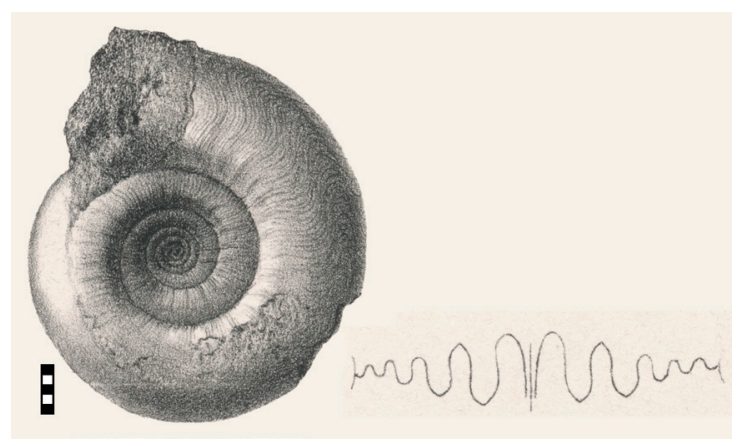

Fig. 38. Lunupharciceras lunulicosta (Sandberger \& Sandberger, 1850); reproduction of the specimen illustrated by Frech (1888: pl. 2 fig. 3). Scale bar units $=1 \mathrm{~mm}$. 
Table 21. Conch dimensions and ratios of selected specimens of Lunupharciceras lunulicosta (Sandberger \& Sandberger, 1850).

\begin{tabular}{ccccccccccc}
\hline Specimen & dm & ww & wh & uw & ah & ww/dm & ww/wh & uw/dm & WER & IZR \\
\hline MB.C.3642 & 57.3 & 15.1 & 25.1 & 15.7 & 18.8 & 0.26 & 0.60 & 0.27 & 2.22 & 0.25 \\
MB.C.3648 & 43.3 & 12.1 & 17.2 & 14.4 & - & 0.28 & 0.70 & 0.33 & - & - \\
Wiesbaden 27c & 38.7 & 10.8 & 13.0 & 14.7 & - & 0.28 & 0.83 & 0.38 & - & - \\
MB.C.22171 & 38.1 & 10.5 & 14.1 & 13.5 & 11.4 & 0.28 & 0.74 & 0.35 & 2.04 & 0.19 \\
MB.C.3666 & 29.0 & 10.5 & 11.5 & 11.4 & 8.5 & 0.36 & 0.91 & 0.39 & 2.00 & 0.26 \\
MB.C.3667 & 28.3 & 8.6 & 10.5 & 11.6 & 7.6 & 0.30 & 0.82 & 0.41 & 1.87 & 0.28 \\
MB.C.22121 & 30.83 & 10.08 & 11.67 & 11.57 & 8.96 & 0.33 & 0.86 & 0.38 & 1.99 & 0.23 \\
MB.C. 22121 & 16.38 & 5.88 & 4.94 & 7.42 & 3.88 & 0.36 & 1.19 & 0.45 & 1.72 & 0.22 \\
MB.C.22121 & 9.28 & 3.81 & 2.94 & 4.36 & 2.25 & 0.41 & 1.29 & 0.47 & 1.74 & 0.24 \\
MB.C.22121 & 5.49 & 2.34 & 1.63 & 2.46 & 1.36 & 0.43 & 1.43 & 0.45 & 1.76 & 0.17 \\
\hline
\end{tabular}

Table 22. Conch ontogeny of Lunupharciceras lunulicosta (Sandberger \& Sandberger, 1850).

\begin{tabular}{|c|c|c|c|}
\hline dm & conch shape & whorl cross section shape & whorl expansion \\
\hline $5 \mathrm{~mm}$ & $\begin{array}{l}\text { thinly discoidal; subevolute } \\
\text { (ww/dm } \sim 0.45 ; \mathrm{uw} / \mathrm{dm} \sim 0.40 \text { ) }\end{array}$ & $\begin{array}{l}\text { weakly depressed; moderately embracing } \\
\quad \text { (ww/wh } \sim 1.45 ; \text { IZR } \sim 0.20 \text { ) }\end{array}$ & $\begin{array}{c}\text { moderate } \\
(\mathrm{WER} \sim 1.80)\end{array}$ \\
\hline $10 \mathrm{~mm}$ & $\begin{array}{l}\text { thinly discoidal; evolute } \\
\text { (ww/dm } \sim 0.40 ; \mathrm{uw} / \mathrm{dm} \sim 0.45 \text { ) }\end{array}$ & $\begin{array}{l}\text { weakly depressed; moderately embracing } \\
\quad(\mathrm{ww} / \mathrm{wh} \sim 1.25 ; \mathrm{IZR} \sim 0.25 \text { ) }\end{array}$ & $\begin{array}{c}\text { moderate } \\
(\mathrm{WER} \sim 1.80)\end{array}$ \\
\hline $20 \mathrm{~mm}$ & $\begin{array}{l}\text { thinly discoidal; subevolute } \\
\text { (ww/dm } \sim 0.35 ; \mathrm{uw} / \mathrm{dm} \sim 0.35 \text { ) }\end{array}$ & $\begin{array}{l}\text { weakly depressed; moderately embracing } \\
\quad \text { (ww/wh } \sim 1.05 ; \text { IZR } \sim 0.25 \text { ) }\end{array}$ & $\begin{array}{c}\text { moderate } \\
(\mathrm{WER} \sim 1.80)\end{array}$ \\
\hline $40 \mathrm{~mm}$ & $\begin{array}{l}\text { extremely discoidal; subevolute } \\
(\mathrm{ww} / \mathrm{dm} \sim 0.30 ; \mathrm{uw} / \mathrm{dm} \sim 0.35)\end{array}$ & $\begin{array}{l}\text { weakly compressed; moderately embracing } \\
\qquad(\mathrm{ww} / \mathrm{wh} \sim 0.75 ; \mathrm{IZR} \sim 0.20)\end{array}$ & $\begin{array}{c}\text { high } \\
(\mathrm{WER} \sim 2.05)\end{array}$ \\
\hline
\end{tabular}

separated from the flanks by a pronounced ventrolateral shoulder. Shell ornament is not preserved, but at some places, impressions of strengthened growth lines can be seen on the outer flanks. The suture line has, at $35 \mathrm{~mm}$ conch diameter, a very wide external lobe with parallel-sided, blunt prongs, a parallelsided, rounded lateral lobe and a smaller $\mathrm{U}_{2}$ lobe of the same shape (Fig. 37B).

Specimen MB.C.3648 (Fig. 36B) shows the morphological change from the widely umbilicate juvenile stage to the more involute adult stage. The conch is extremely discoidal and subevolute with high coiling rate; the whorl profile is compressed with a rounded umbilical wall, subparallel flanks and rounded venter. The suture line has, at $42 \mathrm{~mm}$ phragmocone diameter, a wide parallel-sided external lobe with lanceolate prongs. Four lobes are visible on the flanks and umbilical wall; while the lateral lobe is lanceolate and acute, the $\mathrm{U}_{2}-\mathrm{U}_{6}$ lobes are rounded (Fig. 37C).

Specimens MB.C.22171 (37 mm conch diameter), MB.C.3666 (29 mm) and MB.C.3667 (29 mm) demonstrate the decrease of the umbilical width ratio, which parallels the whorl profile becoming more compressed. Specimen MB.C.3666 shows the shell ornament with fine, biconvex growth lines that possess a high ventrolateral projection and a deep ventral sinus, while specimen MB.C.3667 appears to be smooth.

\section{Remarks}

Lunupharciceras lunulicosta differs from the co-occurring L. kochi sp. nov. in the narrower umbilicus. Lunupharciceras lunulicosta is subevolute at $20 \mathrm{~mm}$ conch diameter (uw/dm $\sim 0.40$ ), while L. kochi 
sp. nov. is still evolute (uw/ $\mathrm{dm} \sim 0.47$ ). At $50 \mathrm{~mm}$ conch diameter, the difference is even larger (uw $/ \mathrm{dm}$ $\sim 0.30$ in L. lunulicosta but more than 0.40 in L. kochi sp. nov.). The difference in the umbilical width can easily be seen in specimens in which the matrix has been cleaned from the umbilicus.

The material attributed by Bockwinkel et al. (2013a) to L. lunulicosta is fragmentary and difficult to assign. It can therefore not be determined whether it actually belongs to this species.

Lunupharciceras kochi sp. nov. urn:lsid:zoobank.org:act:8A30D64E-E259-4EAA-8368-5EAEE216FA9F

Figs 39-40; Tables 23-24

\section{Diagnosis}

Lunupharciceras with extremely discoidal, evolute conch at $20 \mathrm{~mm} \mathrm{dm}(\mathrm{ww} / \mathrm{dm} \sim 0.30$; $\mathrm{uw} / \mathrm{dm} \sim 0.47)$ and extremely discoidal, subevolute conch at $40 \mathrm{~mm} \mathrm{dm}$ (ww/ $\mathrm{dm} \sim 0.28 ; \mathrm{uw} / \mathrm{dm} \sim 0.42$ ). Whorl profile nearly circular (ww/wh $\sim 1.00$ ) at $20 \mathrm{~mm} \mathrm{dm}$ and compressed at $40 \mathrm{~mm} \mathrm{dm} \mathrm{(ww/dm} 0.70$ ). WER moderate. Umbilical wall steep, umbilical margin rounded, flanks converging to the continuously rounded venter. Whorl profile in the adult stage with weakly concave outer flanks, pronounced, subangular ventrolateral shoulder and weakly flattened venter. Without or with very weak ventrolateral riblets. Suture line with lanceolate $\mathrm{E}_{2}$ and L lobes, three outer U lobes, the first and second U-shaped, the third small and asymmertric.

\section{Etymology}

Named after Carl Koch (1827-1882), who assembled a large collection of Roteisenstein fossils including the type of the new species.

\section{Material examined}

Holotype

GERMANY • Rhenish Mountains, Langenaubach (Grube Constanze); late Givetian (Red Ironstone); Koch Coll.; MB.C.3627. (Fig. 39A)

\section{Paratypes}

GERMANY - 3 specimens; Rhenish Mountains, Langenaubach (Grube Constanze); late Givetian (Red Ironstone); Stein Coll.; MB.C.22185 to 22187 • 2 specimens; Rhenish Mountains, Oberscheld (Grube Anna); late Givetian (Red Ironstone); Koch Coll.; MB.C.3628, MB.C.30252 - 1 specimen; Rhenish Mountains, Dillenburg; late Givetian (Red Ironstone); Kauth Coll.; MB.C.22177 • 1 specimen; Rhenish Mountains, Oberscheld (Grube Neuerburg); late Givetian (Red Ironstone); Emmel 1906 Coll.; MB.C.3611 • 1 specimen; Rhenish Mountains, Oberscheld; late Givetian (Red Ironstone); MB.C.7632 • 1 specimen; Rhenish Mountains, Oberscheld, Sessacker; late Givetian (Red Ironstone); Dannenberg Coll.; MB.C.22196 • 1 specimen; Rhenish Mountains, Oberscheld (Grube Königszug); late Givetian (Red Ironstone); Dannenberg Coll.; MB.C.30253 • 1 specimen; Rhenish Mountains, Oberscheld (Grube Prinzkessel, 100 m Sohle); late Givetian (Red Ironstone); Lotz 1902 Coll.; MB.C.22181.

\section{Description}

Five specimens are selected for description and illustration:

Holotype MB.C.3627: incomplete, laterally partly deformed specimen with $83 \mathrm{~mm}$ conch diameter in sparitic, iron-rich limestone. It is a steinkern in which the right side is better preserved than the left side, the penultimate whorl shows suture lines. The last half of the terminal volution belongs to the body chamber (Fig. 39A). 
Paratype MB.C.22186: incomplete specimen with $57 \mathrm{~mm}$ conch diameter in haematitic ironstone; about half of the last volution belongs to the body chamber (Fig. 39B).

Paratype MB.C.3628: rather well-preserved, fully septate, exfoliated specimen with $50 \mathrm{~mm}$ conch diameter in sparitic, iron-rich limestone (Fig. 39C).

Paratype MB.C.22177: rather well-preserved, fully septate, largely exfoliated specimen with $27 \mathrm{~mm}$ conch diameter in sparitic, iron-rich limestone (Fig. 39D).

Paratype MB.C.22181: rather well-preserved steinkern specimen with $24 \mathrm{~mm}$ conch diameter preserved haematitic ironstone (Fig. 39E).
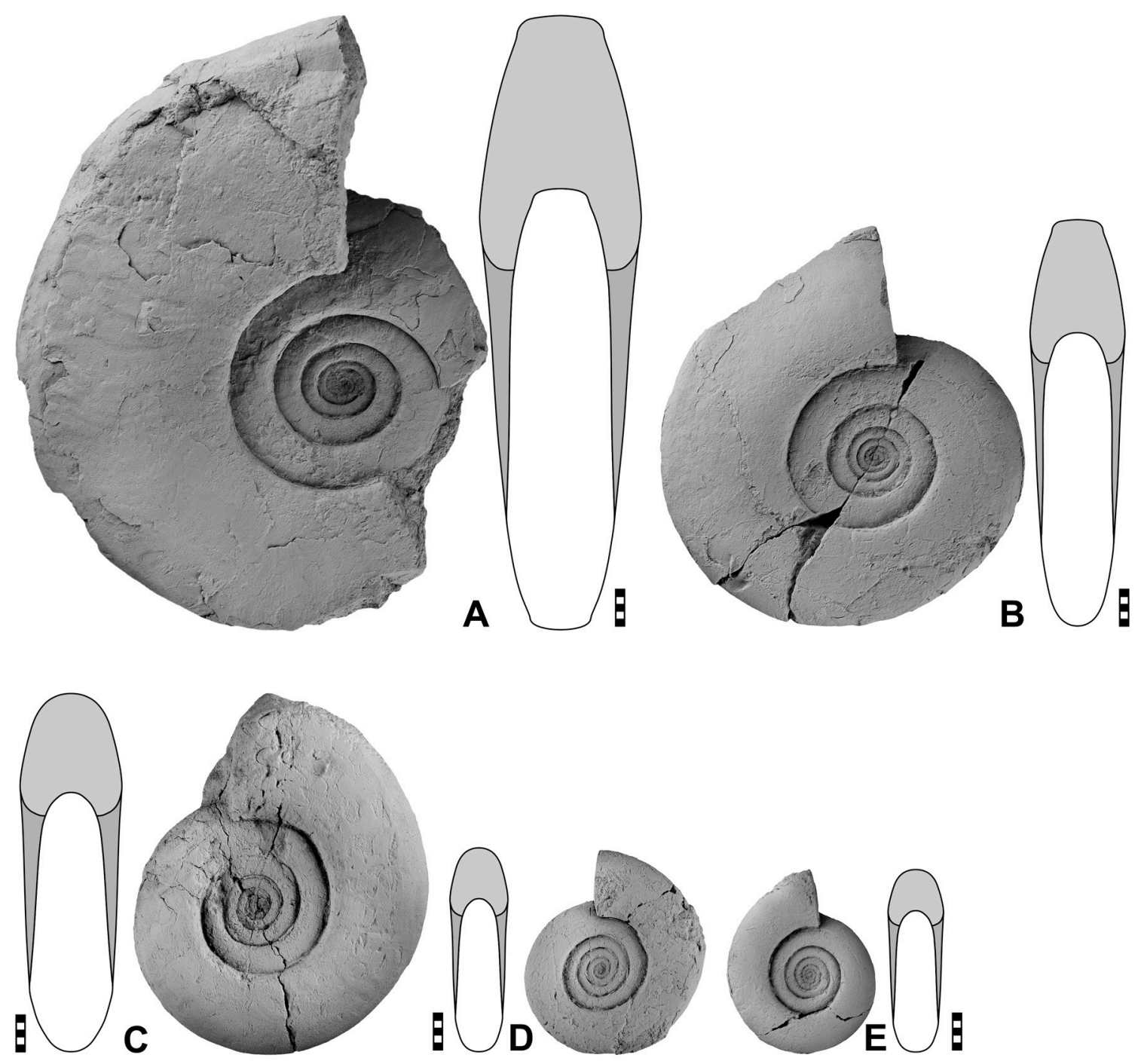

Fig. 39. Lunupharciceras kochi sp. nov. A. Holotype MB.C.3627 (Koch Coll.) from Langenaubach (Constanze Mine). B. Paratype MB.C.22186 (Stein Coll.) from Langenaubach (Constanze Mine). C. Paratype MB.C.3628 (Koch Coll.) from Oberscheld (Anna Mine). D. Paratype MB.C.22177 (Kauth Coll.) from Dillenburg. E. Paratype MB.C.22181 (Lotz 1902 Coll.) from Oberscheld (Prinzkessel Mine). Scale bar units $=1 \mathrm{~mm}$. 
Holotype MB.C.3627 with $83 \mathrm{~mm}$ conch diameter has a conch that is extremely discoidal and subevolute; the whorl profile is compressed and widest near the umbilical shoulder. The coiling rate is moderate, the umbilical wall is shallow and rounded and the flanks converge slowly towards the angular ventrolateral shoulder that delimits the flank from the slightly flattened venter (Fig. 39A). The steinkern shows traces of rhythmically strengthened growth lines, producing shallow folds on flanks and venter. These folds are particularly strong on the outer flank. Course of the growth lines is strongly biconvex with a rather high and wide dorsolateral projection, a shallow lateral sinus, and a narrow ventrolateral projection. The inner whorls appear to be smooth, but they are not well-preserved. However, they demonstrate that the conch shape of the juvenile stage is strikingly different from the adult stage, as it is serpenticonic with slowly expanding volutions.

The smaller paratype MB.C.22186 with $57 \mathrm{~mm}$ conch diameter shows the transformation from the preadult to the adult stage. It also has an extremely discoidal and subevolute conch with moderate coiling rate; the whorl profile is compressed with steep umbilical wall, rounded umbilical margin, and flattened, slowly converging flanks and narrowly rounded venter. Lamellar, biconvex growth lines are visible (Fig. 39B).

Specimen MB.C.22181 with $24 \mathrm{~mm}$ conch diameter allows the description of an intermediate growth stage. It has a discoidal and evolute conch; the whorl profile is nearly circular with oblique umbilical wall, flanks and venter broadly rounded (Fig. 39E). No traces of ventrolateral spiral grooves are visible.

The suture line of paratype MB.C.3628 has, at $44 \mathrm{~mm}$ phragmocone diameter, a general meandering outline with a high median saddle that attains more than $80 \%$ of the external lobe depth (Fig. 40A). The prong of the E lobe as well as the shorter lateral lobe are lanceolate and weakly pouched with a pointed base. They are separated by a weakly inflated, narrow ventrolateral saddle. There are three umbilical lobes on the flank; they are much shorter than the lateral lobe. The first two are U-shaped and the third is small and asymmetric.

\section{Remarks}

Lunupharciceras lunulicosta has a similar adult conch shape, but differs from L. kochi sp. nov. in its narrower umbilicus. L. lunulicosta is subevolute at $20 \mathrm{~mm}$ conch diameter (uw/ $\mathrm{dm} \sim 0.40$ ), while
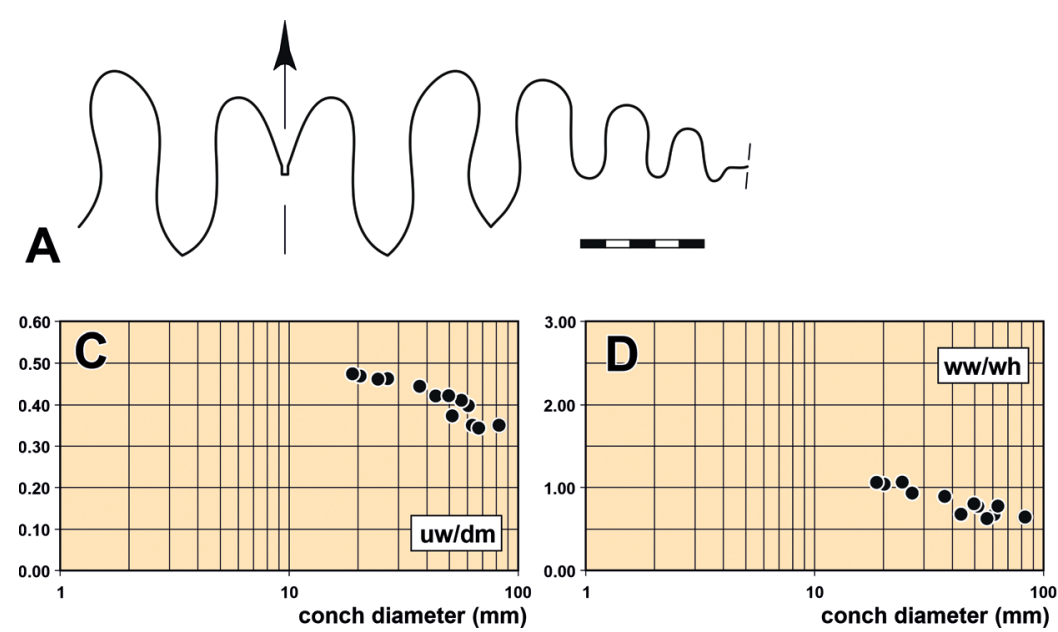
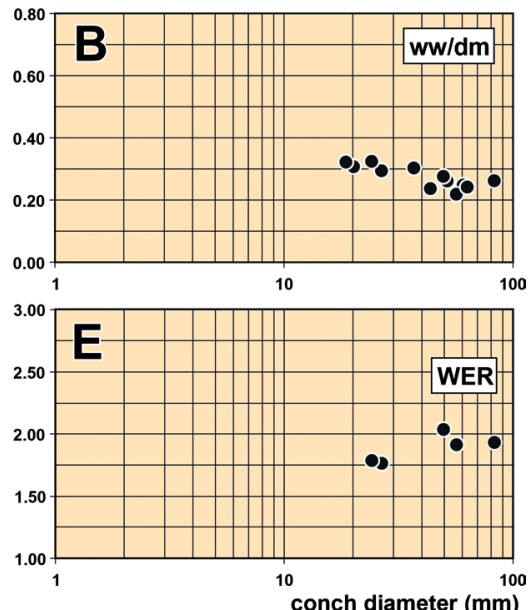

Fig. 40. Lunupharciceras kochi sp. nov. A. Suture line of paratype MB.C.3628 (Koch Coll.) from Oberscheld (Anna Mine), at $\mathrm{dm}=44.5 \mathrm{~mm}, \mathrm{ww}=13.0 \mathrm{~mm}$, wh $=14.3 \mathrm{~mm}$. B-E. Ontogeneric trajectories of the cardinal conch parameters. Abbreviations: see Material and methods. Scale bar units $=1 \mathrm{~mm}$. 
KORN D. \& BOCKWINKEL J., Ammonoids from the Roteisenstein Formation

Table 23. Conch dimensions and ratios of selected specimens of Lunupharciceras kochi sp. nov.

\begin{tabular}{ccccccccccc}
\hline Specimen & dm & ww & wh & uw & ah & ww/dm & ww/wh & uw/dm & WER & IZR \\
\hline MB.C. 3627 & 82.9 & 21.9 & 34.4 & 29.1 & 23.3 & 0.26 & 0.64 & 0.35 & 1.93 & 0.32 \\
MB.C. 22186 & 56.6 & 12.5 & 20.3 & 23.3 & 15.7 & 0.22 & 0.62 & 0.41 & 1.92 & 0.23 \\
MB.C.3628 & 49.7 & 13.8 & 17.3 & 21.0 & 14.9 & 0.28 & 0.80 & 0.42 & 2.04 & 0.14 \\
MB.C. 22177 & 26.7 & 7.9 & 8.5 & 12.4 & 6.6 & 0.30 & 0.93 & 0.46 & 1.76 & 0.22 \\
MB.C.22181 & 24.2 & 7.9 & 7.4 & 11.2 & 6.1 & 0.33 & 1.07 & 0.46 & 1.79 & 0.18 \\
\hline
\end{tabular}

Table 24. Conch ontogeny of Lunupharciceras kochi sp. nov.

\begin{tabular}{|c|c|c|c|}
\hline dm & conch shape & whorl cross section shape & whorl expansion \\
\hline $20 \mathrm{~mm}$ & $\begin{array}{l}\text { extremely discoidal; evolute } \\
(\mathrm{ww} / \mathrm{dm} \sim 0.30 ; \mathrm{uw} / \mathrm{dm} \sim 0.47)\end{array}$ & $\begin{array}{l}\text { weakly depressed; moderately embracing } \\
\text { (ww/wh } \sim 1.05 ; \text { IZR } \sim 0.20 \text { ) }\end{array}$ & $\begin{array}{c}\text { low } \\
(\text { WER } \sim 1.70)\end{array}$ \\
\hline $40 \mathrm{~mm}$ & $\begin{array}{l}\text { extremely discoidal; subevolute } \\
\text { (ww/dm } \sim 0.28 ; \mathrm{uw} / \mathrm{dm} \sim 0.42 \text { ) }\end{array}$ & $\begin{array}{l}\text { weakly compressed; moderately embracing } \\
\text { (ww/wh } \sim 0.70 ; \text { IZR } \sim 0.20 \text { ) }\end{array}$ & $\begin{array}{c}\text { moderate } \\
(\mathrm{WER} \sim 1.95)\end{array}$ \\
\hline $60 \mathrm{~mm}$ & $\begin{array}{l}\text { extremely discoidal; subevolute } \\
\text { (ww/dm } \sim 0.25 ; \mathrm{uw} / \mathrm{dm} \sim 0.35 \text { ) }\end{array}$ & $\begin{array}{l}\text { weakly compressed; moderately embracing } \\
\text { (ww/wh } \sim 0.65 \text {; IZR } \sim 0.20)\end{array}$ & $\begin{array}{c}\text { moderate } \\
(\mathrm{WER} \sim 1.95)\end{array}$ \\
\hline
\end{tabular}

L. kochi sp. nov. is still evolute (uw/ dm $\sim 0.47$ ). At $50 \mathrm{~mm}$ conch diameter, the difference is even larger (uw / dm $\sim 0.30$ in L. lunulicosta but more than 0.40 in L. kochi sp. nov.).

Subfamily Synpharciceratinae Schindewolf, 1940

\section{Diagnosis}

Pharciceratidae with closure of the umbilicus in the adult stage. Suture line with six to twenty umbilical lobes.

\section{Genera included}

Synpharciceras Schindewolf, 1940; Meropharciceras Becker \& House, 1993; Neopharciceras Bogoslovsky, 1955; Pluripharciceras Bockwinkel, Becker \& Ebbighausen, 2013; Stenopharciceras Montesinos \& Henn, 1986.

Genus Stenopharciceras Montesinos \& Henn, 1986

\section{Type species}

Pharciceras tridens var. kseirense Termier \& Termier, 1950 (original designation).

\section{Diagnosis}

Synpharciceratinae with thickly discoidal to thinly pachyconic, subevolute to evolute juvenile stage, whorl profile depressed. Adult stage subinvolute to involute by closure of the umbilicus by shell flares; whorl profile compressed, venter rounded. Adult stage without ventrolateral grooves. Suture line with wide external lobe, short bell- or funnel-shaped $\mathrm{E}_{1}$ lobe, high median saddle, deep lanceolate $\mathrm{E}_{2}$ lobe, smaller pointed lateral lobe, three or four outer and up to five inner umbilical lobes. Suture line formula $\left(\mathrm{E}_{2} \mathrm{E}_{1} \mathrm{E}_{2}\right) \mathrm{L} \mathrm{U}_{2} \mathrm{U}_{4} \mathrm{U}_{6}: \mathrm{U}_{5} \mathrm{U}_{3} \mathrm{U}_{1} \mathrm{I}$ to $\left(\mathrm{E}_{2} \mathrm{E}_{1} \mathrm{E}_{2}\right) \mathrm{L} \mathrm{U}_{2} \mathrm{U}_{4} \mathrm{U}_{6} \mathrm{U}_{8} \mathrm{U}_{9} \mathrm{U}_{7} \mathrm{U}_{5} \mathrm{U}_{3} \mathrm{U}_{1} \mathrm{I}$. 


\section{Included species}

Pharciceras tridens var. kseirensis Termier \& Termier, 1950, Anti-Atlas; Stenopharciceras progressum Bockwinkel, Becker \& Ebbighausen, 2013, Anti-Atlas; Stenopharciceras protectum Bockwinkel, Becker \& Ebbighausen, 2009, Anti-Atlas; Stenopharciceras lotzi sp. nov., Rhenish Mountains.

Stenopharciceras lotzi sp. nov.

urn:1sid:zoobank.org:act:88748636-7B2F-4BC3-850E-9A42BE35A9DF

Figs 41-42; Tables 25-26

\section{Diagnosis}

Stenopharciceras with thickly discoidal conch at $20 \mathrm{~mm} \mathrm{dm} \mathrm{(ww/} \mathrm{dm} \sim 0.50)$ and thinly discoidal conch at $40 \mathrm{~mm} \mathrm{dm}$ ( $\mathrm{ww} / \mathrm{dm} \sim 0.40$ ); with very narrow to closed umbilicus. Whorl profile slightly compressed (ww/wh $\sim 0.95$ ) at $20 \mathrm{~mm}$ dm and more strongly compressed at $40 \mathrm{~mm} \mathrm{dm} \mathrm{(ww/dm} \sim 0.75$ ); conch widest in the midflank area. Flanks and venter continuously rounded. Outer suture line with bell- or funnel-shaped $\mathrm{E}_{1}$ lobe, parallel-sided, usually pointed, $\mathrm{E}_{2}, \mathrm{~L}$ and $\mathrm{U}_{2}$ lobes separated by rounded saddles. Inner flank and umbilical wall with blunt or rounded $\mathrm{U}_{4}, \mathrm{U}_{6}, \mathrm{U}_{8}$ and $\mathrm{U}_{10}$ lobes.

\section{Etymology}

Named after the geologist Heinrich Lotz (1873-1943), who provided an important collection of fossils from the Red Ironstone.

\section{Material examined}

\section{Holotype}

GERMANY • Rhenish Mountains, Oberscheld (Grube Prinzkessel); late Givetian (Red Ironstone); Lotz 1901 Coll.; MB.C.30254; illustrated in Fig. 41C.

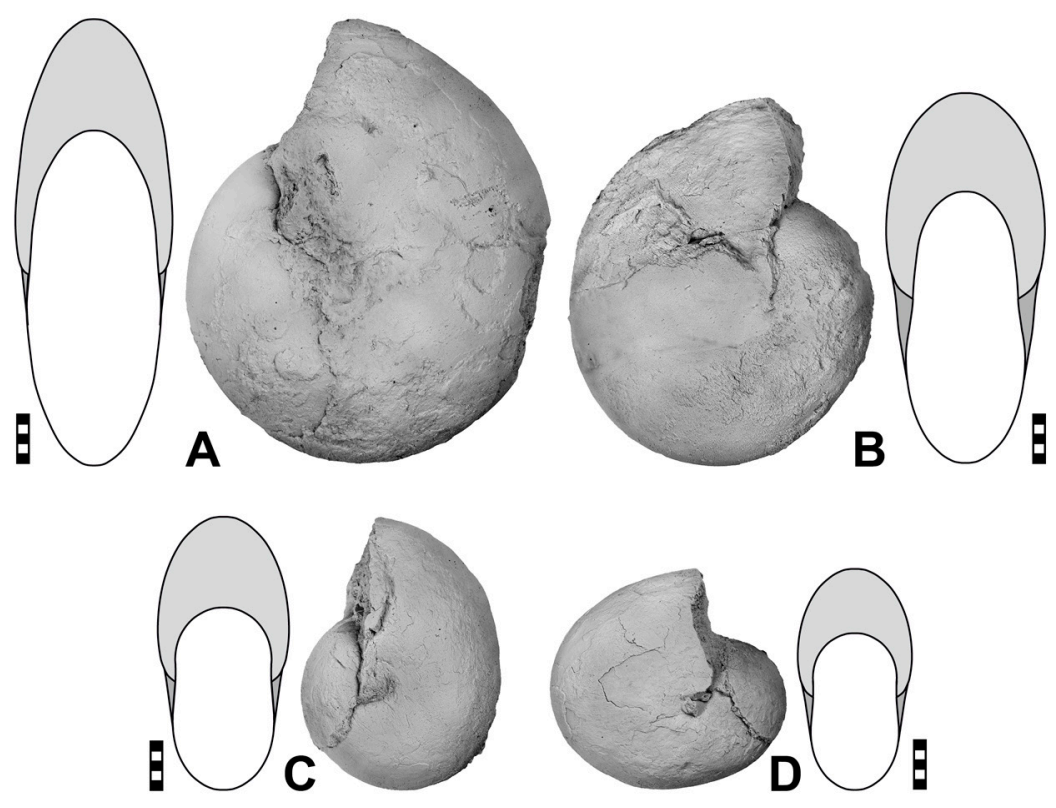

Fig. 41. Stenopharciceras lotzi sp. nov. A. Paratype MB.C.2280 from Oberscheld. B. Paratype MB.C.30255 (Lotz 1902 Coll.) from Oberscheld (Königszug Mine). C. Holotype MB.C.30254 (Lotz 1901 Coll.) from Oberscheld (Prinzkessel Mine). D. Paratype MB.C.30256 (Lotz 1902 Coll.) from Oberscheld (Anna Mine). Scale bar units $=1 \mathrm{~mm}$. 


\section{Paratypes}

GERMANY • 1 specimen; Rhenish Mountains, Oberscheld (Grube Königszug, 90 m Sohle); late Givetian (Red Ironstone); Lotz 1902 Coll.; MB.C.30255 • 1 specimen; Rhenish Mountains, Oberscheld (Grube Prinzkessel); late Givetian (Red Ironstone); Lotz 1901 Coll.; MB.C.30256 3 specimens; Rhenish Mountains, Oberscheld; late Givetian (Red Ironstone); MB.C.2280, MB.C.30257, MB.C.30258.

\section{Description}

Four specimens are selected for description and illustration:

Paratype MB.C.2280: rather well-preserved specimen with nearly $40 \mathrm{~mm}$ conch diameter in haematitic ironstone (Fig. 41A).

Paratype MB.C.30255: deformed specimen with $35 \mathrm{~mm}$ conch diameter in haematitic ironstone (Fig. 41B).

Holotype MB.C.30254: deformed specimen with $27 \mathrm{~mm}$ conch diameter in haematitic ironstone (Fig. 41C).

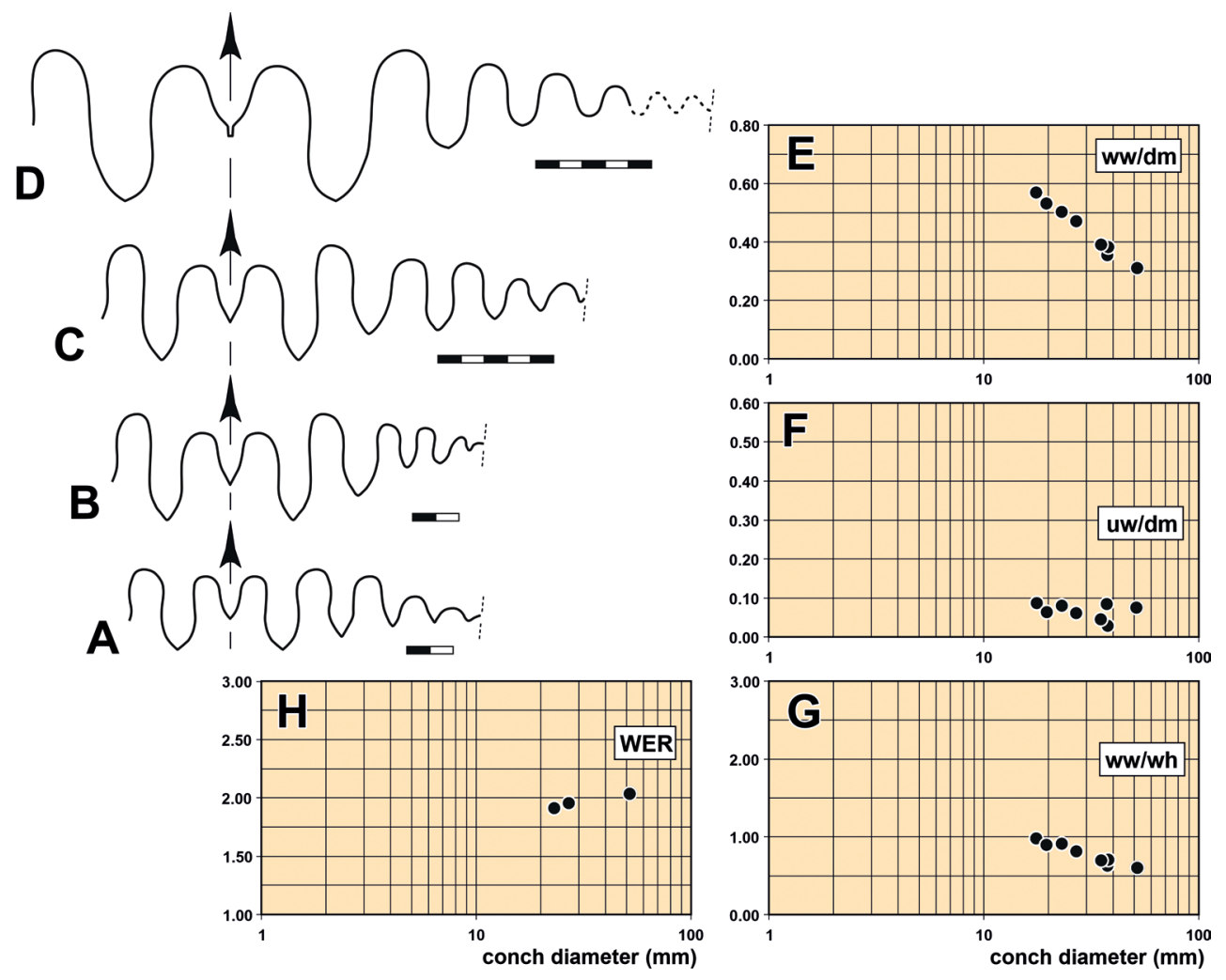

Fig. 42. Stenopharciceras lotzi sp. nov. A. Suture line of holotype MB.C.30254 (Lotz 1901 Coll.) from Oberscheld (Prinzkessel Mine), at $\mathrm{dm}=22.2 \mathrm{~mm}, \mathrm{ww}=9.9 \mathrm{~mm}, \mathrm{wh}=10.6 \mathrm{~mm}$. B. Suture line of paratype MB.C.30256 (Lotz 1901 Coll.) from Oberscheld (Prinzkessel Mine), at $\mathrm{dm}=22.8 \mathrm{~mm}$, $\mathrm{ww}=10.1 \mathrm{~mm}, \mathrm{wh}=11.2 \mathrm{~mm}$. C. Suture line of paratype MB.C. 2280 from Oberscheld, at $w w=12.6 \mathrm{~mm}$, $w h=14.7 \mathrm{~mm}$. D. Suture line of paratype MB.C.30255 (Lotz 1901 Coll.) from Oberscheld (Königszug Mine), at $\mathrm{dm}=35.0 \mathrm{~mm}, \mathrm{ww}=13.5 \mathrm{~mm}, w h=19.5 \mathrm{~mm}$. E-H. Ontogeneric trajectories of the cardinal conch parameters. Abbreviations: see Material and methods. Scale bar units $=1 \mathrm{~mm}$. 
Table 25. Conch dimensions and ratios of selected specimens of Stenopharciceras lotzi sp. nov.

\begin{tabular}{ccccccccccc}
\hline Specimen & $\mathbf{d m}$ & ww & wh & uw & ah & ww/dm & ww/wh & uw/dm & WER & IZR \\
\hline MB.C.2280 & 38.9 & 15.1 & 20.5 & 0.5 & 10.5 & 0.39 & 0.74 & 0.01 & 1.88 & 0.49 \\
MB.C.30255 & 35.2 & 13.7 & 19.5 & 1.5 & - & 0.39 & 0.70 & 0.04 & - & - \\
MB.C.30254 & 27.0 & 12.7 & 15.5 & 1.6 & 7.7 & 0.47 & 0.82 & 0.06 & 1.96 & 0.50 \\
MB.C.30256 & 23.1 & 11.6 & 12.6 & 0.5 & 6.4 & 0.50 & 0.92 & 0.02 & 1.91 & 0.49 \\
\hline
\end{tabular}

Table 26. Conch ontogeny of Stenopharciceras lotzi sp. nov.

\begin{tabular}{cccc}
\hline $\mathbf{d m}$ & conch shape & whorl cross section shape & whorl expansion \\
\hline \multirow{2}{*}{$20 \mathrm{~mm}$} & $\begin{array}{c}\text { thickly discoidal; involute } \\
(\text { ww } / \mathrm{dm} \sim 0.50 ; \text { uw } / \mathrm{dm} \sim 0.02)\end{array}$ & $\begin{array}{c}\text { weakly compressed; very strongly embracing } \\
(\text { ww } / \text { wh } \sim 0.95 ; \text { IZR } \sim 0.50)\end{array}$ & $\begin{array}{c}\text { moderate } \\
(\text { WER } \sim 1.90)\end{array}$ \\
\hline \multirow{2}{*}{$\begin{array}{c}\text { thinly discoidal; involute } \\
\text { mm }\end{array}$} & $\begin{array}{c}\text { weakly compressed; very strongly embracing } \\
(\text { ww } / \mathrm{dm} \sim 0.40 ; \text { uw } / \mathrm{dm} \sim 0.02)\end{array}$ & $\begin{array}{c}\text { moderate } \\
(\text { ww } / \text { wh } \sim 0.75 ; \text { IZR } \sim 0.50)\end{array}$ & $($ WER $\sim 1.90)$ \\
\hline
\end{tabular}

Paratype MB.C.30256: fully chambered, deformed specimen with $23 \mathrm{~mm}$ conch diameter in haematitic ironstone; some parts of the shell preserved (Fig. 41D).

The material allows the study of a rather short ontogentic interval between about 20 and $40 \mathrm{~mm}$ conch diameter. During this interval, the conch becomes slenderer ( $\mathrm{ww} / \mathrm{dm}$ decreases from 0.55 to 0.40 ; ww/wh decreases from 1.00 to 0.70 ). The flanks are convex and the venter is continuously rounded. Specimens MB.C.30254 and MB.C.2280 show a shell ornament with fine, widely spaced growth lines that extend with a lateral sinus and a high, linguiform ventrolateral salient across the flanks.

The suture line of the specimens closely resemble each others. They show that, between 22 and $35 \mathrm{~mm}$ conch diameter, the shape of the external lobe is rather stable, but that this lobe becomes more dominant in its size during ontogeny (Fig. 42A-D). While in holotype MB.C.30254, at $22 \mathrm{~mm}$ conch diameter, the lateral lobe is almost as deep as the external lobe, this proportion has shifted towards a much shorter $\mathrm{L}$ lobe in specimen MB.C.30255 at $35 \mathrm{~mm}$ diameter. The shape of the lateral lobe changes from lanceolate in holotype MB.C.30254 to tongue-shaped in paratype MB.C.30255. The $\mathrm{E}_{1}$ lobe is bell-shaped in MB.C.30255 but V-shaped in the smaller specimens MB.C.30254 or MB.C.2280

\section{Remarks}

Stenopharciceras lotzi $\mathrm{sp}$. nov. superficially resembles Pluripharciceras ahlburgi sp. nov. but possesses a stouter conch (ww/dm $\sim 0.40$ at $35 \mathrm{~mm} \mathrm{dm}$ in contrast to 0.35 in P. ahlburgi sp. nov.). The main differences are in the suture line; $S$. lotzi sp. nov. possesses fewer, rounded lobes on the flank while these lobes are V-shaped in P. ahlburgi sp. nov.

Stenopharciceras lotzi sp. nov. differs from Synpharciceras clavilobum, which it closely resembles in conch shape, in the suture line which is not meandering as in S. clavilobum in the general outline. Furthermore, the $\mathrm{E}_{2}$ lobe is lanceolate and the $\mathrm{L}$ and $\mathrm{U}_{2}$ lobes are usually acute at the base, in contrast to the rounded or blunt lobes in $S$. clavilobum. 
Genus Synpharciceras Schindewolf, 1940

\section{Type species}

Goniatites clavilobus Sandberger \& Sandberger, 1850, by original designation.

\section{Diagnosis}

Synpharciceratinae with thinly pachyconic to thickly discoidal, subevolute to evolute juvenile stage, whorl profile depressed. Adult stage subinvolute to involute with compressed whorl profile; venter rounded. Adult stage with or without ventrolateral grooves. Suture line with wide external lobe, short, funnel-shaped $\mathrm{E}_{1}$ lobe, large, deep lanceolate $\mathrm{E}_{2}$ lobe, smaller lanceolate lateral lobe, and up to 13 outer and inner umbilical lobes. Suture line formula $\left(\mathrm{E}_{2} \mathrm{E}_{1} \mathrm{E}_{2}\right) \mathrm{L} \mathrm{U}_{2} \mathrm{U}_{4} \mathrm{U}_{6} \ldots \mathrm{U}_{12}: \mathrm{U}_{13} \ldots \mathrm{U}_{5} \mathrm{U}_{3} \mathrm{U}_{1} \mathrm{I}$.

\section{Included species}

Goniatites clavilobus Sandberger \& Sandberger, 1850, Rhenish Mountains; Synpharciceras frequens Bockwinkel, Becker \& Ebbighausen, 2013, Anti-Atlas; Synpharciceras spirale Bockwinkel, Becker \& Ebbighausen, 2009, Anti-Atlas; Pharciceras tafilense Termier \& Termier, 1950, Anti-Atlas.

\section{Synpharciceras clavilobum (Sandberger \& Sandberger, 1850)}

Figs 43-45; Table 27

Goniatites clavilobus Sandberger \& Sandberger, 1850: 67, pl. 8 fig. 3.

Prolecanites clavilobus - Frech 1902: 63, pl. 2 fig. 10.

Synpharciceras clavilobum - Kullmann \& Ziegler 1970: 79, pl. 1 figs 6-7, text-figs 2d, 3d. - House in House \& Ziegler 1977: 80, pl. 5 figs 18-19. — Korn \& Klug 2002: 145, text-figs 134j (only).

non Pharciceras clavilobum - Wedekind 1918: 127, pl. 20 figs 4-5, text-fig. 37d.

non Sympharciceras clavilobum - Petter 1959: 147, pl. 7 fig. 15, pl. 8 figs 2-3, 6-8, text-figs 33c, 38. -

Bogoslovsky 1969, pl. 26 fig. 3. - Bensaïd 1974: 115, pl. 5 figs 2, 5, text-fig. 19d. — Korn 1999: text-fig. 2b. - Klug \& Korn 2002: 922, text-fig. 4b. - Korn \& Klug, 2002: 145, text-figs 134c, f, i, 135c. - Bockwinkel et al. 2009: 114, text-figs 26-27, 28d-e; 2013a: 50, text-figs 51-52; 2015: 146, text-figs $27 \mathrm{a}-\mathrm{c}, 28 \mathrm{a}, \mathrm{c}-\mathrm{d} ; 2017: 343$, text-figs 32-33.

\section{Diagnosis}

Synpharciceras with thinly discoidal conch at $30 \mathrm{~mm} \mathrm{dm} \mathrm{(ww/dm} 0.45$ ) with closed umbilicus. Whorl profile slightly compressed (ww/wh $\sim 0.95$ ); conch widest near the umbilicus. Flanks and venter continuously rounded; venter bordered by faint ventrolateral spiral grooves. Outer suture line with weakly pouched, blunt, $\mathrm{E}_{2}, \mathrm{~L}$ and $\mathrm{U}_{2}$ lobes meandering with separating rounded saddles. Inner flank and umbilical wall with blunt $\mathrm{U}_{4}, \mathrm{U}_{6}, \mathrm{U}_{8}^{2}$ and $\mathrm{U}_{10}$ lobes.

\section{Material examined}

\section{Holotype}

GERMANY • Rhenish Mountains, Oberscheld (Grube Königszug); late Givetian (Red Ironstone); 42 (Wiesbaden Museum); illustrated by Sandberger \& Sandberger (1850-1856: pl. 8 fig. 3), House \& Ziegler (1977: pl. 5 figs 18-19) and Bockwinkel et al. (2013a: text-fig. 52e); Wiesbaden Museum nr. 42. (Fig. 43)

\section{Additional material}

GERMANY • 3 specimens; Rhenish Mountains, Oberscheld (Grube Gründchesseite); late Givetian (Red Ironstone); Lotz 1901 Coll.; MB.C.3653, MB.C.30260, MB.C.30261 • 2 specimens; Rhenish Mountains, 
Oberscheld (Grube Anna); late Givetian (Red Ironstone); Koch Coll.; MB.C.22190, MB.C.22191 • 1 specimen; Rhenish Mountains, Oberscheld (Grube Königszug, 60 m Lager); late Givetian (Red Ironstone); Lotz 1902 Coll.; MB.C.30259.

\section{Description}

Holotype 42 in the Wiesbaden Museum is a rather well-preserved, partly exfoliated specimen with $32 \mathrm{~mm}$ diameter, at which the conch dimensions can be obtained at $29 \mathrm{~mm}$ diameter (Fig. 43). It is thinly discoidal ( $\mathrm{ww} / \mathrm{dm}=0.48$ ) with an almost closed umbilicus, but this area is obscured by matrix. The whorl profile is weakly compressed ( $\mathrm{ww} / \mathrm{wh}=0.93)$; it is widest near the umbilicus, from where the convex flanks converge towards the continuously rounded venter. On the venter, there are two weak spiral grooves standing $4 \mathrm{~mm}$ apart. The suture line of the specimen shows a meandering outline with weakly pouched $\mathrm{E}_{2}, \mathrm{~L}$ and $\mathrm{U}_{2}$ lobes similar in outline; they are rounded at the base (Fig. 45A). They are separated by rather narrow, rounded saddles.

MB.C.3653: fully septate specimen with $34 \mathrm{~mm}$ conch diameter in iron-rich micritic limestone, partly filled with sparry calcite (Fig. 44A). It is discoidal ( $\mathrm{ww} / \mathrm{dm}=0.47$ ) with closed umbilicus; the whorl profile is slightly compressed $(\mathrm{ww} / \mathrm{wh}=0.86)$ and the coiling rate is low $(\mathrm{WER}=1.72)$. Shell ornament is not preserved. The specimen is covered by a delicate Runzelschicht, which lines extend with a low ventrolateral projection and a shallow ventral sinus. The outer suture line is rather regularly meandering with elements becoming smaller towards the umbilicus (Fig. 45B). The $\mathrm{E}_{1}$ lobe is funnel-shaped, the lateral prong and the $\mathrm{L}$ and $\mathrm{U}_{2}$ lobes are weakly pouched and blunt, while the $\mathrm{U}_{4}$ and $\mathrm{U}_{6}$ lobes are linguiform.
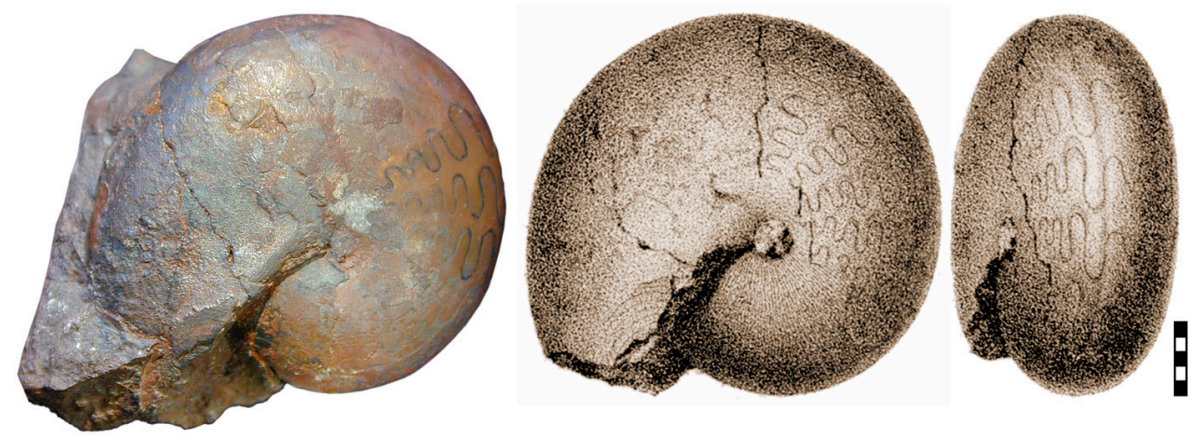

Fig. 43. Synpharciceras clavilobum (Sandberger \& Sandberger, 1850), holotype 42 (Wiesbaden Museum) from Oberscheld, photograph and reproduction of the figure in Sandberger \& Sandberger (1850-1856: pl. 8 figs 3, 3a). Scale bar units $=1 \mathrm{~mm}$.

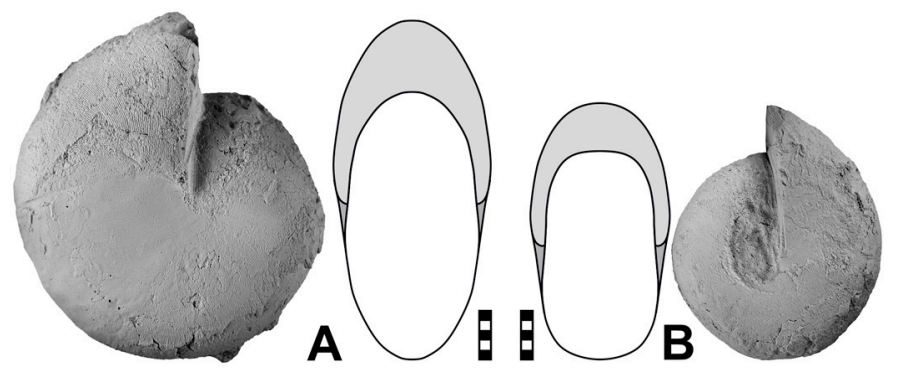

Fig. 44. Synpharciceras clavilobum (Sandberger \& Sandberger, 1850). A. Specimen MB.C.3653 (Lotz 1901 Coll.) from Oberscheld (Gründchesseite Mine). B. Specimen MB.C.22191 (Koch Coll.) from Oberscheld (Anna Mine). Scale bar units $=1 \mathrm{~mm}$. 
Table 27. Conch dimensions and ratios of selected specimens of Synpharciceras clavilobum (Sandberger \& Sandberger, 1850).

\begin{tabular}{ccccccccccc}
\hline Specimen & dm & ww & wh & uw & ah & ww/dm & ww/wh & uw/dm & WER & IZR \\
\hline MB.C.3653 & 33.4 & 15.7 & 18.3 & 0.5 & 7.9 & 0.47 & 0.86 & 0.01 & 1.72 & 0.57 \\
Wiesbaden 42 & 29.0 & 13.9 & 15.0 & 1.4 & - & 0.48 & 0.93 & 0.05 & - & - \\
MB.C.22191 & 25.2 & 13.7 & 13.4 & 1.2 & 6.0 & 0.54 & 1.02 & 0.05 & 1.72 & 0.55 \\
\hline
\end{tabular}

MB.C.22191 is a moderately preserved specimen with $25 \mathrm{~mm}$ conch diameter in haematitic limestone (Fig. 44B).

\section{Remarks}

Synpharciceras clavilobum is a rare species; only a few characteristic specimens are known from the type region. It differs from the more common species Pluripharciceras ahlburgi sp. nov. in the shape of the whorl profile, which in S. clavilobum is widest near the umbilicus but in P. ahlburgi sp. nov. widest in the midflank area. Furthermore, S. clavilobum has a conspicuously meandering suture line, while in P. ahlburgi sp. nov. the lobes are acute.

A species similar in conch shape is Stenopharciceras lotzi sp. nov., but this species differs in the suture line. The general outline of the suture line in that species is not meandering as in S. clavilobum, the $\mathrm{E}_{2}$ lobe is lanceolate and the $\mathrm{L}$ and $\mathrm{U}_{2}$ lobes are usually acute at the base, in contrast to the rounded or blunt lobes in S. clavilobum.

The shape of the whorl profile is also a separating character to distinguish the material from the type region from North African material that has been identified as S. clavilobum (Petter 1959; Bensaïd 1974; Korn \& Klug 2002; Bockwinkel et al. 2009, 2013a, 2015, 2017). As shown in the latter monographic articles, the conch is, in the specimens from the Anti-Atlas, widest in the midflank area, from where
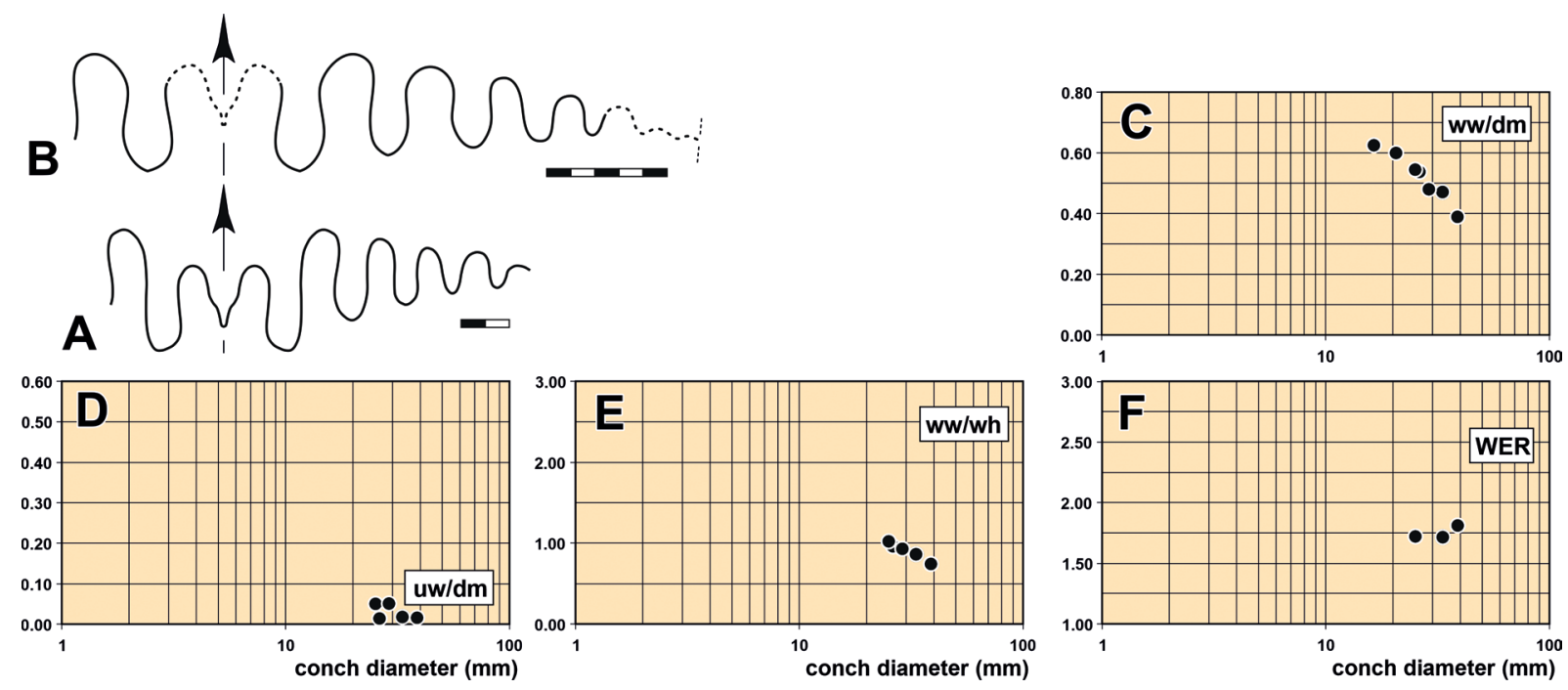

Fig. 45. Synpharciceras clavilobum (Sandberger \& Sandberger, 1850). A. Suture line of holotype 42 (Wiesbaden Museum) from Oberscheld, at $w w=13.8 \mathrm{~mm}$, wh $=14.5 \mathrm{~mm}$. B. Suture line of specimen MB.C.3653 (Lotz 1901 Coll.) from Oberscheld (Gründchesseite Mine), at $\mathrm{dm}=28.3 \mathrm{~mm}$, ww $=15.0 \mathrm{~mm}$, $\mathrm{wh}=16.8 \mathrm{~mm}$. C-F. Ontogeneric trajectories of the cardinal conch parameters. Abbreviations: see Material and methods. Scale bar units $=1 \mathrm{~mm}$. 
the flanks converge towards the umbilicus and the venter. This contrasts with $S$. clavilobum, where it is widest near the umbilicus.

Genus Pluripharciceras Bockwinkel, Becker \& Ebbighausen, 2013

\section{Type species}

Synpharciceras plurilobatum Petter, 1959, by original designation.

\section{Diagnosis}

Synpharciceratinae with discoidal to thinly pachyconic, subevolute juvenile stage, whorl profile depressed. Adult stage subinvolute to involute with compressed whorl profile; WER moderate to high. Flanks and venter continuously rounded, without ventrolateral grooves. $\mathrm{E}_{1}$ lobe funnel or bell-shaped, $\mathrm{E}_{2}$, $\mathrm{L}$ and up to 12 narrow and deep $\mathrm{U}$ lobes, lanceolate or pointed with decreasing size towards the umbilicus.

\section{Included species}

Sympharciceras plurilobatum Petter, 1959, Anti-Atlas; Pluripharciceras orbis Bockwinkel Becker \& Ebbighausen, 2013, Anti-Atlas; Pluripharciceras ahlburgi sp. nov., Rhenish Mountains.

Pluripharciceras ahlburgi sp. nov.

urn:1sid:zoobank.org:act:A582D7F8-2FDE-4A6A-BE12-D45E39487A06

Figs 46-48; Tables 28-29

Pharciceras clavilobum - Wedekind 1918: 127, pl. 20 figs 4-5, text-fig. 37d.

\section{Diagnosis}

Pluripharciceras with thinly discoidal conch at $20 \mathrm{~mm} \mathrm{dm} \mathrm{(ww/dm} \sim 0.40)$ and extremely discoidal conch at $40 \mathrm{~mm} \mathrm{dm} \mathrm{(ww/dm} \sim 0.30)$; with very narrow to closed umbilicus. Whorl profile slightly compressed (ww/wh $\sim 0.90$ ) at $20 \mathrm{~mm} \mathrm{dm}$ and weakly compressed at $40 \mathrm{~mm} \mathrm{dm} \mathrm{(ww/dm} \mathrm{0.60);}$ conch widest in the midflank area. WER moderate to high. Flanks and venter continuously rounded; venter narrowly rounded. Outer suture line with parallel-sided, usually pointed, $E_{2}, L$ and $U_{2}$ lobes meandering with separating saddles. Inner flank and umbilical wall with acute $\mathrm{U}_{4}, \mathrm{U}_{6}, \mathrm{U}_{8}$ and $\mathrm{U}_{10}$ lobes.

\section{Etymology}

Named after Johannes Ahlburg (1883-1919), who assembled a collection of Roteisenstein fossils including the type of the new species.

\section{Material examined}

Holotype

GERMANY • Rhenish Mountains, Oberscheld (Westfeld der Grube Königszug, Firste der 120-150 m Sohle); late Givetian (Red Ironstone); Ahlburg Coll.; MB.C.3644. (Fig. 46B)

\section{Paratypes}

GERMANY • 12 specimens; Rhenish Mountains, Oberscheld (Westfeld der Grube Königszug, Firste der 120-150 m Sohle); late Givetian (Red Ironstone); Ahlburg Coll.; MB.C.3625, MB.C.3632, MB.C.3640, MB.C.3659 to 3661, MB.C.30265.1 to $30265.6-3$ specimens; Rhenish Mountains, Oberscheld; late Givetian (Red Ironstone); Jung 1902, Lotz 1901-1902 Coll.; MB.C.3639, MB.C.22155, MB.C.22188• 1 specimen; Rhenish Mountains, Oberscheld (Tiefe Grube); late Givetian (Red Ironstone); SMF.Mbg.2319 • 1 specimen; Rhenish Mountains, Oberscheld (Tiefe Grube); late Givetian (Red Ironstone); Etzold 1910 Coll.; MB.C.22179 • 1 specimen; Rhenish Mountains, Oberscheld (Grube 
Neuerburg); late Givetian (Red Ironstone); Kauth Coll.; MB.C.30262 • 1 specimen; Rhenish Mountains, Oberscheld (Grube Königszug, 90 m Sohle); late Givetian (Red Ironstone); Teese 1902 Coll.; MB.C.30263 • 2 specimens; Rhenish Mountains, Oberscheld (Grube Königszug, 60 m Sohle); late Givetian (Red Ironstone); Lotz 1901, Jung 1901 Coll.; MB.C.493, MB.C.30264.
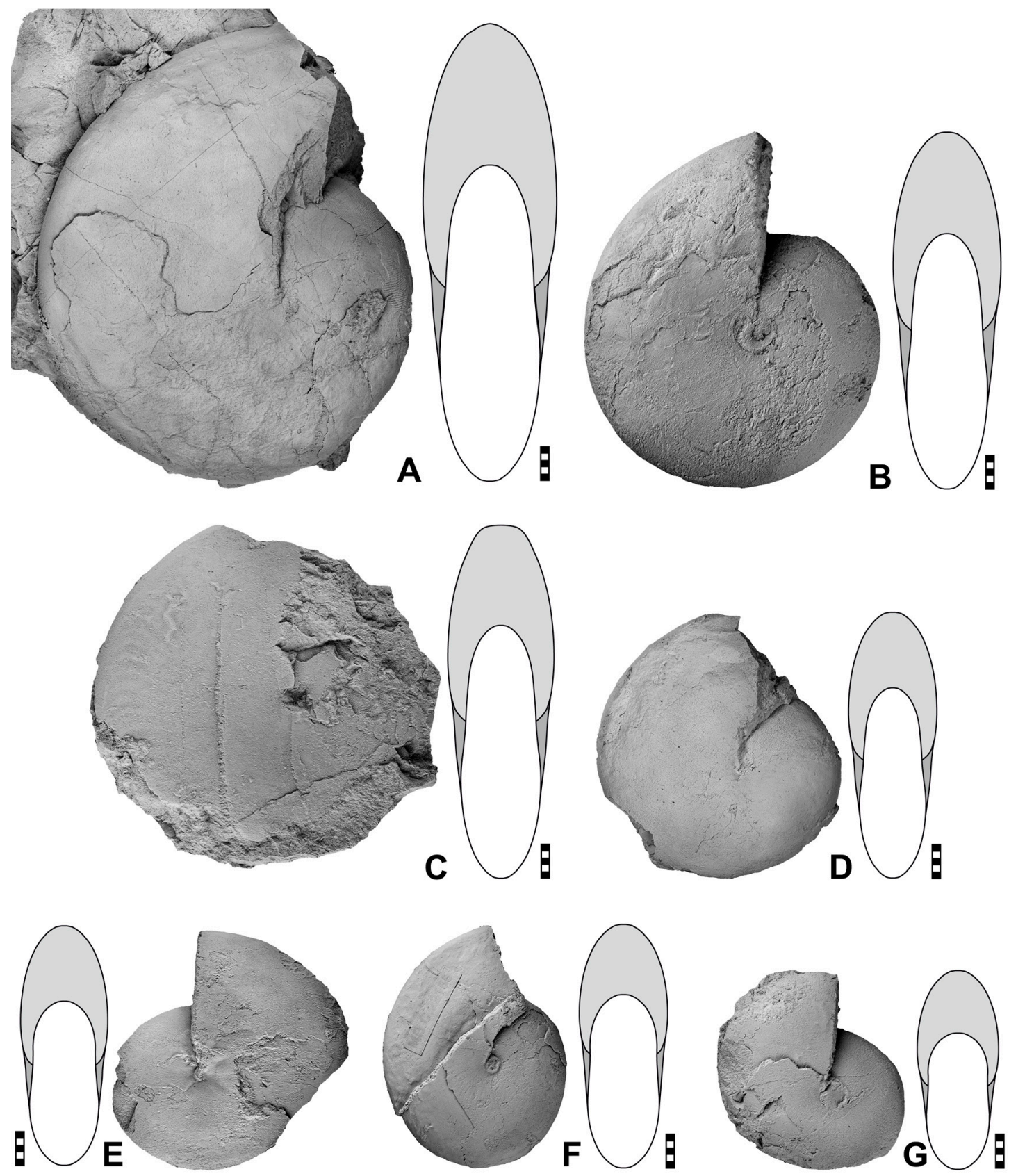

Fig. 46. Pluripharciceras ahlburgi sp. nov. A. Paratype MB.C.493 (Lotz 1901 Coll.) from Oberscheld (Königszug Mine). B. Holotype MB.C.3644 (Ahlburg Coll.) from Oberscheld (Königszug Mine). C. Paratype MB.C.3639 from Oberscheld. D. Paratype MB.C.3640 (Ahlburg Coll.) from Oberscheld (Königszug Mine). E. Paratype MB.C.3659 (Ahlburg Coll.) from Oberscheld (Königszug Mine). F. Paratype MB.C.22155 (Jung 1902 Coll.) from Oberscheld. G. Paratype MB.C.3632 (Ahlburg Coll.) from Oberscheld (Königszug Mine). Scale bar units $=1 \mathrm{~mm}$. 


\section{Description}

Nine specimens are selected for description and illustration:

Paratype SMF.Mbg.2319: rather well-preserved specimen with $75 \mathrm{~mm}$ conch diameter in red ironstone; the specimen was figured by Wedekind (1918, pl. 20. fig. 4) (Fig. 48).

Paratype MB.C.493: rather well-preserved specimen with $35 \mathrm{~mm}$ conch diameter, showing shell ornament, on a block of haematitic ironstone (Fig. 46A).

Holotype MB.C.3644: fairly well-preserved specimen with $52 \mathrm{~mm}$ conch diameter in red ironstone; approximately half of the last preserved volution belongs to the body chamber (Fig. 46B).

Paratype MB.C.3639: steinkern specimen with $51 \mathrm{~mm}$ conch diameter in iron-rich micritic limestone (Fig. 46C).

Paratype MB.C.3640: rather well-preserved specimen with $41 \mathrm{~mm}$ conch diameter in iron-rich micritic limestone (Fig. 46D).

MB.C.3659: deformed but rather well-preserved specimen with $35 \mathrm{~mm}$ conch diameter in iron-rich micritic limestone (Fig. 46E).

Paratype MB.C.22155: laterally deformed specimen with $36 \mathrm{~mm}$ conch diameter in haematitic ironstone (Fig. 46F).

Paratype MB.C.3632: laterally deformed specimen with $29 \mathrm{~mm}$ conch diameter in iron-rich micritic limestone (Fig. 46G).

Paratype MB.C.22179: sectioned specimen with $21 \mathrm{~mm}$ conch diameter in red ironstone (Fig. 47A).

The ontogeny of the principal conch parameters shows triphasic and biphasic trajectories (Fig. 47 D-G). The $\mathrm{ww} / \mathrm{dm}$ trajectory is triphasic with a short early juvenile phase (ww/ dm decreasing from 0.50 at $1 \mathrm{~mm} \mathrm{dm}$ to 0.45 at $2 \mathrm{~mm} \mathrm{dm}$ ), a short second phase (ww/dm increasing from 0.45 at $2 \mathrm{~mm} \mathrm{dm}$ to 0.55 at $8 \mathrm{~mm} \mathrm{dm}$ ) and a longer third phase with decrease of the ww/dm ratio from 0.55 to 0.25 at $75 \mathrm{~mm}$ conch diameter. The uw/dm trajectory has a biphasic course with a short first phase (increase of the $\mathrm{uw} / \mathrm{dm}$ ratio to 0.45 at $3 \mathrm{~mm} \mathrm{dm}$ ) and a second phase with a discontinuous decrease eventually closing the umbilicus.

The whorl profile is crescent-shaped in the juvenile stage up to about $10 \mathrm{~mm}$ conch diameter; thereafter the whorls increase rapidly in height. At the same time, the widest point of the conch migrates from the umbilicus to the midflank area. Specimens larger than $20 \mathrm{~mm}$ show a very shallow umbilical wall. The venter becomes continuously narrower during ontogeny; above $60 \mathrm{~mm}$ conch diameter it is very narrowly rounded or subacute.

Remains of the shell ornament are visible in several specimens. The growth lines are very fine and in paratype MB.C.493, they extend with a moderately deep lateral sinus and a prominent, narrow ventrolateral salient across the flanks. Runzelschicht is preserved in a number of specimens.

In specimen MB.C.3644, some parts of the suture line are visible, showing six acute lobes on the middle and inner flank. 

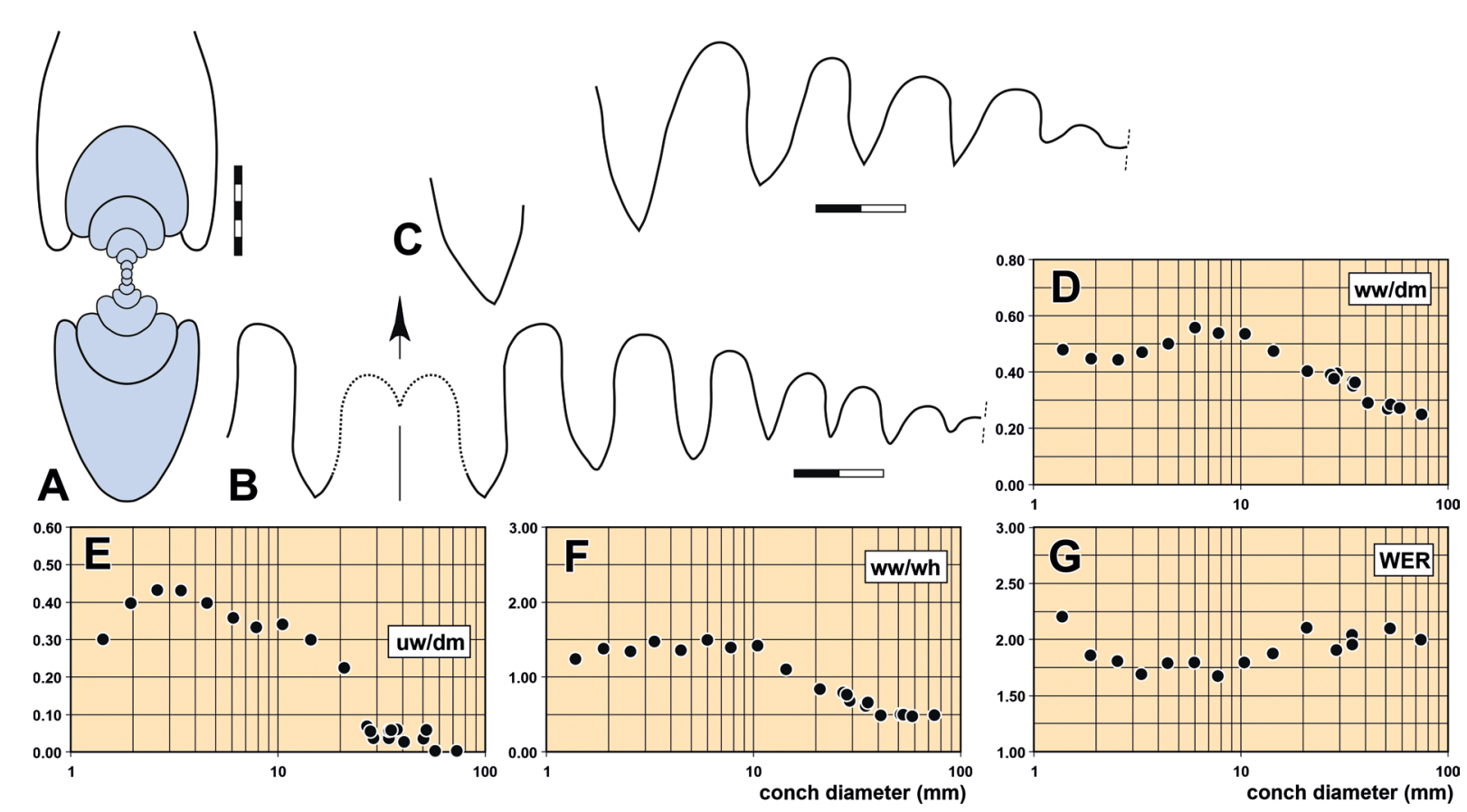

Fig. 47. Pluripharciceras ahlburgi sp. nov. A. Cross section of paratype MB.C.22179 (Etzold 1910 Coll.) from Oberscheld (Tiefe Grube), at $\mathrm{dm}=22.2 \mathrm{~mm}, \mathrm{ww}=9.9 \mathrm{~mm}$, wh $=10.6 \mathrm{~mm}$. B. Suture line of holotype MB.C.3644 (Ahlburg Coll.) from Oberscheld (Königszug Mine), at ww $=10.0 \mathrm{~mm}$, $w h=16.0 \mathrm{~mm}$. C. Suture line of paratype MB.C. 3639 from Oberscheld, at $w w=12.0 \mathrm{~mm}, w h=20.5 \mathrm{~mm}$. D-G. Ontogeneric trajectories of the cardinal conch parameters. Abbreviations: see Material and methods. Scale bar units $=1 \mathrm{~mm}$.

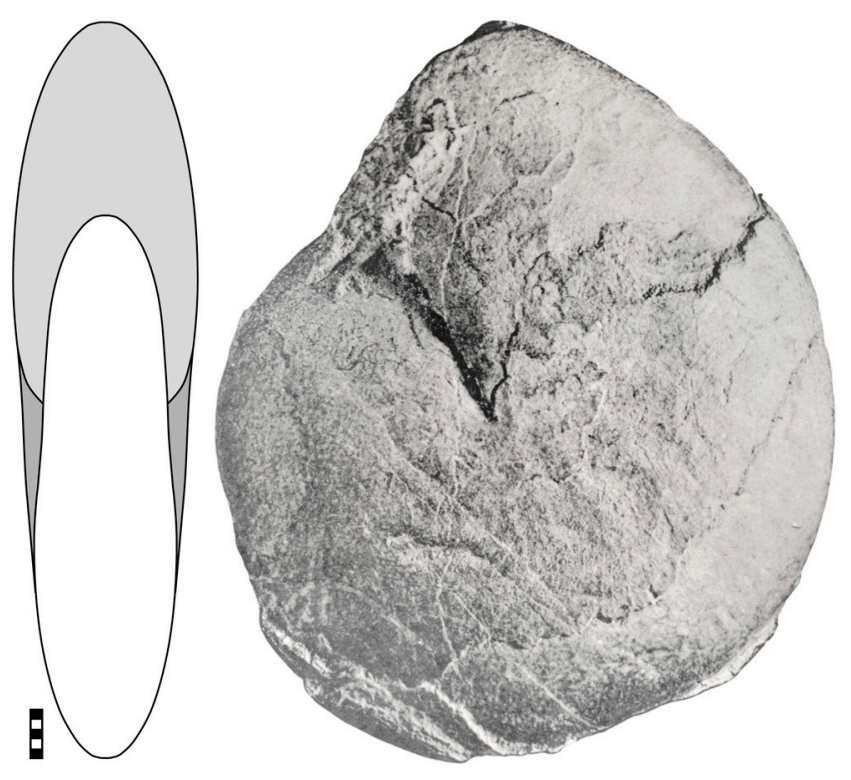

Fig. 48. Pluripharciceras ahlburgi sp. nov, paratype SMF.Mbg.2319 from Oberscheld (Tiefe Grube), reproduction from Wedekind (1918: pl. 20 fig. 4). Scale bar units $=1 \mathrm{~mm}$. 
Table 28. Conch dimensions and ratios of selected specimens of Pluripharciceras ahlburgi sp. nov.

\begin{tabular}{ccccccccccc}
\hline Specimen & dm & ww & wh & uw & ah & ww/dm & ww/wh & uw/dm & WER & IZR \\
\hline SMF.Mbg.2319 & 74.7 & 18.5 & 38.7 & 0.0 & 22.0 & 0.25 & 0.48 & 0.00 & 2.01 & 0.43 \\
MB.C.493 & 66.8 & 19.5 & 38.8 & 0.0 & 18.2 & 0.29 & 0.50 & 0.00 & 1.89 & 0.53 \\
MB.C.22176 & 53.0 & 15.0 & 31.0 & 3.0 & 16.5 & 0.28 & 0.48 & 0.06 & 2.11 & 0.47 \\
MB.C.3644 & 51.8 & 16.0 & 26.5 & 3.8 & 15.5 & 0.31 & 0.60 & 0.07 & 2.04 & 0.42 \\
MB.C.3640 & 41.2 & 11.9 & 25.0 & 1.0 & - & 0.29 & 0.48 & 0.02 & - & - \\
MB.C.22155 & 34.9 & 12.2 & 20.2 & 1.9 & 10.0 & 0.35 & 0.60 & 0.05 & 1.96 & 0.50 \\
MB.C.3659 & 34.8 & 12.7 & 20.0 & 0.0 & 10.5 & 0.36 & 0.64 & 0.00 & 2.05 & 0.48 \\
MB.C.3632 & 29.2 & 11.5 & 17.1 & 0.0 & 8.1 & 0.39 & 0.67 & 0.00 & 1.92 & 0.53 \\
\hline
\end{tabular}

Table 29. Conch ontogeny of Pluripharciceras ahlburgi sp. nov.

\begin{tabular}{|c|c|c|c|}
\hline dm & conch shape & whorl cross section shape & whorl expansion \\
\hline $5 \mathrm{~mm}$ & $\begin{array}{l}\text { thickly discoidal; subevolute } \\
\text { (ww/dm } \sim 0.50 ; \mathrm{uw} / \mathrm{dm} \sim 040 \text { ) }\end{array}$ & $\begin{array}{l}\text { weakly depressed; strongly embracing } \\
\quad(\mathrm{ww} / \mathrm{wh} \sim 1.40 ; \text { IZR } \sim 0.30 \text { ) }\end{array}$ & $\begin{array}{c}\text { moderate } \\
(\mathrm{WER} \sim 1.80)\end{array}$ \\
\hline $10 \mathrm{~mm}$ & $\begin{array}{l}\text { thickly discoidal; subevolute } \\
\text { (ww/dm } \sim 0.55 ; \mathrm{uw} / \mathrm{dm} \sim 0.35 \text { ) }\end{array}$ & $\begin{array}{l}\text { weakly depressed; strongly embracing } \\
\quad(\mathrm{ww} / \mathrm{wh} \sim 1.40 ; \text { IZR } \sim 0.30)\end{array}$ & $\begin{array}{c}\text { moderate } \\
(\mathrm{WER} \sim 1.80)\end{array}$ \\
\hline $20 \mathrm{~mm}$ & $\begin{array}{l}\text { thinly discoidal; subinvolute } \\
\text { (ww/dm } \sim 0.40 ; \mathrm{uw} / \mathrm{dm} \sim 0.20 \text { ) }\end{array}$ & $\begin{array}{l}\text { weakly compressed; strongly embracing } \\
\text { (ww/wh } \sim 0.85 ; \text { IZR } \sim 0.35 \text { ) }\end{array}$ & $\begin{array}{l}\text { moderate to high } \\
(\mathrm{WER}=1.95-2.05)\end{array}$ \\
\hline $40 \mathrm{~mm}$ & $\begin{array}{l}\text { extremely discoidal; involute } \\
\text { (ww/dm } \sim 0.30 ; \mathrm{uw} / \mathrm{dm} \sim 0.05 \text { ) }\end{array}$ & $\begin{array}{l}\text { weakly compressed; very strongly embracing } \\
\text { (ww/wh } \sim 0.55 ; \mathrm{IZR} \sim 0.50 \text { ) }\end{array}$ & $\begin{array}{l}\text { moderate to high } \\
(\mathrm{WER}=1.95-2.05)\end{array}$ \\
\hline
\end{tabular}

\section{Remarks}

Pluripharciceras ahlburgi sp. nov. differs from Synpharciceras clavilobum in the shape of the whorl profile, which in P. ahlburgi sp. nov. is widest in the midflank area but in S. clavilobum is widest near the umbilicus. Furthermore, S. clavilobum has a conspicuously meandering suture line, while in P. ahlburgi sp. nov. the lobes are V-shaped and acute.

Pluripharciceras ahlburgi sp. nov. resembles Stenopharciceras lotzi sp. nov. but possesses a slenderer conch (ww $/ \mathrm{dm} \sim 0.35$ at $35 \mathrm{~mm}$ dm in contrast to 0.40 in $S$. lotzi sp. nov.). Furthermore, S. lotzi sp. nov. possesses fewer, rounded lobes on the flank while these lobes are V-shaped in P. ahlburgi sp. nov.

Superfamiliy Triainoceratoidea Hyatt, 1884

Family Triainoceratidae Hyatt, 1884

For a definition of the family and the included genera, see Korn \& Klug (2002: 146).

\section{Genus Sandbergeroceras Hyatt, 1884}

\section{Type species}

Goniatites tuberculoso-costatus Sandberger \& Sandberger, 1850, by original designation.

\section{Diagnosis}

Triainoceratidae with eight to twelve umbilical lobes. 


\section{Included species}

Goniatites tuberculoso-costatus Sandberger \& Sandberger, 1850, Rhenish Mountains; Sandbergeroceras acutum Termier \& Termier, 1950, Anti-Atlas; Goniatites costatus d'Archiac \& de Verneuil, 1842, Rhenish Mountains; Sandbergeroceras sandbergerorum Miller, 1938, Rhenish Mountains; Sandbergeroceras syngonum Clarke, 1899, New York; Goniatites incertus d'Archiac \& de Verneuil, 1842, Rhenish Mountains; Goniatites tuberculosus d'Archiac \& de Verneuil, 1842, Rhenish Mountains; Sandbergeroceras archiaci sp. nov., Rhenish Mountains.

\section{Remarks}

Hyatt (1883-1884) established two genera for multilobate, coarsely ribbed ammonoids previously described from the Red Ironstone by d'Archiac \& de Verneuil (1842) and Sandberger \& Sandberger (1850-1856):

(1) "Sandbergeoceras", which was probably misspelled by Hyatt (1883-1884: 333); his intention was obviously the genus name Sandbergeroceras with "Goniatites tuberculoso-costatus Sandberger \& Sandberger, 1850" as type species. This species, however, was not without problems, as it was only conceived by Sandberger \& Sandberger (1850-1856) as a combination of the two species "Goniatites tuberculosus" and "Goniatites costatus" introduced by d'Archiac \& de Verneuil (1842). Miller (1938) discussed these problems and created the new name Sandbergeroceras sandbergerorum to replace "Goniatites tuberculoso-costatus", but later(Miller 1952) supported the use of the name Sandbergeroceras tuberculosocostatum. This name was subsequently confirmed by the International Commission of Zoological Nomenclature (1956). Hyatt (1883-1884) characterised the genus Sandbergeroceras on the basis of the suture line illustrated by Sandberger \& Sandberger (1850-1856: pl. 4 fig. 1f), which shows an undivided external lobe. However, it should be noted that the external lobe of the illustrated small specimen (Sandberger \& Sandberger 1850-1856: pl. 4 fig. 1a-e) is already rather clearly divided.

(2) Triainoceras, which was introduced by Hyatt(1883-1884:336) with "Goniatites costatus d'Archiac \& de Verneuil, 1842" as the type species. This genus should be separated from "Sandbergeoceras" only in the trident subdivision of the external lobe.

Both genera are probably to be regarded as synonyms; it is to be considered which of the two can be considered more suitable for classifing the specimens from the Red Ironstone. Since better original material is available for "Goniatites tuberculoso-costatus Sandberger \& Sandberger, 1850", the genus Sandbergeroceras, which is founded on this species is preferred here.

Sandbergeroceras tuberculosocostatum (Sandberger \& Sandberger, 1850) Figs 49, 50C, 51B, 52; Table 30

Goniatites tuberculoso-costatus Sandberger \& Sandberger, 1850: 64, pl. 4 fig. 1. Sandbergeroceras sandbergerorum Miller, 1938: 178, text-fig. 38a.

Sandbergeoceras tuberculoso-costatum - Hyatt 1884: 333.

Sandbergeroceras tuberculoso-costatum - Foord \& Crick 1897: 244, text-fig. 155a-f.

Triaenoceras costatum - Drevermann 1903: 85, pl. 5 figs 1-5.

Sandbergeroceras tuberculosocostatum - Bogoslovsky 1969: 278, text-fig. $92 \mathrm{~b}$.

Sandbergeroceras sandbergerorum - House \& Ziegler 1977: pl. 6 figs 16-18.

Triainoceras tuberculosocostatum - Korn \& Klug 2002: 148, text-fig. 137g.

non Goniatites tuberculoso-costatus - Tietze 1869: 38; 1871: 130, pl. 16 fig. 6. 


\section{Diagnosis}

Species of Sandbergeroceras with thinly discoidal, subevolute conch at $30 \mathrm{~mm} \mathrm{dm} \mathrm{(ww/} \mathrm{dm} \sim 0.35$; $\mathrm{uw} / \mathrm{dm} \sim 0.40$ ). Whorl profile weakly depressed ( $\mathrm{ww} / \mathrm{wh} \sim 1.10$ ); venter narrowly rounded. Venter becoming subacute at about $40 \mathrm{~mm} \mathrm{dm}$. Two shallow spiral grooves on the venter. Shell ornament with 30 almost linear, sharp ribs on the flanks and coarse growth lines.

\section{Material examined}

Lectotype (designated here)

GERMANY - Rhenish Mountains, Oberscheld; early Frasnian (Red Ironstone); 28 (Wiesbaden Museum); illustrated by Sandberger \& Sandberger (1850-1856: pl. 4 fig. 1) and House \& Ziegler (1977: pl. 6 figs 16-18); Wiesbaden Museum nr. 28. (Fig. 49A)

Most probably, the illustration of a smaller individual (Sandberger \& Sandberger 1850-1856: pl. 4 fig. $1 \mathrm{a}-\mathrm{f}$ ) is from the inner whorls of the same specimen.

\section{Additional material}

GERMANY - 1 specimen; Rhenish Mountains, Oberscheld; early Frasnian (Red Ironstone); SMF.Mbg.6360 - 1 specimen; Rhenish Mountains, Oberscheld; early Frasnian (Red Ironstone); Wiesbaden Museum nr. 41.

\section{Description}

Lectotype 28 is an incomplete specimen, without shell remains, with an original conch diameter of more than $70 \mathrm{~mm}$ in iron-rich limestone (Fig. 49A). The outer whorl is crushed but the inner whorls are rather

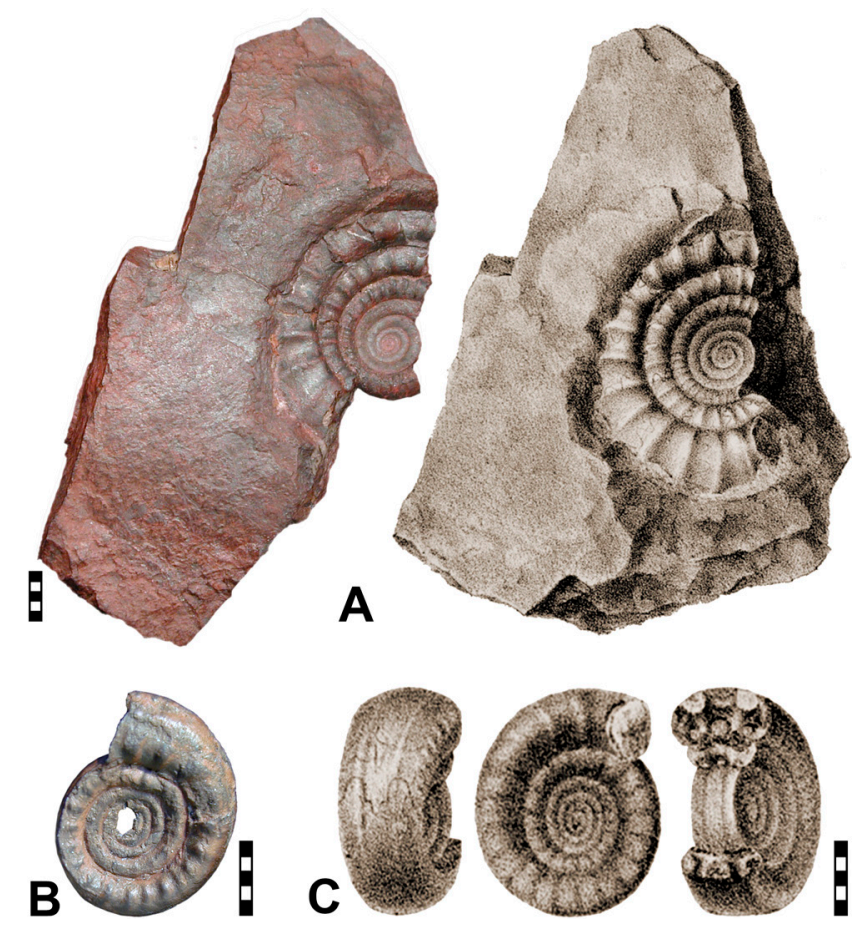

Fig. 49. Sandbergeroceras tuberculosocostatum (Sandberger\& Sandberger, 1850). A. Lectotype specimen 28 (Wiesbaden Museum) from Oberscheld; photograph and reproduction of the figure in Sandberger \& Sandberger (1850-1856: pl. 4 fig. 1). B. Specimen 41 (Wiesbaden Museum) from Oberscheld; specimen of the figure in Sandberger \& Sandberger (1850-1856: pl. 8 fig. 2). C. Reproduction of the figure in Sandberger \& Sandberger (1850-1856: pl. 4 fig. 1a-c). Scale bar units $=1 \mathrm{~mm}$. 
well-preserved. It allows an insight into the conch ontogeny from the initial stage to the adult stage. Up to about $18 \mathrm{~mm}$ diameter, the conch is very evolute; thereafter, the whorl begins to grow in height and the relative width of the umbilicus decreases. At $15 \mathrm{~mm}$ diameter, the whorls are broadly kidney-shaped in profile and the venter is broadly rounded. At about $30 \mathrm{~mm}$ diameter the whorls are already much higher and at about $45-50 \mathrm{~mm}$ diameter apparently already compressed-triangular with a very narrow venter. The inner whorls are apparently unsculptured, but at about $10 \mathrm{~mm}$ diameter sharp, initially closely spaced ribs appear; at about $12 \mathrm{~mm}$ diameter there are about eight ribs on a quarter whorl. The ribs are present up to a conch diameter of $30 \mathrm{~mm}$; they run almost straight across the flank.

SMF.Mbg.6360: incomplete, slightly distorted specimen of about $75 \mathrm{~mm}$ conch diameter in iron-rich limestone with shell remains preserved (Fig. 50C). It is a specimen showing the transition from the preadult to the adult stage. It has a diameter of about $75 \mathrm{~mm}$; at this stage the conch has the shape of a lens ( $\mathrm{ww} / \mathrm{dm} \sim 0.25, \mathrm{uw} / \mathrm{dm} \sim 0.30$ ). The whorl profile is compressed triangular with subacute venter, the coiling rate is very high (WER 2.45). Almost the entire last whorl is sculptureless; only at the beginning a few folds are visible on the inner half of the flank. Two inner whorls can be partially studied
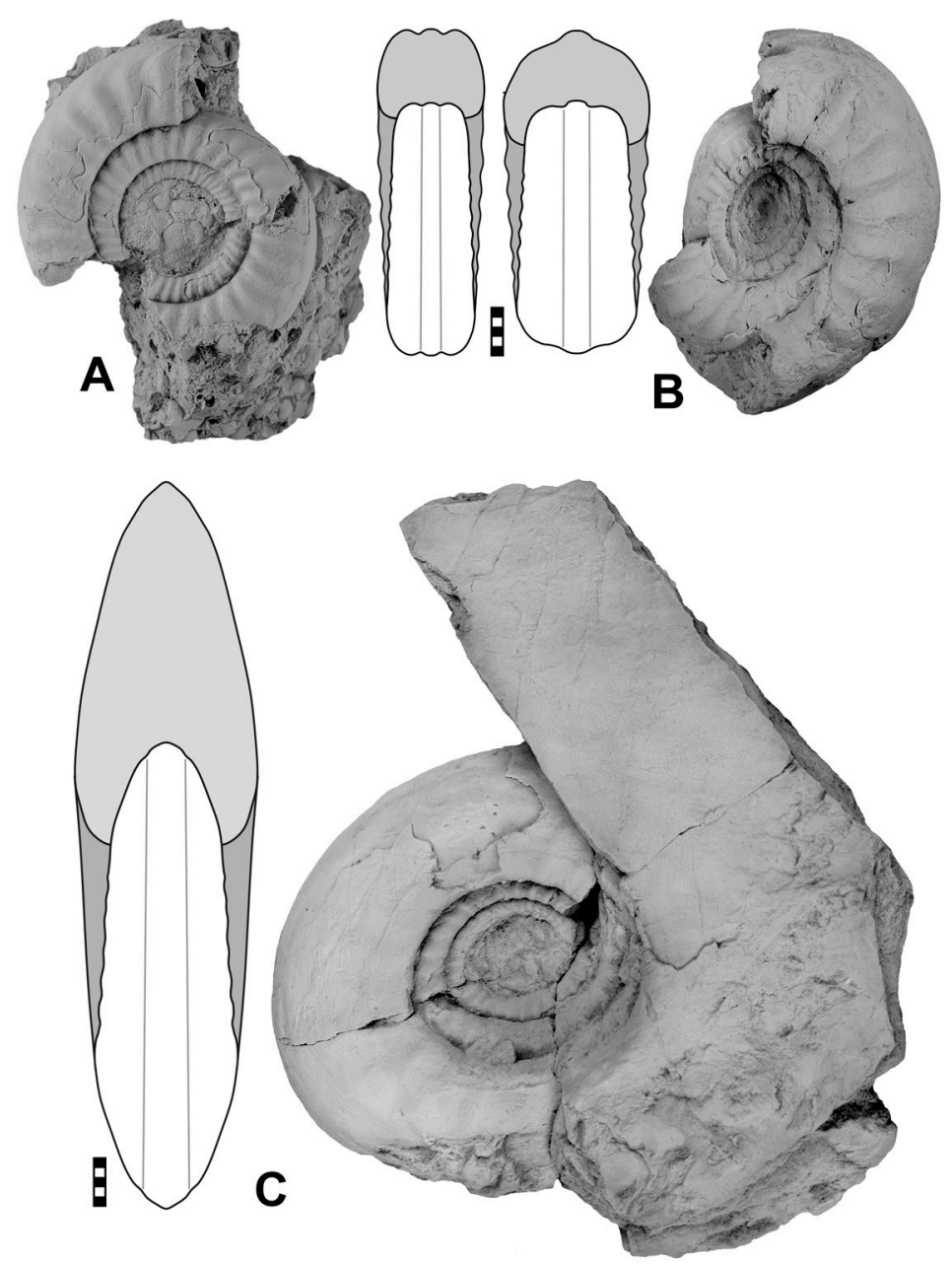

Fig. 50. A. Sandbergeroceras archiaci sp. nov., holotype MB.C.3671 (Koch Coll.) from Oberscheld (Anna Mine). B. Sandbergeroceras costatum (d'Archiac \& de Verneuil, 1842), neotype MB.C.7695 (Erbreich Coll.) from Dillenburg. C. Sandbergeroceras tuberculosocostatum (Sandberger \& Sandberger, 1850), specimen SMF.Mbg.6360 from Oberscheld. Scale bar units $=1 \mathrm{~mm}$. 
in the umbilicus. They show that the conch is evolute and coarsely ribbed. There are about 30 sharp ribs per whorl.

The suture line shows, at a whorl height of $15.5 \mathrm{~mm}$, a Y-shaped, divided external lobe with very narrow, ventrally somewhat pouched prongs and a median saddle reaching half the height of the lobe (Fig. 51B). The ventrolateral saddle is rounded and slightly tilted in the dorsal direction. The lateral lobes are deep and inflated, with a mammiform base. Two more, V-shaped and much smaller umbilical lobes follow on the flank. On the inner flanks and the umbilical wall no portion of the suture line is preserved, but it is likely that more lobes would follow.

\section{Remarks}

With the decision of the International Commission of Zoological Nomenclature (1956), at the request of Miller (1952), the species Sandbergeroceras sandbergerorum was declared an objective synonym of S. tuberculosocostatum. This decision was apparently unknown to House (in House \& Ziegler 1977), so that he considered $S$. sandbergerorum valid and designated the Wiesbaden specimen as lectotype. This specimen is determined here as the lectotype of $S$. tuberculosocostatum.

The suture line shown here significantly differs from the illustration of Sandberger \& Sandberger (1850 1856: pl. 4 fig. 1f), which had been copied several times (Foord \& Crick 1897; Miller 1938; Bogoslovsky 1969; Korn \& Klug 2002). The reason for this difference could be that the latter specimen has been cut too deeply and therefore some features have been lost; the illustrations of specimens as well as suture lines are usually excellent and very accurate in this monograph. The suture line shown here (Fig. 51B) is similar to the one published by Bogoslovsky (1969) for "Triainoceras gerassimovi". However, that species has only two lobes on the flank, the somewhat pouched, V-shaped lateral lobe and a somewhat smaller, V-shaped umbilical lobe. Because of this somewhat simpler suture line with fewer elements, the species became the type species of Altayites (Korn \& Klug 2002).

Although the material is incomplete and not well preserved, the species can be reasonably well defined. One problem, however, could be that the specimens do not belong to the same species.

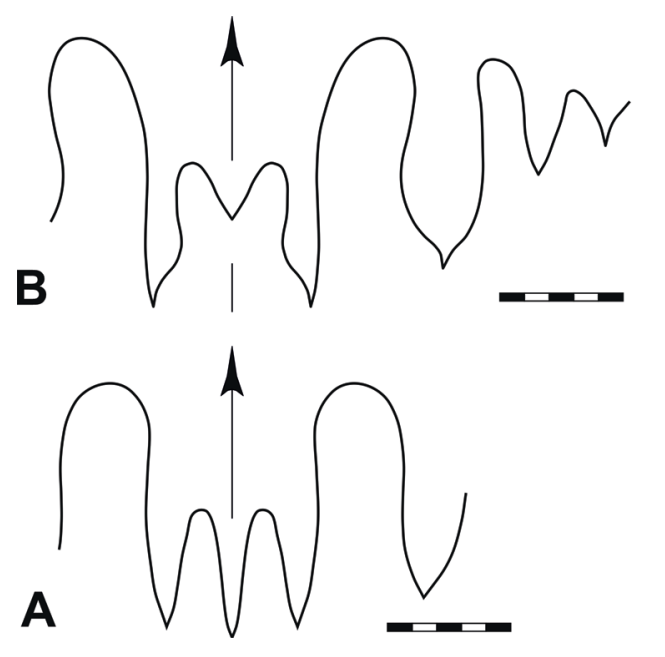

Fig. 51. A. Sandbergeroceras costatum (d'Archiac \& de Verneuil, 1842), suture line of neotype MB.C. 7695 from Dillenburg, at $w w=15.7 \mathrm{~mm}, \mathrm{wh}=12.7 \mathrm{~mm}$. B. Sandbergeroceras tuberculosocostatum (Sandberger \& Sandberger, 1850), suture line of specimen SMF.Mbg.6360 from Oberscheld, at $\mathrm{ww}=13.5 \mathrm{~mm}, \mathrm{wh}=15.5 \mathrm{~mm}$. Abbreviations: see Material and methods. Scale bar units $=1 \mathrm{~mm}$. 
Table 30. Conch dimensions and ratios of selected specimens of Sandbergeroceras tuberculosocostatum (Sandberger \& Sandberger, 1850).

\begin{tabular}{ccccccccccc}
\hline Specimen & dm & ww & wh & uw & ah & ww/dm & ww/wh & uw/dm & WER & IZR \\
\hline SMF.Mbg.6360 & 74.8 & 18.8 & 37.2 & 22.6 & 26.8 & 0.25 & 0.51 & 0.30 & 2.43 & 0.28 \\
SMF.Mbg.6360 & 46.5 & 15.1 & 14.2 & 17.8 & - & 0.32 & 1.06 & 0.38 & - & - \\
\hline
\end{tabular}

Sandbergeroceras tuberculosocostatum differs from S. costatum in the form of the whorl profile. This is much slenderer in $S$. tuberculosocostatum (ww/wh $\sim 1.10$ in comparison to $\sim 1.30$ in $S$. costatum). Furthermore, the whorl profile begins to flatten with a subacute venter already at about $30 \mathrm{~mm}$ conch diameter in S. tuberculosocostatum, while the venter is still rounded in S. costatum.

The main difference to $S$. archiaci sp. nov. is that the ventrolateral grooves are less pronounced in S. tuberculosocostatum. The umbilicus is, at a comparable diameter, narrower in S. tuberculosocostatum (ww/ dm $\sim 0.40$ in S. tuberculosocostatum but $\sim 0.50$ in $S$. archiaci sp. nov.).

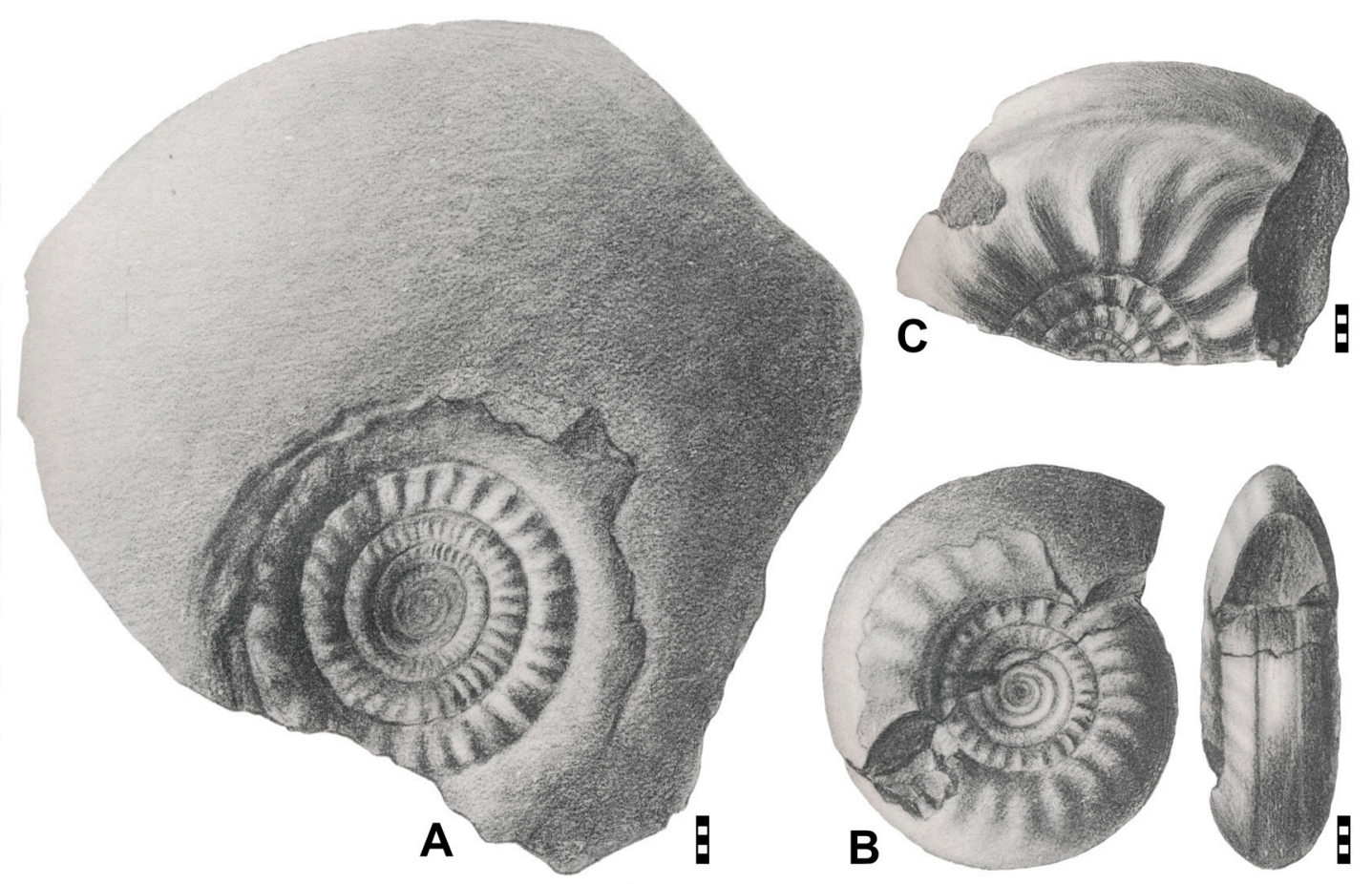

Fig. 52. Sandbergeroceras tuberculosocostatum (Sandberger \& Sandberger, 1850), reproductions of illustrations in Drevermann (1903). Scale bar units $=1 \mathrm{~mm}$.

Sandbergeroceras costatum (d'Archiac \& de Verneuil, 1842)

Figs 50B, 51A, 53A; Table 31

Goniatites costatus d'Archiac \& de Verneuil, 1842: 340, pl. 31 fig. 1, 1 a.

Triainoceras costatum - Hyatt 1884: 336. - Korn \& Klug 2002: 148, text-fig. 137h.

Sandbergeroceras costatum - Schindewolf 1940: 434, pl. 1 figs 4-5, text-fig. 32. 
non Triainoceras costatum - Frech 1897: 177e, fig. 1b, e; 1902: 62, fig. 20c. — Belka et al. 1999: pl. 5

figs 1-2. - Korn \& Klug 2002: 148, text-fig. 137d, f.

non Triaenoceras costatum - Drevermann 1903: 85, pl. 5 figs 1-5.

non Sandbergeroceras costatum - Termier \& Termier 1950: 54, pl. 150 figs 52-54.

non Pharciceras (Sandbergeroceras) costatum - Petter 1959: 144, pl. 8 fig. 13, 13a, text-fig. 33g, 1.

\section{Diagnosis}

Species of Sandbergeroceras with discoidal, evolute conch at $30 \mathrm{~mm} \mathrm{dm}$ (ww/dm $\sim 0.45 ; \mathrm{uw} / \mathrm{dm}$ $\sim 0.40$ ). Whorl profile weakly depressed (ww/wh $\sim 1.30$ ); venter narrowly rounded. Two moderately deep spiral grooves on the venter. Shell ornament with 30 sigmoidal, sharp ribs on the flanks and coarse growth lines.

\section{Material examined}

Neotype (here designated)

GERMANY - Rhenish Mountains, Dillenburg; early Frasnian (Red Ironstone); Erbreich Coll.; MB.C.7695. (Fig. 50B)

\section{Remarks to the type material}

The whereabouts of the original material is not known. The specimen illustrated by d'Archiac \& de Verneuil (1842: pl. 36 fig. 1) does not exist in the de Verneuil collection at the University of Lyon, where other original specimens of this work are located (Emmanuel Robert, written comm., April $8^{\text {th }}$, 2021). However, the description and illustration by d'Archiac \& de Verneuil (1842) allows the species to be characterised (Fig. 53). The only available specimen MB.C.7695 corresponds well with the one illustrated by d'Archiac \& de Verneuil (1842), in conch form as well as sculpture and suture line. It can therefore, with little doubt, be considered conspecific. It is herewith proposed as the neotype of the species.

\section{Description}

MB.C.7695: incomplete, somewhat distorted specimen of about $42 \mathrm{~mm}$ conch diameter in iron-rich limestone (Fig. 50B). Although somewhat deformed laterally, it allows the study of conch geometry and ontogenetic development. At $33 \mathrm{~mm}$ diameter, the conch is discoidal and subevolute (ww/ $\mathrm{dm} \sim 0.45$, $\mathrm{uw} / \mathrm{dm} \sim 0.40$ ) with a broad pear-shaped whorl profile ( $\mathrm{ww} / \mathrm{wh} \sim 1.30$ ), which is widest in the middle of the flanks. The umbilical edge is rounded; the external side has a rounded keel accompanied by
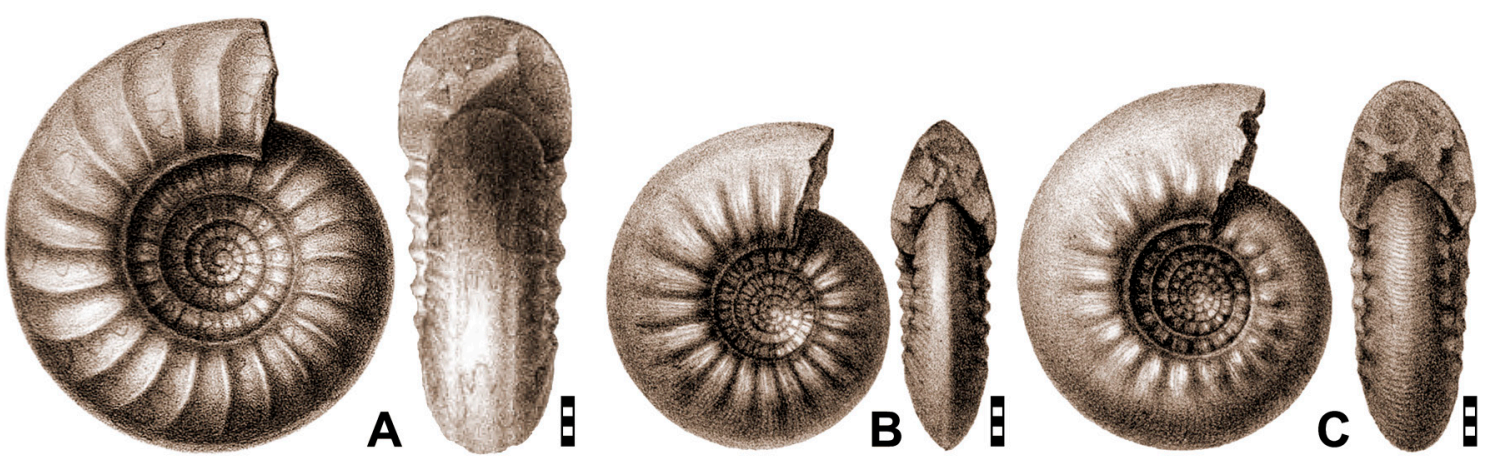

Fig. 53. Triainoceratidae from the Red Ironstone Formation, all reproduced from d'Archiac \& de Verneuil (1842). A. Sandbergeroceras costatum (d'Archiac \& de Verneuil, 1842). B. Sandbergeroceras incertum (d'Archiac \& de Verneuil, 1842). C. Sandbergeroceras tuberculosum (d'Archiac \& de Verneuil, 1842). Scale bar units $=1 \mathrm{~mm}$. 
Table 31. Conch dimensions and ratios of selected specimen of Sandbergeroceras costatum (d'Archiac \& de Verneuil, 1842).

\begin{tabular}{ccccccccccc}
\hline Specimen & $\mathbf{d m}$ & ww & wh & uw & ah & ww/dm & ww/wh & uw/dm & WER & IZR \\
\hline MB.C.7695 & 33.2 & 15.1 & 11.7 & 13.5 & 7.3 & 0.45 & 1.29 & 0.41 & 1.64 & 0.38 \\
\hline
\end{tabular}

shallow longitudinal grooves. The interior whorls are poorly preserved and do not allow any study of the ornament. The last one and one-half whorls possess sharp ribs, which initially extend with a concave curve, then straight and finally with a slightly convex curve over the flank. The penultimate whorl shows sharp growth lines with the same course as the ribs.

Only a short portion of the suture line is visible in the ventral area. The external lobe is parallel-sided with a median saddle that reaches about half the height of the lobe. The $\mathrm{E}_{1}$ lobe is very narrow and very deep (Fig.51A).

\section{Remarks}

Sandbergeroceras costatum differs from S. tuberculosocostatum in the form of the whorl profile, which is much stouter in $S$. costatum (ww/wh $\sim 1.30$ in comparison to $\sim 1.10$ in $S$. tuberculosocostatum). The whorl profile begins to flatten with a subacute venter already at about $30 \mathrm{~mm}$ conch diameter in S. tuberculosocostatum, while the venter is still rounded at this diameter in S. costatum.

The main difference to $S$. archiaci sp. nov. is that the ventrolateral grooves are less pronounced in $S$. costatum. The umbilicus is, at a comparable diameter, narrower in $S$. costatum (ww $/ \mathrm{dm} \sim 0.40$ in S. costatum but $\sim 0.50$ in $S$. archiaci sp. nov.).

Sandbergeroceras archiaci sp. nov. urn:lsid:zoobank.org:act:CA8E6D62-FBEF-45A7-B4F9-2C914A45B54D

Fig 50A; Table 32

\section{Diagnosis}

Species of Sandbergeroceras with thinly discoidal, evolute conch at $30 \mathrm{~mm} \mathrm{dm}$ (ww/ $\mathrm{dm} \sim 0.35 ; \mathrm{uw} / \mathrm{dm}$ $\sim 0.50$ ). Whorl profile moderately depressed (ww/wh $\sim 1.55$ ); venter flatly rounded. Two deep spiral grooves on the venter. Shell ornament with 30 sigmoidal, sharp ribs on the flanks and coarse growth lines.

\section{Etymology}

Named after Étienne Jules Adolphe Desmier de Saint-Simon, Vicomte d'Archiac (1802-1868), one of the pioneers of studying fossils from the Red Ironstone.

\section{Material examined}

\section{Holotype}

GERMANY • Rhenish Mountains, Oberscheld (Grube Anna); early Frasnian (Red Ironstone); Koch Coll.; MB.C.3671.

\section{Description}

Holotype MB.C.3671 is an incomplete, but rather well-prerserved specimen of $33 \mathrm{~mm}$ conch diameter in fossil-rich and iron-rich limestone (Fig. 50A). It allows the study of slightly more than two whorls up to a conch diameter of $33 \mathrm{~mm}$. The conch is discoidal and evolute $(\mathrm{ww} / \mathrm{dm}=0.35 ; \mathrm{uw} / \mathrm{dm}=0.51)$ 
Table 32. Conch dimensions and ratios of selected specimen of Sandbergeroceras archiaci sp. nov.

\begin{tabular}{ccccccccccc}
\hline Specimen & $\mathbf{d m}$ & $\mathbf{w w}$ & $\mathbf{w h}$ & $\mathbf{u w}$ & $\mathbf{a h}$ & $\mathbf{w w} / \mathbf{d m}$ & $\mathbf{w w} / \mathbf{w h}$ & $\mathbf{u w} / \mathbf{d m}$ & WER & IZR \\
\hline MB.C. 3671 & 31.1 & 11 & 7.05 & 15.9 & 5.8 & 0.35 & 1.56 & 0.51 & 1.51 & 0.18 \\
\hline
\end{tabular}

with low coiling rate $(\mathrm{WER}=1.51)$; the whorl profile depressed ( $\mathrm{ww} / \mathrm{wh}=1.56)$ with continuously rounded umbilical wall, flanks and venter. The venter bears two rather deep spiral grooves. Both whorls bear rounded, forward-directed ribs; there are 30 such ribs on the last whorl and 40 on the penultimate. In addition, sharp growth lines are formed at almost equal intervals of about $0.2 \mathrm{~mm}$. They extend almost straight across the flank and curve forward to a moderately high projection in the ventrolateral area.

\section{Remarks}

Sandbergeroceras archiaci sp. nov. differs from $S$. tuberculosocostatum and $S$. costatum in the form of the whorl profile and the umbilical width. The whorl profile is rounded-triangular with a tightly rounded venter in the latter two species, whereas the venter is weakly flattened in $S$. costatum. The ventrolateral grooves are less pronounced in $S$. tuberculosocostatum and $S$. costatum. The umbilicus is, at $30 \mathrm{~mm}$ conch diameter, wider in $S$. costatum (ww $/ \mathrm{dm} \sim 0.50$ in $S$. costatum but only $\sim 0.40$ in S. tuberculosocostatum and S. costatum).

\section{Discussion}

The mining of the red ironstone of Dillenburg can be regarded as the cradle of the investigation of late Middle Devonian and early Late Devonian ammonoids. Already in the $19^{\text {th }}$ century (von Buch 1832; Beyrich 1837a; d'Archiac \& de Verneuil 1842; Sandberger \& Sandberger 1850-1856) and at the beginning of the $20^{\text {th }}$ century (Wedekind 1918), numerous species were described; however, the palaeontological study of these fossils experienced a long interruption thereafter, parallel to the slow decline of mining. Only with the study of time-equivalent assemblages from the Anti-Atlas of Morocco (Petter 1959; Bensaïd 1974; Bockwinkel et al. 2009, 2013a, 2015, 2017) and various localities in the Rhenish Mountains (Bockwinkel et al. 2013b; Bockwinkel \& Korn 2015, 2017) did awaken the interest in re-describing and revising the fossils from the original sites.

In a first step of the revision, we present here the redescription of the ammonoids from the suborder Pharciceratina. A total of 20 species are described. All belong to genera that are also known from other regions; the greatest similarity at the generic level is to the Anti-Atlas of Morocco. However, there is apparently no agreement concerning the species.

The species described here come from three stratigraphic intervals, in ascending order: (1) Maenioceras terebratum Zone (early Givetian; two species of Maenioceras), (2) Pseudoprobeloceras pernai Zone (latest Givetian; fifteen species belonging to the genera Pharciceras, Evopharciceras gen. nov., Extropharciceras, Lunupharciceras, Stenopharciceras, Synpharciceras and Pluripharciceras) and (3) Sandbergeroceras costatum Zone (early Frasnian; three species of Sandbergeroceras). They can therefore be easily correlated with occurrences in other regions, for example the Anti-Atlas.

\section{Acknowledgements}

We thank Doris Heidelberger (Wiesbaden), Alexander Gehler (Göttingen) and Ulrich Jansen (Frankfurt) for access to the palaeontological collections and Emmanuel Robert (Lyon) for information on the de Verneuil collection. We acknowledge Evelin Stenzel and Markus Brinkmann (Berlin) for the preparation as well as Jenny Huang and Clara Lembke (Berlin) for the photography of the specimens. We acknowledge the reviews by Kenneth De Baets (Erlangen) and David Work (Augusta). 


\section{References}

Aboussalam Z.S. \& Becker R.T. 2001. Prospects for an upper Givetian substage. Mitteilungen aus dem Museum für Naturkunde in Berlin, Geowissenschaftliche Reihe 4: 63-99. https://doi.org/10.1002/mmng.20010040107

Becher J.P. 1789. Mineralogische Beschreibung der Oranien-Nassauischen Lande nebst einer Geschichte des Siegenschen Hütten- und Hammerwesens. Neue Akademische Buchhandlung, Marburg.

Becker R.T. \& House M.R. 2000. Devonian ammonoid zones and their correlation with established series and stage boundaries. Courier Forschungsinstitut Senckenberg 220: 113-151.

Becker R.T., Aboussalam Z.S., Bockwinkel J., Ebbighausen V., El Hassani A. \& Nübel H. 2004. The Givetian and Frasnian at Oued Mzerreb (Tata region, eastern Dra Valley). Documents Institut scientifique, Rabat 19: 29-43.

Belka Z., Klug C., Kaufmann B., Korn D., Döring S., Feist R. \& Wendt J. 1999. Devonian conodont and ammonoid succession of the eastern Tafilalt (Ouidane Chebbi section), Anti-Atlas, Morocco. Acta Geologica Polonica 49: 1-23.

Bender P., Lippert H.-J. \& Nesbor H.-D. 1997. Blatt 5216 Oberscheld, 2. Auflage. Geologische Karte Hessen 1:25000 mit Erläuterungen: 1-421.

Bensaïd M. 1974. Étude sur des Goniatites à la limite du Dévonien moyen et supérieur, du Sud marocain. Notes du Service géologique du Maroc 36: 82-137.

Beyrich E. 1837a. Beiträge zur Kenntniss der Versteinerungen des Rheinischen Übergangsgebirges. Abhandlungen der Königlichen Akademie der Wissenschaften: 1-44.

Beyrich E. 1837b. De goniatitis in montibus rhenanis occurentibus. Academiae Regiae Scientiarum, Berrolini.

Beyrich E. 1884. Erläuterungen zu den Goniatiten L.v. Buch's. Zeitschrift der Deutschen Geologischen Gesellschaft 36: 203-219.

Bockwinkel J. \& Korn D. 2015. Late Givetian ammonoids from Oberberge (Middle Devonian; Rhenish Mountains). Neues Jahrbuch für Geologie und Paläontologie-Abhandlungen 278: 351-363.

https://doi.org/10.1127/njgpa/2015/0534

Bockwinkel J. \& Korn D. 2017. Late Givetian ammonoids from Iserlohn and Neuenrade (northern Rhenish Mountains). Neues Jahrbuch für Geologie und Paläontologie-Abhandlungen 286: 195-206. https://doi.org/10.1127/njgpa/2017/0695

Bockwinkel J., Becker R.T. \& Ebbighausen V. 2009. Upper Givetian ammonoids from Dar Kaoua (Tafilalt, SE Anti-Atlas, Morocco). Berliner paläobiologische Abhandlungen 10: 61-128.

Bockwinkel J., Becker R.T. \& Ebbighausen V. 2013a. Late Givetian ammonoids from Hassi Nebech (Tafilalt Basin, Anti-Atlas, southern Morocco). Fossil Record 16: 5-65.

https://doi.org/10.1002/mmng.201300001

Bockwinkel J., Korn D., Ebbighausen V. \& Graf S. 2013b. Late Givetian ammonoids from HagenHerbeck, Donnerkuhle quarry (Devonian, Rhenish Mountains). Neues Jahrbuch für Geologie und Paläontologie-Abhandlungen 270: 257-274. https://doi.org/10.1127/0077-7749/2013/0369

Bockwinkel J., Becker R.T. \& Ebbighausen V. 2015. Late Givetian ammonoids from Ait Ou Amar (northern Maider, Anti-Atlas, southeastern Morocco). Neues Jahrbuch für Geologie und Paläontologie, Abhandlungen 278: 123-158. https://doi.org/10.1127/njgpa/2015/0516 
Bockwinkel J., Becker R.T. \& Aboussalam Z.S. 2017. Ammonoids from the late Givetian Taouzites Bed of Ouidane Chebbi (eastern Tafilalt, SE Morocco). Neues Jahrbuch für Geologie und Paläontologie, Abhandlungen 284 307-354. https://doi.org/10.1127/njgpa/2017/0664

Bogoslovsky B.I. 1955. O semeystve Pharciceratidae Hyatt, 1900. Doklady Akademiya Nauk SSSR 103 (6): 1103-1106.

Bogoslovsky B.I. 1969. Devonskie ammonoidei. I. Agoniatity. Trudy Paleontologicheskogo Instituta Akademiya Nauk SSSR 124: 1-341.

d'Archiac V. \& de Verneuil M.E. 1842. On the fossils of the older deposits in the Rhenish Provinces; preceded by a general survey of the fauna of the Palaeozoic rocks, and followed by a tabular list of the organic remains of the Devonian. Transactions of the Geological Society of London (2) 6: 303-410. https://doi.org/10.1144/transgslb.6.2.303

Drevermann F. 1903. Ueber Triaenoceras costatum A.V. sp. Zeitschrift der Deutschen Geologischen Gesellschaft 55: 85-92.

Foord A.H. \& Crick G.C. 1897. Catalogue of the Fossil Cephalopoda in the British Museum (Natural History), Part III, Containing the Bactritidae and Part of the Suborder Ammonoidea. Printed by order of the Trustees, London.

Frech F. 1888. Geologie der Umgebung von Haiger bei Dillenburg (Nassau). Abhandlungen der Königlich Preußischen Geologischen Landesanstalt 8: 223-258.

Frech F. 1897-1902. Lethaea geognostica oder Beschreibung und Abbildung der für die GebirgsFormationen bezeichnendsten Versteinerungen. I. Theil. Lethaea palaeozoica. 2. Band. Schweizerbart, Stuttgart. https://doi.org/10.5962/bhl.title.25536

Frech F. 1902. Über devonische Ammoneen. Beiträge zur Paläontologie Österreich-Ungarns und des Orients 14: 27-112.

Frohwein E. 1885. Beschreibung des Bergreviers Dillenburg. A. Marcus.

Georg R., Haus R. \& Porezag K. 1985. Eisenerzbergbau in Hessen. Förderverein Besucherbergwerk Fortuna, Wetzlar.

Göddertz B. 1987. Devonische Goniatiten aus SW-Algerien und ihre stratigraphische Einordnung in die Conodonten-Abfolge. Palaeontographica Abteilung A 197: 127-220.

Harbort E. 1903. Zur Frage der Entstehung gewisser devonischer Roteisensteinlagerstätten. Neues Jahrbuch für Mineralogie, Geologie und Paläontologie 1903: 179-192.

Holzapfel E. 1889. Die Cephalopoden-führenden Kalke des unteren Carbon von Erdbach-Breitscheid bei Herborn. Palaeontologische Abhandlungen, Neue Folge 5: 1-74.

Holzapfel E. 1895. Das Obere Miteldevon (Schichten mit Stringocephalus Burtini und Maeneceras terebratum) im Rheinischen Gebirge. Abhandlungen der Königlich Preussischen geologischen Landesanstalt, Neue Folge 16: 1-460.

House M.R. 1971. The goniatite wrinkle-layer. Smithsonian Contributions to Paleontology 3: 23-32.

House M.R. \& Ziegler W. 1977. The goniatite and conodont sequences in the early Upper Devonian at Adorf, Germany. Geologica et Palaeontologica 11: 69-108.

Hyatt A. 1883-1884. Genera of fossil cephalopods. Proceedings of the Boston Society of Natural History 22: $253-338$. 
International Commission of Zoological Nomenclature 1956. Opinion 392. Emendation to "Sandbergeroceras" of the genetic name "Sandbergeoceras" Hyatt, 1884 (Class Cephalopoda, Order Ammonoidea). The Bulletin of Zoological Nomenclature 12: 297-304.

Jockenhövel A. \& Willms C. 1993. Auf den Spuren alter Eisenhüttenleute an der oberen Dill. Archäologische Denkmäler in Hessen 122: 1-16.

Kayser E. 1907a. Erläuterungen zu Blatt Dillenburg. Geologische Karte von Preußen und benachbarten Bundesstaaten 1:25000 Lieferung 101: 1-119.

Kayser E. 1907b. Erläuterungen zu Blatt Oberscheld. Geologische Karte von Preußen und benachbarten Bundesstaaten 1:25000 Lieferung 101: 1-127.

Kegel W. 1934a. Die geologischen Grundlagen des Roteisensteinbergbaus im Dillgebiet. Zeitschrift der Deutschen Geologischen Gesellschaft 86: 314-324.

Kegel W. 1934b. Geologie der Dillmulde. Abhandlunger der Preußischen Geologischen Landesanstalt, Neue Folge 160: 1-48.

Kegel W. 1934c. Über das Oberdevon auf dem Nordflügel der Dillmulde. Jahrbuch der Preußischen Geologischen Landesanstalt 54: 531-545.

Klug C. \& Korn D. 2002. Occluded umbilicus in the Pinacitinae (Devonian) and its palaeoecological implications. Palaeontology 45: 917-931. https://doi.org/10.1111/1475-4983.00268

Klug C., Korn D., Landman N.H., Tanabe K., De Baets K. \& Naglik C. 2015. Describing ammonoid conchs. In: Klug C., Korn D., De Baets K., Kruta I. \& Mapes R.H. (eds) Ammonoid Paleobiology: from Macroevolution to Paleogeography, Topics in Geobiology 44: 3-24. Springer, Dordrecht. https://doi.org/10.1007/978-94-017-9630-9_1

Koch C. 1858. Paläozoische Schichten und Grünsteine in den Herzoglich Nassauischen Ämtern Dillenburg und Herborn unter Berücksichtigung allgemeiner Lagerungsverhältnisse in angränzenden Länderteilen. Jahrbücher des Vereins für Naturkunde im Herzogthum Nassau 13: 85-329.

Korn D. 1999. Septal projections - a method for the illustration of septa in early ammonoids. In: Rozanov A.Y. \& Shevyrev A.A. (eds) Fossil Cephalopods: Recent Advances in Their Study, Paleontologicheskogo Instituta Rossiyskaya Akademiya Nauk: 62-67. Russian Academy of Sciences, Moscow.

Korn D. 2010. A key for the description of Palaeozoic ammonoids. Fossil Record 13: 5-12. https://doi.org/10.1002/mmng.200900008

Korn D. \& Klug C. 2002. Ammoneae Devonicae. Backhuys, Leiden.

Krebs W. 1959a. Zur Feinstratigraphie der Adorf-Stufe bei Dillenburg. Zeitschrift der Deutschen Geologischen Gesellschaft 111: 233-234. https://doi.org/10.1127/zdgg/111/1959/233

Krebs W. 1959b. Zur Grenze Mittel-/Ober-Devon und zur Gliederung des obersten Mittel-Devons und der tieferen Adorf-Stufe nach Conodonten. Senckenbergiana 40: 367-387.

Krebs W. 1960. Stratigraphie, Vulkanismus und Fazies des Oberdevons zwischen Donsbach und Hirzenhain (Rheinisches Schiefergebirge, Dill-Mulde). Abhandlungen des Hessischen Landesamtes für Bodenforschung 33: 1-119.

Krebs W. \& Rabien A. 1964. Zur Biostratigraphie und Fazies der Adorf-Stufe bei Donsbach. Notizblatt des Hessischen Landesamtes für Bodenforschung 92: 75-119. 
Kullmann J. \& Ziegler W. 1970. Conodonten und Goniatiten von der Grenze Mittel-/Oberdevon aus dem Profil am Martenberg (Ostrand des Rheinischen Schiefergebirges). Geologica et Palaeontologica 4: $73-85$.

Lippert H.-J., Hentschel H. \& Rabien A. 1970. Erläuterungen zu Blatt 5215 Dillenburg. 2. neu bearbeitete Auflage. Geologische Karte von Hessen 1.25000 5215: 1-550.

Lotz H. 1902. Die Dillenburger Rot-und Magneteisenerze. Zeitschrift der Deutschen Geologischen Gesellschaft 54: 139-141.

Matern H. 1931. Das Oberdevon der Dill-Mulde. Abhandlungen der Preußischen Geologischen Landesanstalt, Neue Folge 134: 1-139.

Miller A.K. 1938. Devonian ammonoids of America. Special Papers of the Geological Society of America 14: 1-262. https://doi.org/10.1130/SPE14-p1

Miller A.K. 1952. Proposed acceptance of the emendation to "Sandbergeroceras" of the genetic name "Sandbergeoceras" Hyatt, 1884 (Class Cephalopoda, Order Ammonoidea); and the establishment of "Goniatites tuberculosocostatus" G. and F. Sandberger, 1850, as its type species. The Bulletin of Zoological Nomenclature 6: 357-358. https://doi.org/10.5962/bhl.part.16067

Petter G. 1959. Goniatites dévoniennes du Sahara. Publications du Service de la Carte géologique de l'Algérie (nouvelle série), Paléontologie 2: 1-313.

Sandberger G. \& Sandberger F. 1850-1856. Die Versteinerungen des rheinischen Schichtensystems in Nassau. Mit einer kurzgefassten Geognosie dieses Gebietes und mit steter Berücksichtigung analoger Schichten anderer Länder. Kreidel \& Niedner, Wiesbaden. https://doi.org/10.5962/bhl.title.52349

Schindewolf O.H. 1940. "Konvergenzen" bei Korallen und Ammoneen. Fortschritte der Geologie, Paläontologie 1241: 389-492.

Stoppel D. 1988. Auf Erzsuche: zur Geschichte des Silber-, Kupfer-und Schwerspatbergbaus im Raum Biedenkopf-Dillenburg. Bode, Salzhemmendorf.

Termier G. \& Termier H. 1950. Paléontologie Marocaine. II. Invertébrés de l'ére Primaire. Fascicule III. Mollusques. Notes et mémoires, Service géologique, Protectorat de la République française au Maroc, Direction de la Production industrielle et des Mines, Division des Mines et de la Géologie Republique française Maroc 78: 1-246.

Tietze E. 1869. Ueber die devonischen Schichten von Ebersdorf unweit Neurode in der Grafschaft Glatz: 43. Geognostische Inaugual-Dissertation, Philosophische Facultät. Universität Breslau, Breslau.

Tietze E. 1871. Ueber die devonischen Schichten von Ebersdorf unweit Neurode in der Grafschaft Glatz. Palaeontographica 19: 103-158.

von Buch L. 1832. Über Goniatiten. Physikalische Abhandlungen der Königlichen Akademie der Wissenschaften Berlin 1832: 159-187.

Walliser O.H. 1970. Über die Runzelschicht bei Ammonoidea. Göttinger Arbeiten zur Geologie/ Paläontologie (H. Martin-Festschrift) 5: 115-126.

Walliser O.H., Bultynck P. \& Weddige K. 1995. Definition of the Eifelian-Givetian Stage boundary. Episodes 18: 107-115. https://doi.org/10.18814/epiiugs/1995/v18i3/002

Wedekind R. 1918. Die Genera der Palaeoammonoidea (Goniatiten). Mit Ausschluß der Mimoceratidae, Glyphioceratidae und Prolecanitidae. Palaeontographica 62: 85-184. 
Wissner U. \& Norris A. 1991. Middle Devonian goniatites from the Dunedin and Besa River formations of northeastern British Columbia. In: Contributions to Canadian Paleontology, Bulletin of the Geological Survey Canada 412: 45-79. https://doi.org/10.4095/132679

Manuscript received: 18 April 2021

Manuscript accepted: 16 July 2021

Published on: 23 September 2021

Topic editor: Christian de Muizon

Desk editor: Kristiaan Hoedemakers

Printed versions of all papers are also deposited in the libraries of the institutes that are members of the EJT consortium: Muséum national d'histoire naturelle, Paris, France; Meise Botanic Garden, Belgium; Royal Museum for Central Africa, Tervuren, Belgium; Royal Belgian Institute of Natural Sciences, Brussels, Belgium; Natural History Museum of Denmark, Copenhagen, Denmark; Naturalis Biodiversity Center, Leiden, the Netherlands; Museo Nacional de Ciencias Naturales-CSIC, Madrid, Spain; Real Jardín Botánico de Madrid CSIC, Spain; Zoological Research Museum Alexander Koenig, Bonn, Germany; National Museum, Prague, Czech Republic. 